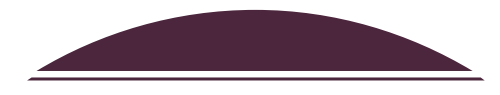

LATVIJAS BANKA

ISBN 978-9984-888-80-4

EIROSISTE MA

ELENA BOBEICA

STYLIANI CHRISTODOULOPOULOU

OL,EGS TKAČEVS

\title{
THE ROLE OF PRICE AND COST COMPETITIVENESS FOR INTRA- AND EXTRA-EURO AREA TRADE OF EURO AREA COUNTRIES
}




\section{CONTENTS}

ABSTRACT 3

NON-TECHNICAL SUMMARY 4

1. INTRODUCTION 5

2. LITERATURE REVIEW

3. STYLISED FACTS 9

4. DATA AND METHODOLOGY DESCRIPTION 15

5. EMPIRICAL FINDINGS 17

CONCLUSIONS 25

APPENDIX 26

REFERENCES $\quad 41$

ADF test - Augmented Dickey-Fuller test

AWM - Euro Area-Wide Model

CPI - consumer price index

ECB - European Central Bank

ECM - Error Correction Model

EU - European Union

FDI - foreign direct investment

G7 countries - Canada, France, Germany, Italy, Japan, the United Kingdom, and the United States

GDP - gross domestic product

$\mathrm{HCI}$ - harmonised competitiveness indicator

KPSS test - Kwiatkowski-Phillips-Schmidt-Shin test

NEER - nominal effective exchange rate

PPI - domestic sales producer price index

REER - real effective exchange rate

SITC Rev. 3 - Standard International Trade Classification, Rev. 3

ULC - unit labour costs

ULCM - unit labour costs in manufacturing

ULCT - unit labour costs in total economy 


\section{ABSTRACT}

This paper studies the importance of price and cost competitiveness for intra- and extra-euro area trade flows of euro area countries. A standard error correction framework shows that price competitiveness is a relatively more important driver of trade flows outside the euro area as compared to those within the monetary union, especially for exports, that tend to be more sensitive to relative prices than imports. We consider various measures of competitiveness and conclude that it is difficult to single out one that outperforms the others. Using an encompassing test, measures based on labour costs appear to contain relatively more information for trade flows, particularly for exports outside the euro area.

The key policy implication is that, in order to adjust competitiveness disequilibria within the monetary union, measures, such as structural policies fostering non-price competitiveness should be pursued in the deficit countries besides those aimed at price and cost adjustments.

Keywords: price and cost competitiveness, intra- and extra-euro area trade, error correction model

JEL codes: F14, F15, F41

We would like to thank the participants of the COMPNET meeting in Banco de España held from 25 to 27 March 2015 in Madrid for very useful comments. Also, we would like to thank Chiara Osbat (ECB), Kostantīns Beņkovskis (Latvijas Banka) and an anonymous referee for their useful suggestions and comments. Any errors or omissions are exclusively our own responsibility. E-mail addresses: Elena.Bobeica@ecb.europa.eu; Styliani.Christodoulopoulou@ecb.europa.eu; Olegs.Tkacevs@bank.lv.

Notes: This Working Paper should not be reported as representing the views of the European Central Bank (ECB) or Latvijas Banka. The views expressed here are those of the authors and do not necessarily reflect those of the ECB or Latvijas Banka. 


\section{NON-TECHNICAL SUMMARY}

Since restoring price competitiveness is usually regarded as essential in external rebalancing of euro area countries, we seek to uncover the impact of cost and price competitiveness on goods trade flows of individual euro area countries, distinguishing between trade within and outside the euro area. We estimate standard export and import equations over the sample period from the first quarter of 1995 to the third quarter of 2013 where five different price and cost competitiveness measures are considered in turn as one of the explanatory variables. These five indicators are based on consumer price index (CPI), domestic sales producer price index (PPI), gross domestic product (GDP) deflator, as well as unit labour costs in manufacturing (ULCM) and total economy (ULCT).

The estimation of intra- and extra-euro area export equations illustrates that price competitiveness seems to be a relatively more important driver of exports outside the euro area than within the monetary union, as indicated by the larger number of specifications for which extra-euro area exports are found to be sensitive to price competitiveness. However, where significant, the magnitude of price competitiveness effect is larger for intra-euro area exports. Furthermore, when employing a shorter pre-crisis sample ending with the first quarter of 2008, the number of specifications where price competitiveness appears significant for intra-euro area exports is larger as compared to the full sample, pointing out that the global financial crisis may have distorted a standard relationship between exports and relative prices within the euro area.

For imports, price competitiveness plays a less significant role compared to exports (even after accounting for energy imports) due to the increasing integration of the euro area countries in global value chains. The number of specifications for which imports are sensitive to price competitiveness is found to be larger for extra-euro area imports (especially when imports net of energy or the sample ending at the onset of the crisis are considered).

Based on the significance of various measures of price and cost competitiveness, it is difficult to single out one particular measure that outperforms the others. A widely used statistical test is employed to judge which price competitiveness indicator is superior in explaining exports and imports. This test suggests that the indicators based on relative labour costs (in particular ULCM-based) have higher information content for trade flows, in particular exports outside the euro area. Broad price-based competitiveness indicators (namely CPI, GDP deflator and ULCT) appear superior in the case of intra-euro area exports.

The study also performs a few robustness checks. Inter alia, these include the possible effect of domestic demand on exports and employ alternative domestic demand measures accounting for their imports content. Additionally, for imports, we test the sensitivity of our results based on imports excluding energy. The robustness analysis confirms the main findings of the study.

Our main policy conclusion rests on the results that relative prices and costs play an important role for trade flows to countries outside the euro area, whereas relative price and cost adjustment has more limited effects on the rebalancing process within the euro area. This suggests that additional measures, such as structural reforms, including those in domestic product and labour markets and those driving non-price competitiveness, should be pursued in the deficit countries besides those aiming at price and cost adjustment. 


\section{INTRODUCTION}

External imbalances faced by some euro area members have triggered an intense discussion of the problem of restoring competitiveness through cost/price adjustment. It is thus important to assess exactly how much of the gain in price/cost competitiveness translates into an increase in exports and a reduction in imports. While most studies so far have focused on total trade, the present study distinguishes between intra- and extraeuro area trade, i.e. trade within the euro area and with the rest of the world. Markets inside and outside the euro area are different with respect to competitive pressures, tastes of consumers, degree of product differentiation, etc. All these point to the fact that the effect of price competitiveness is likely to differ in the case of trade inside and outside the euro area.

Euro area countries are a special case in the sense that approximately half of their trade occurs within the currency union, where price competitiveness can be restored only through a painful internal devaluation or by sharing the effort with countries willing to accept higher inflation. In a situation of a strong euro appreciation, the effort that member states have to undertake to regain price competitiveness within the currency union is even higher, as the nominal appreciation will exert downward inflationary pressures also in surplus countries. Furthermore, in these surplus countries, economic agents acting in a competitive environment may change prices in relationship to those of foreign competitors by adjusting mark-ups, which makes the achievement of price competitiveness gains even harder.

From a theoretical point of view, it is not straightforward a priori whether the adoption of the common currency would act in the direction of an increased impact of price differential on trade or, on the contrary, would imply a less important role of price and cost competitiveness indicators. On the one hand, being part of the currency union can generate a boost in commercial linkages (Frankel and Rose (1998)), and the euro area has exhibited increased commercial integration since the launch of the euro. Blanchard and Giavazzi (2002) show that integration in the goods market has led to an increase in the elasticity of demand for each good. Also, the ECB (2013) shows that the sectoral breakdown of exports is relatively similar across euro area countries, and this similarity has gradually increased since the inception of the euro. If goods traded within the euro area are similar to each other, in other words substitutable, this could raise the impact of price differentials on trade within the monetary union.

On the other hand, competitive pressures on markets outside the euro area are likely to be stronger possibly due to relatively cheaper local producers or a more prominent presence of exporters from emerging markets. This could act in the direction of higher trade sensitivity to relative price changes for sales outside the euro area. The difference between intra- and extra-euro area trade elasticity to price and cost competitiveness indicators is ultimately an empirical problem.

The purpose of this paper is twofold. First, it provides empirical evidence on the importance of relative prices for intra- and extra-euro area trade flows. We estimate intra- and extra-euro area export and import equations for each euro area country in order to assess the price sensitivity of underlying trade flows within a country-specific setting, given that each country exhibits particularities in terms of the export basket, market diversification, integration with the rest of the euro area, etc. Second, it considers various measures of price/cost competitiveness to investigate whether there is a particular indicator that outperforms the others in terms of relevance for trade flows. To 
our knowledge, this is the first attempt so far to examine determinants of intra- and extra-euro area exports and imports on a cross-country basis.

The results suggest that price competitiveness seems to be a relatively more important driver for exports outside the euro area than for exports within the monetary union. Regarding the former, we find that real appreciation of the euro against the currencies of its main trading partners appears to have a substantial negative effect on exports of most of the euro area countries in the long run, whereas the immediate effect appears to be relatively less important. For imports, the relative prices/costs play a less significant role compared to exports (even after accounting for energy imports), also in line with the findings of Christodoulopoulou and Tkačevs (2016) for aggregate trade. The global financial crisis appears to have distorted the standard relationship between exports and relative prices within the euro area and to have impacted the relationship between imports and price competitiveness.

The statistical encompassing test, performed to judge which harmonised competitiveness indicator (henceforth, $\mathrm{HCI}$ ) is superior in explaining import and export patterns, indicates that indicators of cost competitiveness and even more so ULCMbased HCIs appear to contain some extra information for trade flows as compared to the other considered measures. This holds true especially in the case of extra-euro area exports. On the other hand, in the case of intra-euro area exports, broad price-based HCIs (namely, CPI, GDP deflator and ULCT) appear as "best", indicating the need for broad structural reforms to moderate costs, since intra-euro area exports cannot benefit from euro nominal depreciation to the same extent as extra-euro area exports. The results of previous studies comparing performance of different HCI measures in explaining trade flows are mixed (Marsh and Tokarick (1996), Clostermann (1998), Ca' Zorzi and Schnatz (2007)). However, these studies do not distinguish between extraand intra-area flows in contrast to the present one.

The key policy implication of the paper rests on the main empirical finding that relative prices play an important role for trade flows to countries outside the euro area, whereas relative price adjustment has more limited effects on the rebalancing process within the euro area. This suggests that in order to adjust competitiveness disequilibria within the monetary union, additional measures, such as structural reforms with an impact on productivity and more generally on non-price competitiveness, should be pursued in the deficit countries besides those aiming at price and cost adjustment. At the European level, policy makers have been stressing the importance of structural reforms that would boost potential growth through improved functioning of labour and product markets and promotion of scientific and technological progress (see European Commission (2015)). Also, recent studies on drivers of competitiveness emphasise the fundamental role of productivity for the ability of firms to export and the role of optimum allocation of resources through tailored policies (Lopez-Garcia and di Mauro (2015)).

The remainder of the paper is structured as follows. Section 2 reviews the related literature. Section 3 presents the main stylised facts regarding intra- and extra-euro area trade patterns of individual euro area countries as well price and cost competitiveness developments. Section 4 describes the data and methodology used in the study. Section 5 provides the estimation results of intra- and extra-euro area export and import equations respectively. Section 6 concludes. 


\section{LITERATURE REVIEW}

There is a vast literature dealing with euro area export and import performance. However, most likely due to data constraints, there is a limited number of studies analysing euro area trade inside and outside the monetary union (see Table A1 in Appendix for a short summary of findings). Furthermore, the results of the empirical literature appear to be very much sample, country and model dependent. The absolute magnitude of export and import elasticity with respect to price/cost competitiveness is mostly found to lie between 0 and 1, both on the aggregate level and when trade is broken down by destination ${ }^{1}$.

The relatively scarce literature on intra- versus extra-euro area dimension of exports contains some evidence of intra-euro area export flows being more sensitive to relative price movements. Stahn (2006) showed that in the case of Germany intra-euro area exports exhibit higher sensitivity to price competitiveness (elasticity of 0.9 ) than extra-euro area exports (elasticity of 0.6) over a long sample starting in 1980. A higher price elasticity of intra- as compared to extra-euro area exports is also documented by Pluyaud (2006) in the case of France (0.9 versus 0.5). Bayoumi et al. (2011) find that intra-euro area exports of a panel of 11 euro area countries are far more sensitive to price competitiveness than extra-euro area exports, and this difference has increased since the inception of the EMU due to increased integration and smaller exchange rate variability. On the other hand, Stahn (2006) shows that while the effect of price competitiveness on German exports is significant in the sample starting in 1980, it appears to be much less important in a shorter sample (starting in 1993). Lower sensitivity in the more recent period is ascribed to the shift in favour of less priceelastic export products (e.g. capital products) in the German export structure. Another explanation is a change in the pricing behaviour of German exporters who are better prepared to adjust their margins as prices change. Not all studies point to a higher intra-euro area price elasticity of exports. Estrada et al. (2004) estimate the relative price elasticity of Spanish exports to the euro area to be somewhat lower as compared to exports to third countries.

Regarding imports, some studies have shown that extra-euro area imports appear to be somewhat inelastic to relative prices when comprising energy items, whereas price elasticities of extra-euro area imports appear comparable to intra-euro area ones when the former excludes imports of energy. Among these studies, Stirböck (2006) eliminates energy imports from extra-euro area imports and finds for the case of Germany that relative prices appear significant for intra-euro area imports only. The magnitude of intra-euro area import price elasticity was found to have increased (1.3 in a more recent sample versus 0.7 over a longer sample), due to somewhat stronger price competition after the creation of the monetary union. In the case of France, Pluyaud (2006) estimates relative price elasticities of both intra-euro area imports and extra-euro area non-energy imports to be high (2.2 and 1.7 respectively when demand elasticity is restricted to be equal to unity, and 0.7 and 0.8 respectively when demand elasticity is not restricted). Extra-euro area energy imports appear to be insensitive to relative prices. Relative price elasticities of Spanish imports, estimated by Estrada et al. (2004) within the framework of a macro econometric model, are somewhat lower: 0.52 for intra- and 0.48 for extra-euro area imports respectively ${ }^{2}$.

\footnotetext{
${ }^{1}$ Studies employing firm-level data usually find these elasticities to be above 1 (see Berthou et al. (2015)).

${ }^{2}$ Developments in oil prices are controlled for in extra euro area import equations.
} 
Anderton et al. (2005) and Dieppe and Warmedinger (2007) provide an alternative way of looking at the reaction of imports to relative price developments by incorporating a substitution effect between intra- and extra-euro area imports. Dieppe and Warmedinger (2007) use various simulations within the ECB's Euro Area-Wide Model (AWM) and show that at least over the first two years after a nominal appreciation of the euro, euro area total imports tend to be below the baseline. This reflects the substitution effect away from intra-euro area imports to extra-euro area imports, complemented by a lower domestic activity effect from currency appreciation. This drop in imports, in contrast to what economic theory would predict, is ascribed to a high import content of exports with the latter having the tendency to shrink after a nominal appreciation. Anderton et al. (2005) also found evidence of substitution between intra- and extra-euro area imports due to a change in their relative price levels. Furthermore, they explicitly introduce a term capturing exchange rate volatility into import equations that is found to shift trade towards lower-volatility regions. Hence, the launch of the euro, by eliminating exchange rate volatility within the monetary union, should have increased intra-euro area imports by substituting away from extra-euro area imports ${ }^{3}$.

Only a minor number of studies compare the impact of alternative measures of cost and price competitiveness on exports/imports. Bayoumi et al. (2011) explore the differences in elasticities among various competitiveness indicators and conclude that real effective exchange rates (REER) using as deflators wholesale price indices (WPI), export unit values (XUV) and unit labour costs in manufacturing (ULCM), outperform CPI-based ones in terms of their statistical significance. This finding applies to both intra- and extra-euro area exports. Marsh and Tockarick (1996), Clostermann (1998) and Ca' Zorzi and Schnatz (2007) apply a more formal test to see which competitiveness indicator is more relevant in explaining export flows (though they ignore the intra- versus extra-euro area dimension). They all employ an in-sample performance test, whereby they include two (or several) alternative HCIs and gauge their information content relative to each other. Marsh and Tokarick (1996) and Ca' Zorzi and Schnatz (2007) do not give priority to any of the competitiveness indicators in their studies of exports in the G7 countries and euro area respectively. On the other hand, indicators based on broad price measures (CPI and total expenditure deflator) are found superior to others in Clostermann (1998) for the case of the German exports.

\footnotetext{
${ }^{3}$ ECB (2013) suggests that other factors, such as the rise of China and other emerging markets and an increase in participation in global value chains have dominated the trade patterns.
} 


\section{STYLISED FACTS}

This section presents the main stylised facts regarding intra- and extra-euro area trade patterns and trade balances of individual euro area countries, as well as price competitiveness developments based on various relative price and cost measures. It disentangles the role of intra- versus extra-euro area trade in current account adjustments in the euro area and discusses the importance of price competitiveness in this regard.

Intra- and extra-euro area trade account for almost half of euro area trade volume each, but their relative importance varies considerably among individual euro area countries. As shown in Tables 1 and 2, extra-euro area trade in goods is particularly important for countries that are geographically closer to non-euro area countries, in particular for Finland, Estonia, Ireland, Latvia and Greece. This also holds for Germany, which managed to gain substantially from the rise of emerging markets and their growing demand for German capital goods, and Italy owing to its growing trade with the new EU Member States in terms of intermediate goods ${ }^{4}$. Due to their proximity to non-euro area countries, Malta and Cyprus exported mostly to trading partners outside the euro area, while their share of imports from outside the euro area declined over time.

The share of intra-euro area exports and imports has declined in most euro area member states since the beginning of the 2000s (Tables 1 and 2$)^{5}$. As a result, in more than half of the euro area countries this share fell below $50 \%$ by 2013 . This trend is predominantly evident since the 2007-2008 financial crisis, as the drop in intra-euro area export and import shares tends to be larger than that prior to the crisis. On the other hand, countries such as Estonia, Slovenia and Slovakia exhibited a large drop in intra-euro area export shares prior to the crisis, which might be related to a marked rise in their relative prices/costs compared to their intra-euro area partners, as discussed below.

Trade with non-euro area countries has been more dynamic in the aftermath of the international financial crisis, spurred by robust economic growth of emerging markets and their relatively higher resilience to economic turbulences during the crisis. The fall in output observed in the euro area since the onset of the economic crisis and the associated collapse in imports led many euro area member states to seek alternative markets for their products outside the euro area, implying a shift in the pattern of external trade towards third countries.

\footnotetext{
${ }^{4}$ Italy, together with Germany, has been largely involved in the emergence of international production networks in Central and Eastern Europe, mainly in intermediate goods. Trade within supply chains may have proved more resilient during the crisis. See for details Altomonte and Ottaviano (2009). Also, since the crisis Italian export growth has been mainly benefited by the demand from the rest of the world in relative terms (see Tressel and Wang (2014)).

${ }^{5}$ See also ECB (2012).
} 
Table 1

Intra- and extra-euro area exports of goods (percent of total exports)

\begin{tabular}{|c|c|c|c|c|c|c|c|c|}
\hline \multirow[t]{2}{*}{ Country } & \multicolumn{2}{|c|}{2000} & \multicolumn{2}{|c|}{2007} & \multicolumn{2}{|c|}{2013} & \multicolumn{2}{|c|}{ Intra-euro area exports } \\
\hline & $\begin{array}{r}\text { intra-euro } \\
\text { area exports }\end{array}$ & $\begin{array}{r}\text { extra-euro } \\
\text { area exports }\end{array}$ & $\begin{array}{r}\text { intra-euro } \\
\text { area exports }\end{array}$ & $\begin{array}{r}\text { extra-euro } \\
\text { area exports }\end{array}$ & $\begin{array}{r}\text { intra-euro } \\
\text { area exports }\end{array}$ & $\begin{array}{r}\text { extra-euro } \\
\text { area exports }\end{array}$ & $\begin{array}{r}2007 \text { vs } \\
2000\end{array}$ & $\begin{array}{r}2013 \text { vs } \\
2007\end{array}$ \\
\hline Austria & 58.1 & 41.9 & 54.6 & 45.4 & 53.1 & 46.9 & -3.5 & -1.5 \\
\hline Belgium & 62.5 & 37.5 & 62.8 & 37.2 & 56.8 & 43.2 & 0.3 & -6.0 \\
\hline Cyprus & 35.0 & 65.0 & 51.1 & 48.9 & 38.7 & 61.3 & 16.1 & -12.4 \\
\hline Germany & 45.5 & 54.5 & 43.8 & 56.2 & 36.8 & 63.2 & -1.6 & -7.1 \\
\hline Estonia & 48.6 & 51.4 & 31.5 & 68.5 & 30.7 & 69.3 & -17.1 & -0.8 \\
\hline Spain & 61.1 & 38.9 & 57.8 & 42.2 & 50.4 & 49.6 & -3.3 & -7.4 \\
\hline Finland & 38.3 & 61.7 & 32.8 & 67.2 & 31.2 & 68.8 & -5.5 & -1.6 \\
\hline France & 50.9 & 49.1 & 51.3 & 48.7 & 46.6 & 53.4 & 0.4 & -4.7 \\
\hline Greece & 44.6 & 55.4 & 43.5 & 56.5 & 32.0 & 68.0 & -1.1 & -11.5 \\
\hline Ireland & 40.6 & 59.4 & 41.2 & 58.8 & 36.8 & 63.2 & 0.6 & -4.4 \\
\hline Italy & 48.4 & 51.6 & 46.3 & 53.7 & 39.9 & 60.1 & -2.1 & -6.4 \\
\hline Luxembourg & 74.4 & 25.6 & 70.9 & 29.1 & 73.5 & 26.5 & -3.5 & 2.6 \\
\hline Latvia & 36.9 & 63.1 & 35.3 & 64.7 & 30.6 & 69.4 & -1.6 & -4.7 \\
\hline Malta & 25.8 & 74.2 & 32.7 & 67.3 & 33.8 & 66.2 & 6.9 & 1.1 \\
\hline Netherlands & 64.5 & 35.5 & 61.1 & 38.9 & 59.4 & 40.6 & -3.3 & -1.7 \\
\hline Portugal & 66.7 & 33.3 & 67.0 & 33.0 & 60.3 & 39.7 & 0.3 & -6.7 \\
\hline Slovenia & 61.0 & 39.0 & 52.0 & 48.0 & 52.3 & 47.7 & -9.0 & 0.2 \\
\hline Slovakia & 57.1 & 42.9 & 51.1 & 48.9 & 44.3 & 55.7 & -6.0 & -6.8 \\
\hline
\end{tabular}

Sources: Eurostat and authors' calculations.

Table 2

Intra- and extra-euro area imports of goods (percent of total imports)

\begin{tabular}{|c|c|c|c|c|c|c|c|c|}
\hline \multirow[t]{2}{*}{ Country } & \multicolumn{2}{|c|}{2000} & \multicolumn{2}{|c|}{2007} & \multicolumn{2}{|c|}{2013} & \multicolumn{2}{|c|}{ Intra-euro area imports } \\
\hline & $\begin{array}{r}\text { intra-euro } \\
\text { area imports } \\
\end{array}$ & $\begin{array}{r}\text { extra-euro } \\
\text { area imports }\end{array}$ & $\begin{array}{r}\text { intra-euro } \\
\text { area imports } \\
\end{array}$ & $\begin{array}{r}\text { extra-euro } \\
\text { area imports }\end{array}$ & $\begin{array}{r}\text { intra-euro } \\
\text { area imports }\end{array}$ & $\begin{array}{r}\text { extra-euro } \\
\text { area imports }\end{array}$ & $\begin{array}{r}2007 \text { vs } \\
2000 \\
\end{array}$ & 2013 vs 2007 \\
\hline Austria & 67.0 & 33.0 & 68.0 & 32.0 & 63.4 & 36.6 & 1.1 & -4.6 \\
\hline Belgium & 57.5 & 42.5 & 59.3 & 40.7 & 55.9 & 44.1 & 1.8 & -3.5 \\
\hline Cyprus & 44.8 & 55.2 & 55.3 & 44.7 & 59.8 & 40.2 & 10.5 & 4.5 \\
\hline Germany & 45.5 & 54.5 & 45.8 & 54.2 & 44.8 & 55.2 & 0.3 & -1.1 \\
\hline Estonia & 48.6 & 51.4 & 41.7 & 58.3 & 37.6 & 62.4 & -6.8 & -4.1 \\
\hline Spain & 56.9 & 43.1 & 53.1 & 46.9 & 45.6 & 54.4 & -3.8 & -7.5 \\
\hline Finland & 39.2 & 60.8 & 38.6 & 61.4 & 38.2 & 61.8 & -0.6 & -0.4 \\
\hline France & 55.6 & 44.4 & 58.3 & 41.7 & 56.6 & 43.4 & 2.7 & -1.7 \\
\hline Greece & 52.4 & 47.6 & 48.2 & 51.8 & 36.6 & 63.4 & -4.2 & -11.6 \\
\hline Ireland & 26.3 & 73.7 & 28.1 & 71.9 & 27.3 & 72.7 & 1.9 & -0.8 \\
\hline Italy & 50.1 & 49.9 & 47.2 & 52.8 & 44.7 & 55.3 & -2.9 & -2.5 \\
\hline Luxembourg & 78.5 & 21.5 & 70.0 & 30.0 & 76.1 & 23.9 & -8.5 & 6.1 \\
\hline Latvia & 46.7 & 53.3 & 44.5 & 55.5 & 41.1 & 58.9 & -2.2 & -3.4 \\
\hline Malta & 51.3 & 48.7 & 57.3 & 42.7 & 56.4 & 43.6 & 6.0 & -0.9 \\
\hline Netherlands & 39.2 & 60.8 & 39.3 & 60.7 & 33.6 & 66.4 & 0.1 & -5.6 \\
\hline Portugal & 67.4 & 32.6 & 69.7 & 30.3 & 65.8 & 34.2 & 2.3 & -4.0 \\
\hline Slovenia & 64.0 & 36.0 & 62.8 & 37.2 & 53.6 & 46.4 & -1.2 & -9.2 \\
\hline Slovakia & 46.0 & 54.0 & 41.9 & 58.1 & 41.6 & 58.4 & -4.1 & -0.3 \\
\hline
\end{tabular}

Sources: Eurostat and authors' calculations. 
Current account dynamics witnessed heterogeneous developments across euro area member states since the inception of the euro. Prior to the 2007-2008 financial crisis, growing imbalances of deficit countries were to a large extent driven by deteriorating intra-euro area goods trade, reflecting considerable price competitiveness losses vis-à-vis other euro area trading partners (see Table 3$)^{6}$. Surplus countries largely saw improvements in their current account balances mainly on account of gains in trade with countries outside the monetary union. The pre-crisis pattern of growing imbalances in the deficit countries was reversed on the back of positive developments in both extra- and intra- euro area trade, with the extra-euro area trade correction contributing more in the cases of Cyprus, Estonia, Ireland, Latvia and Slovakia ${ }^{7}$. The unwinding of external imbalances in the deficit countries was triggered by the collapse in domestic demand (largely visible in the declining path of intra-euro area imports ratio to GDP; see Table A3 in Appendix) and subsequently by improving export performance (evident mainly by the growing ratio of extra-euro area exports; see Table A2 in Appendix). The above described patterns hold if balances net of energy are analysed (see Table A4 in Appendix).

Table 3

Current account balances (CA) and intra- versus extra-euro area goods trade balances (percent of GDP)

\begin{tabular}{|c|c|c|c|c|c|c|c|c|c|c|c|c|c|c|c|}
\hline \multirow[t]{2}{*}{ Country } & \multicolumn{3}{|c|}{2000} & \multicolumn{3}{|c|}{2007} & \multicolumn{3}{|c|}{2013} & \multicolumn{3}{|c|}{2007 vs 2000} & \multicolumn{3}{|c|}{2013 vs 2007} \\
\hline & \begin{tabular}{|r|}
$\mathrm{CA}$ \\
balance
\end{tabular} & \begin{tabular}{|r|} 
intra- \\
euro \\
area \\
trade \\
balance \\
\end{tabular} & \begin{tabular}{|r|} 
extra- \\
euro \\
area \\
trade \\
balance \\
\end{tabular} & $\begin{array}{r}\mathrm{CA} \\
\text { balance }\end{array}$ & \begin{tabular}{|r|} 
intra- \\
euro \\
area \\
trade \\
balance \\
\end{tabular} & \begin{tabular}{|r|} 
extra- \\
euro \\
area \\
trade \\
balance \\
\end{tabular} & $\begin{array}{r}\mathrm{CA} \\
\text { balance }\end{array}$ & $\begin{array}{r}\text { intra- } \\
\text { euro } \\
\text { area } \\
\text { trade } \\
\text { balance }\end{array}$ & \begin{tabular}{|r|} 
extra- \\
euro \\
area \\
trade \\
balance \\
\end{tabular} & $\begin{array}{r}\mathrm{CA} \\
\text { balance }\end{array}$ & \begin{tabular}{|r|} 
intra- \\
euro \\
area \\
trade \\
balance \\
\end{tabular} & \begin{tabular}{|r|} 
extra- \\
euro \\
area \\
trade \\
balance \\
\end{tabular} & $\begin{array}{r}\mathrm{CA} \\
\text { balance }\end{array}$ & \begin{tabular}{|r|} 
intra- \\
euro \\
area \\
trade \\
balance \\
\end{tabular} & $\begin{array}{r}\text { extra- } \\
\text { euro } \\
\text { area } \\
\text { trade } \\
\text { balance }\end{array}$ \\
\hline Austria & -0.73 & -4.72 & 2.33 & 3.51 & -5.67 & 5.93 & 2.70 & -5.44 & 3.66 & 4.2 & -1.0 & 3.6 & -0.8 & 0.2 & -2.3 \\
\hline Belgium & 4.03 & 6.73 & -2.08 & 1.89 & 5.71 & -1.49 & -1.56 & 2.92 & 0.78 & -2.1 & -1.0 & 0.6 & -3.5 & -2.8 & 2.3 \\
\hline Cyprus & -5.38 & -13.60 & -15.78 & -11.73 & -18.52 & -14.47 & -1.88 & -13.68 & -6.02 & -6.4 & -4.9 & 1.3 & 9.9 & 4.8 & 8.5 \\
\hline Germany & -1.73 & 1.33 & 1.63 & 7.45 & 2.92 & 5.18 & 7.52 & 0.13 & 7.31 & 9.2 & 1.6 & 3.5 & 0.1 & -2.8 & 2.1 \\
\hline Estonia & -5.37 & -8.91 & -9.46 & -15.95 & -13.79 & -7.04 & -1.00 & -7.34 & 0.08 & -10.6 & -4.9 & 2.4 & 14.9 & 6.5 & 7.1 \\
\hline Spain & -3.96 & -3.16 & -3.84 & -10.00 & -4.19 & -5.24 & 0.78 & 0.46 & -1.88 & -6.0 & -1.0 & -1.4 & 10.8 & 4.7 & 3.4 \\
\hline Finland & 7.78 & 3.43 & 6.16 & 4.26 & -0.69 & 4.44 & -1.07 & -2.37 & 1.53 & -3.5 & -4.1 & -1.7 & -5.3 & -1.7 & -2.9 \\
\hline France & 1.23 & -1.62 & 0.81 & -1.00 & -3.11 & 0.40 & -1.35 & -4.20 & 0.55 & -2.2 & -1.5 & -0.4 & -0.3 & -1.1 & 0.1 \\
\hline Greece & -7.70 & -9.69 & -7.44 & -14.61 & -9.23 & -9.07 & 0.75 & -4.62 & -6.13 & -6.9 & 0.5 & -1.6 & 15.4 & 4.6 & 2.9 \\
\hline Ireland & -0.36 & 18.39 & 8.39 & -5.34 & 10.14 & 4.26 & 6.61 & 11.05 & 11.28 & -5.0 & -8.2 & -4.1 & 12.0 & 0.9 & 7.0 \\
\hline Italy & -0.20 & -0.28 & 0.48 & -1.28 & -0.51 & -0.09 & 1.01 & -0.34 & 2.27 & -1.1 & -0.2 & -0.6 & 2.3 & 0.2 & 2.4 \\
\hline Luxembourg & 13.22 & -13.34 & -1.48 & 10.09 & -6.64 & -3.41 & 5.19 & -10.18 & -2.05 & -3.1 & 6.7 & -1.9 & -4.9 & -3.5 & 1.4 \\
\hline Latvia & -4.89 & -10.36 & -6.76 & -22.40 & -13.66 & -11.09 & -0.82 & -9.24 & -1.31 & -17.5 & -3.3 & -4.3 & 21.6 & 4.4 & 9.8 \\
\hline Malta & -12.18 & -27.95 & 3.95 & -6.15 & -21.34 & 3.69 & 1.42 & -22.21 & -2.27 & 6.0 & 6.6 & -0.3 & 7.6 & -0.9 & -6.0 \\
\hline Netherlands & 2.04 & 16.75 & -12.98 & 6.72 & 18.23 & -10.92 & 10.38 & 24.44 & -15.38 & 4.7 & 1.5 & 2.1 & 3.7 & 6.2 & -4.5 \\
\hline Portugal & -10.34 & -9.18 & -4.21 & -10.10 & -9.59 & -3.28 & 0.51 & -5.22 & -0.33 & 0.2 & -0.4 & 0.9 & 10.6 & 4.4 & 2.9 \\
\hline Slovenia & -2.69 & -5.78 & -1.20 & -4.17 & -8.78 & 5.68 & 6.30 & -0.18 & 1.63 & -1.5 & -3.0 & 6.9 & 10.5 & 8.6 & -4.0 \\
\hline Slovakia & -3.41 & 4.46 & -8.72 & -5.31 & 6.08 & -8.55 & 2.14 & 4.43 & 0.43 & -1.9 & 1.6 & 0.2 & 7.5 & -1.6 & 9.0 \\
\hline
\end{tabular}

Sources: Eurostat and authors' calculations.

\footnotetext{
${ }^{6}$ Deficit countries include countries that registered a current account deficit in the year 2007: Cyprus, Estonia, Spain, France, Greece, Ireland, Italy, Latvia, Malta, Portugal, Slovenia and Slovakia. Surplus countries include countries that registered a current account surplus in 2007: Austria, Belgium, Germany, Finland, Luxembourg and the Netherlands.

${ }^{7}$ Owing to the positive contribution of extra-euro area trade in recent correction of current account deficits, the unweighted average of extra-euro area current account balance as a percent of GDP stood close to zero at the end of 2013.
} 
The remaining part of this section sheds some light on the developments and the role of price competitiveness in the external adjustment in the euro area. Overall, various price and cost competitiveness measures, i.e. various harmonised competitiveness indicators $(\mathrm{HCIs})^{8}$, point to similar developments in price/cost competitiveness, apart from the HCI based on unit labour costs in manufacturing (ULCM), which conveys a somewhat different message in a number of cases. In Cyprus, Greece, Ireland, Italy, Luxembourg and Malta, the ULCM-based HCIs deviated considerably from other indicators in the first decade of the 2000s; also, Germany and Finland recorded some temporary deviations. ${ }^{9}$

\section{Chart 1}

\section{Decomposition of CPI-based HCIs}

(percentage change Q1 2000-Q4 2007;

contributions in percentage points)

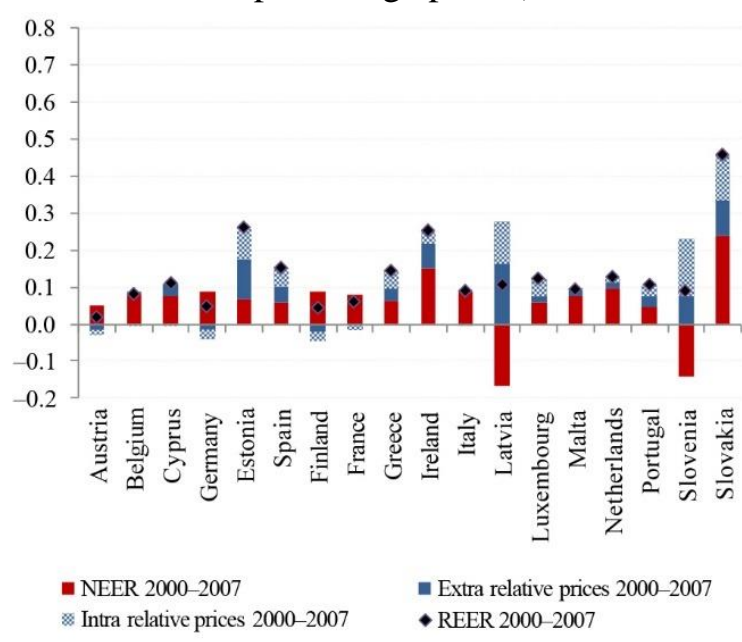

Sources: ECB and authors' calculations.

\section{Chart 2}

\section{Decomposition of ULCM-based HCIs} (percentage change Q1 2000-Q4 2007; contributions in percentage points)

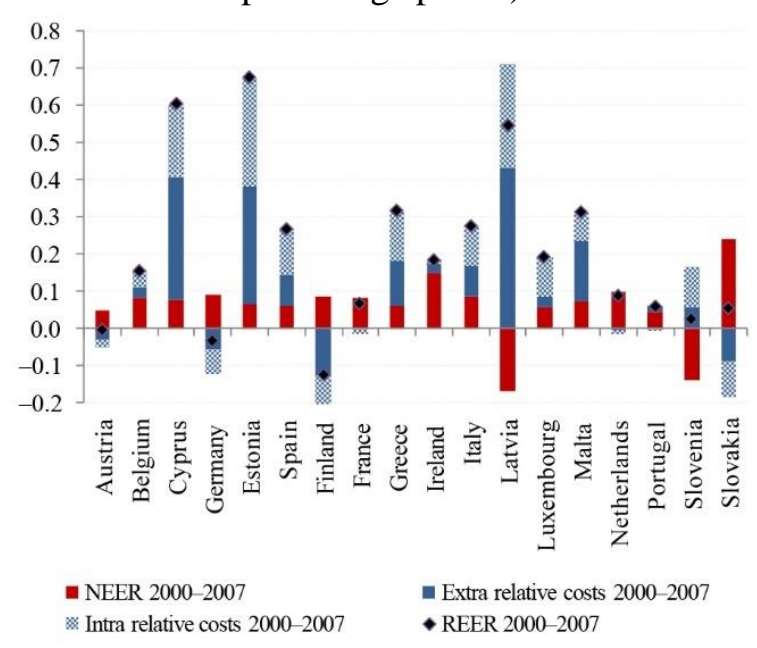

Sources: ECB and authors' calculations.

Charts 1 and 2 present the decomposition of the change in the CPI-based and ULCMbased HCIs into separate contributions from changes in the nominal effective exchange rate (NEER) and relative prices/costs with respect to trading partners within and outside the euro area. Based on these two different HCIs, in the period before the crisis, almost all euro area countries (except Germany, Austria and Finland) were faced with large losses in their price competitiveness. These losses are to a large extent attributable to nominal appreciation of the euro, as well as in the case of the deficit countries to stronger increases in their relative costs and prices as compared to trading partners both within and outside the monetary union. The same patterns can be broadly observed when the rest of the HCIs are employed, and the relevant results are presented in Charts A1 to A3 in Appendix. In the deficit economies, a larger real appreciation was recorded in terms of labour costs-based HCIs, in particular when the ULCM were considered. This reflected rising wages in excess of productivity, as

\footnotetext{
${ }^{8}$ For a thorough discussion on the merits and shortcomings of different HCIs, see Ca' Zorzi and Schnatz (2007), and Schmitz et al. (2012).

${ }^{9}$ Several institutions raised concerns regarding the appropriateness of using the ULCM-based HCIs to gauge a country's external competitiveness. Deutsche Bundesbank (1998) considers that a possible source of ULCMbased HCI deviation from other indicators is the different degree of change towards capital intensive production across trading partners. For the case of Italy, Giordano and Zollino (2015) suggest that the divergent path of the ULCM-based HCIs is attributable to the different degrees of production offshoring and outsourcing across trading partners.
} 
capital inflows prior to the crisis were channelled largely into the non-tradable sector, fuelling domestic demand growth.

On the other hand, Germany, Austria and Finland were faced with declines in relative intra- and extra-euro area labour costs, which were strong enough to counteract the nominal exchange rate appreciation of the euro and led to decline in the ULCM-based HCIs. Germany experienced price competitiveness gains within the euro area by managing its production costs. Productivity grew faster than wages in the pre-crisis period, in contrast to the trend observed in most of the deficit countries, keeping ULC contained. Moreover, comprehensive labour market reforms that led to wage moderation and the outsourcing of some parts of the production chain to low cost trading partners also contributed to lower production costs.

In the wake of the crisis, price competitiveness improvements across the euro area countries have largely been driven by reducing relative costs vis-à-vis non-euro area countries, while the contribution of cost cutbacks relative to euro-area trading partners was smaller (see Charts 3 and 4). The nominal depreciation of the euro has also contributed to lowering relative costs.

\section{Chart 3}

\section{Decomposition of CPI-based HCIs}

(percentage change Q1 2008-Q4 2013; contributions in percentage points)

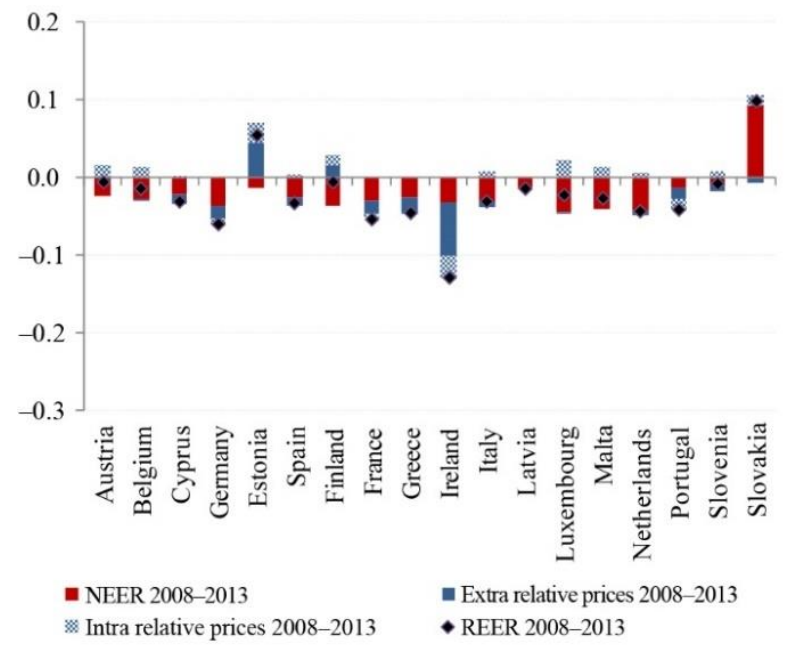

Sources: ECB and authors' calculations.

\section{Chart 4}

\section{Decomposition of ULCM-based HCIs} (percentage change Q1 2008-Q4 2013; contributions in percentage points)

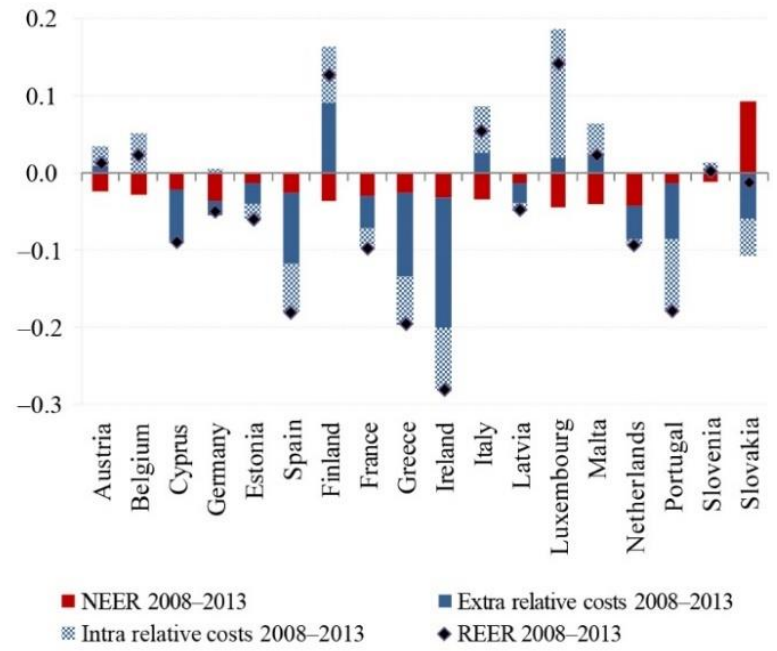

Sources: ECB and authors' calculations.

Deficit economies witnessed significant gains in price and cost competitiveness, in particular when measured by unit labour costs in total economy (ULCT) and ULCMbased HCIs. This is attributable to labour shedding and wage cuts and, where implemented, a shift from labour taxation to consumption taxation (in countries such as Slovenia, Portugal, Greece, Ireland and Spain, with the latter two countries decreasing social security contributions) ${ }^{10}$. This shift in the taxation burden from

\footnotetext{
${ }^{10}$ Bernardi (2013) reports that for the period 2010-2014, a real total tax shift, i.e. a change in the composition of the revenue side of the budget, consisting of increases in indirect taxes together with reductions in direct taxes and/or social security contributions, can be observed in such eight countries as Luxembourg, Finland, Slovenia, Germany, Portugal, Austria, Greece and Italy as a consequence of the increase in indirect taxes,
} 
labour to consumption also explains why price competitiveness improvements, measured by price indices rather than labour cost indices, have so far been limited.

The nature and the speed of adjustment have been different across deficit countries. In some cases, labour cost correction has occurred mainly via productivity gains through labour shedding (that was particularly evident in Spain and Portugal). In a set of countries, it resulted largely from a fall in compensation per employee (Greece and, at the onset of the crisis, Latvia). A more balanced composition of factors driving ULC improvement has thus far been observed in Ireland ${ }^{11}$. All in all, an increase in productivity coupled with a fall in wages has pushed labour costs sharply below the pre-crisis levels.

By contrast, some of the surplus countries (in particular Austria, Belgium, Luxembourg and Finland) as well as Italy witnessed increasing ULCM-based HCIs especially with respect to their intra-euro area trading partners. The surplus countries witnessed positive growth in their total ULC in the post crisis period, driven mainly by robust annual compensation per employee growth of around $2 \%$ on average. The case of Italy has already been thoroughly examined by Giordano and Zollino (2015) pointing at stagnating productivity coupled with increasing labour costs, as Italy was less able to take advantage from rising global value chains and labour outsourcing in comparison to other big industrialised EU economies, such as Germany.

In a nutshell, these stylised facts point to a shift in trade patterns towards extraeuro area trade in the aftermath of the international financial crisis. Prior to the crisis, the deficit economies witnessed large current account deficits due to the loss of price competitiveness vis-à-vis their intra- and extra-euro area trading partners, as domestic costs rose faster than productivity in relative terms. The rebalancing was feasible via a collapse in imports and a surge in extra-euro area exports, facilitated by, among other avenues, a moderation in compensation per employee and a rise in productivity ${ }^{12}$. On the other hand, prior to the crisis, surplus countries gained competitiveness by keeping labour costs moderate, both with respect to extra- and intra-euro area trading partners, as productivity grew stronger than wages. However, in the wake of the crisis, surplus countries lost part of their competitive advantage, as wages increased at a constant pace, especially vis-à-vis their intra-euro area partners, with the role of productivity being smaller.

coupled with a reduction in social security contributions (or direct taxes in the cases of Luxembourg and Italy). On the other hand, a partial tax shift, i.e. an increase (reduction) in total taxes, achieved by means of an increase (reduction) in indirect taxes (direct taxes and/or social security contributions), was reported in Estonia (direct taxes and social security contributions), France and Malta (indirect taxes), and Spain (social security contributions). Social security contributions as share of GDP fell in Finland, Slovenia, Ireland, Germany, Estonia, Portugal, Austria, Greece, Italy and Spain.

${ }^{11}$ For a more detailed discussion of factors driving a fall in ULC refer to Kang and Shambaugh (2015).

${ }^{12}$ Recent studies also emphasised the role of declining domestic demand for export growth via the search of new markets (see Esteves and Rua (2013), and Bobeica et al. (2016)). 


\section{DATA AND METHODOLOGY DESCRIPTION}

In this study, we explore the impact of cost/price competitiveness on exports and imports of 18 individual euro area member states (excluding Lithuania). We employ a standard econometric framework where exports (imports) of goods are explained by their traditional determinants, i.e. foreign demand (domestic demand) and relative price indices, also investigating short and long run dynamics. Regarding imports, we also account for the import content of exports by including exports in import equations. All the variables are on a quarterly basis, seasonally adjusted and expressed in logarithms. The time period used in the estimations is first quarter of 1995 to third quarter of $2013^{13}$.

Real exports (imports) are expressed as volume indices of goods only, since the intra/extra euro area breakdown of exports (imports) of services is not available ${ }^{14}$. Export and import data are collected from Eurostat External Trade Statistics. The HCIs are based on relative measures of CPI, domestic sales producer price index (PPI), ULCM, ULCT and GDP deflators against the other 17 countries of the euro area in the case of intra-euro area trade and against the 19 most important trading partners of the euro area ${ }^{15}$ in the case of extra-euro area trade. The foreign demand index is computed as a geometric weighted average of import volumes of the trading partners (see Hubrich and Karlsson (2010)). The data needed for calculations of import-adjusted domestic demand and import volumes excluding energy are taken from Eurostat ${ }^{16}$.

We follow the two-step Engle and Granger procedure, whereby in the first stage we estimate the long-run cointegration relationships after having tested for the presence of unit roots ${ }^{17}$, and in the second stage we estimate short-run dynamic equations in the form of error correction models (ECMs), with deviation from the long-run equilibrium being fed into the ECM.

In the case of exports, the following long-run specification was employed:

$\log X_{t}=\alpha_{0}+\alpha_{1} \log F D_{t}+\alpha_{2} \log H C I_{t}+u_{t}$

where $\log X_{t}$ is the logarithm of export volume of goods at time $t, \log F D_{t}$ stands for the logarithm of index of foreign demand at time $t$, and $\operatorname{logHCI}_{t}$ denotes the logarithm of one of the relative price and cost competitiveness measures mentioned above, whereby an increase denotes an appreciation; $u_{t}$ is a temporary deviation of exports

\footnotetext{
${ }^{13}$ For Austria and Finland, the sample period starts in the first quarter of 1996, for Luxembourg in the first quarter of 1999, for Cyprus, Malta, Slovenia, Slovakia and Estonia in the first quarter of 2000.

${ }^{14}$ Furthermore, the use of trade in services would most likely result in a poor fit, as previously documented, albeit on the aggregate level, by Christodoulopoulou and Tkačevs (2016), and Giordano and Zollino (2015), suggesting that services trade determinants may appear broader as compared to goods trade.

15 Australia, Canada, China, Denmark, Hong Kong, Japan, Norway, Singapore, South Korea, Sweden, Switzerland, the Czech Republic, the United Kingdom, the United States, Hungary, Lithuania, Poland, Bulgaria and Romania. In this study, Lithuania is still treated as one of the most important trading partner countries outside the euro area (see also the first sentence of Section 4).

${ }^{16}$ Real imports excluding energy were computed by dividing total imports at current prices by the respective unit value index. We divided imports of the SITC Rev. 3 Section 3 proxying for energy with the respective unit value index. This yields total imports and energy imports at constant prices. As a final step, we subtracted energy imports at constant prices from total imports at constant prices to get imports excluding energy.

${ }^{17}$ We perform two distinct unit root tests: the augmented Dickey-Fuller (ADF) test and the KwiatkowskiPhillips-Schmidt-Shin (KPSS) test for the set of variables used both in levels and in first differences. The results are largely consistent across the tests, pointing to the presence of a unit root in all variables, suggesting that they can be further treated as I (1). Results are available upon request.
} 
from their long-term cointegration relationship. $\alpha_{1}$ is expected to be positive and close to 1 , since a country is expected to have a stable export market share in the long term. As worsening of price competitiveness is likely to be negatively associated with exports, $\alpha_{2}$ is expected to be negative.

The specification of the short-run export equation is the following:

$\Delta \log X_{t}=\beta_{0}+\beta_{1 i} \sum_{i=1}^{p} \Delta \log X_{t-i}+\beta_{2 i} \sum_{i=0}^{q} \Delta \log F D_{t-i}+$

$\beta_{3 i} \sum_{i=0}^{\mu} \Delta \log H C I_{t-i}+\gamma u_{t-1}+\varepsilon_{t}$

where $\gamma$ is related to the speed of export adjustment towards the long-run equilibrium, and $\beta_{s}$ are the short-term coefficients to be estimated. $\Delta$ denotes first differences of variables.

Similarly, the following long-run equation has been estimated for imports:

$\log M_{t}=\theta_{0}+\theta_{1} \log D D_{t}+\theta_{2} \log H C I_{t}+\theta_{3} \log X_{t}+\omega_{t}$

where $\log M_{t}$ represents the logarithm of import volume of goods at time $t$, $\log D D_{t}$ denotes the logarithm of domestic demand at time $t, \log H C I_{t}$ stands for one of the relative price and cost competitiveness measures, $\log X_{t}$ denotes the logarithm of export volume of goods and services, while $\omega_{t}$ is a temporary deviation of imports from their long-term cointegration relationship. All of the elasticities are expected to be positive.

The short-run equation for imports is the following:

$\Delta \log M_{t}=\delta_{0}+\delta_{1 i} \sum_{i=1}^{p} \Delta \log M_{t-i}+\delta_{2 i} \sum_{i=0}^{q} \Delta \log D D_{t-i}+$

$\delta_{3 i} \sum_{i=0}^{\mu} \Delta \log H C I_{t-i}+\delta_{4 i} \sum_{i=0}^{\epsilon} \Delta \log X_{t-i}+\varphi \omega_{t-1}+\varepsilon_{t}$

where $\varphi$ denotes the speed of adjustment of imports of goods towards their long-run equilibrium, and $\delta_{\mathrm{s}}$ are short-term coefficients.

We make use of two types of cointegration tests (the Engle-Granger and the PhillipsOuliaris tests) to verify cointegration in 3 possible specifications of the long-run equation (a specification without a trend, with a linear trend, and with both a linear trend and a quadratic trend). Dummies are added, if needed, for the treatment of outliers. We retain the most parsimonious model for which cointegration is identified. As subsequently discussed, it was not always possible to identify a cointegration relationship. In those cases, we present evidence assuming only a short-run relationship. For the short-run equations, we follow the "general-to-specific approach" by starting with 4 lags and automatically removing the insignificant ones. We also check for residuals to be normally distributed and serially uncorrelated. We have eliminated all coefficients, which were theoretically implausible and might have resulted from the crisis generating some erratic shifts in the relationship between exports/imports and their determinants. In many instances, the residuals during the crisis period are very large, showing that trade volumes have fallen more than implied by demand and relative prices within this simple econometric framework. 


\section{EMPIRICAL FINDINGS}

The estimation results are presented in Tables A5-A24. In addition to coefficients and their significance levels we report the adjusted R2, the Breusch-Godfrey LM test for autocorrelation up to the fourth order, and the Jarque-Bera normality test for error correction equations, as well as the Wald test for the null hypothesis that foreign demand (domestic demand) elasticity is equal to one in the long-run equation of exports (imports). Test results confirm that residuals are normally distributed and are not serially correlated in most of the ECMs.

\section{Export equations}

The estimation results suggest that export volumes outside the euro area appear to be driven to a larger extent by price/cost competitiveness than those within the common currency area (see also Table 4 for the summary of HCI elasticities).

Table 4 Elasticity of exports with respect to HCIs in estimated long-term equations

\begin{tabular}{|c|c|c|c|c|c|c|c|c|c|c|c|c|c|c|c|c|c|c|c|}
\hline & HCI based on: & $\mathrm{AT}$ & $\mathrm{BE}$ & $\mathrm{CY}$ & DE & EE & ES & FI & $\mathrm{FR}$ & GR & IE & IT & $\mathrm{LU}$ & $\mathrm{LV}$ & MT & $\mathrm{NL}$ & PT & SI & SK \\
\hline \multirow{5}{*}{$\begin{array}{l}\text { Intra- } \\
\text { area } \\
\text { exports }\end{array}$} & CPI & $\mathrm{x}$ & $\begin{array}{ll}-1.322^{* * *} \\
\end{array}$ & $\mathrm{x}$ & $\mathrm{x}$ & $\mathrm{x}$ & $\mathrm{x}$ & $\mathrm{x}$ & $\mathrm{x}$ & $\mathrm{x}$ & $\mathrm{x}$ & $\mathrm{x}$ & $\mathrm{x}$ & $x$ & $x$ & \begin{tabular}{|l|l|}
$-1.347 * * *$ \\
\end{tabular} & $x$ & $x$ & $\mathrm{x}$ \\
\hline & GDP deflator & $\mathrm{x}$ & $-1.673^{* * *}$ & $\mathrm{x}$ & $\mathrm{x}$ & $\mathrm{x}$ & $\mathrm{x}$ & $\mathrm{x}$ & $x$ & $-1.038 * * *$ & $\mathrm{x}$ & $\mathrm{x}$ & $\mathrm{x}$ & $\mathrm{x}$ & $\mathrm{x}$ & \begin{tabular}{|l|}
$-1.534 * * *$ \\
\end{tabular} & $\mathrm{x}$ & $\mathrm{x}$ & \\
\hline & PPI & $\mathrm{x}$ & $\mathrm{x}$ & $\mathrm{x}$ & $\mathrm{x}$ & $\mathrm{x}$ & $\mathrm{x}$ & $\mathrm{x}$ & $\mathrm{x}$ & $\mathrm{x}$ & $\mathrm{x}$ & $\mathrm{x}$ & $\mathrm{x}$ & $\mathrm{x}$ & $\mathrm{x}$ & $-0.917 * *$ & $\mathrm{x}$ & $\mathrm{x}$ & \\
\hline & ULCM & $\mathrm{x}$ & $\mathrm{x}$ & $\mathrm{x}$ & $\mathrm{x}$ & $-0.629^{* * * *}$ & $-0.799 * * *$ & $\mathrm{x}$ & $\mathrm{x}$ & $\mathrm{x}$ & $-0.830^{\text {***** }}$ & $\mathrm{x}$ & $\mathrm{x}$ & $\mathrm{x}$ & $\mathrm{x}$ & $|-0.937 * * * *|$ & $\mathrm{x}$ & $\mathrm{x}$ & \\
\hline & ULCT & $\mathrm{x}$ & $x$ & $\mathrm{x}$ & 1 & $-0.974 * * *$ & $-1.134^{* * * *}$ & $x$ & $\mathrm{x}$ & $-0.421^{* *}$ & $-1.387 * * *$ & $|-0.869 * *|$ & $\mathrm{x}$ & 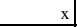 & $x$ & $|-1.501 * * *|$ & $x$ & $x$ & \\
\hline \multirow{5}{*}{\begin{tabular}{|l} 
Extra- \\
area \\
exports
\end{tabular}} & CPI & $-0.610^{* * * *}$ & $-0.391 * * *$ & $-0.904 * *$ & $-0.281 * * *$ & $-1.966^{6 * * *}$ & $-0.440^{* * * * *}$ & $-0.240 *$ & $-0.670^{* * * *}$ & $-0.630^{* * * *}$ & $-1.032 * * *$ & $-0.494^{* * * *}$ & $\mathrm{x}$ & $-0.489^{* * * *}$ & $\mathrm{x}$ & $|-0.166 * * *|$ & $-0.147 *$ & $-0.418^{* * * *}$ & \\
\hline & \begin{tabular}{|l|} 
GDP deflator \\
\end{tabular} & -0.614 **** & $-0.384 * * *$ & $-0.760 * *$ & \begin{tabular}{l|l|}
$-0.285 * * *$ \\
\end{tabular} & $-1.084 * *$ & -0.407 **** & \begin{tabular}{|c|}
$-0.290 * *$ \\
\end{tabular} & $-0.700^{* * * *}$ & $-0.626 * * *$ & $-1.146^{* * * *}$ & $\mid-0.489 * * *$ & $\mathrm{x}$ & $-0.403^{* * * *}$ & $\mathrm{x}$ & $|-0.176 * * *|$ & $-0.165^{\text {*** }}$ & $-0.394^{* * *}$ & \\
\hline & PPI & -0.711 **** & $-0.479 * * *$ & $-0.731 * *$ & $-0.288 * * * *$ & $-1.808 * * *$ & $-0.505^{* * * *}$ & $-0.430^{* * * *}$ & $-0.750 * * *$ & $-0.764 * * *$ & $-1.448^{* * * *}$ & $-0.578^{* * * *}$ & $x$ & $-0.460^{* * * *}$ & $x$ & $\mid-0.218^{* * * *}$ & $-0.176^{*}$ & $-0.364 * *$ & \\
\hline & ULCM & $-0.452^{* * * *}$ & $-0.355^{* * * *}$ & $-0.525 * *$ & $-0.270 * * *$ & $-0.411 *$ & $-0.354 * * * *$ & $-0.248 * *$ & $-0.600^{* * * *}$ & $\begin{array}{l}-0.492 * * * \\
\end{array}$ & $-0.553^{* * * *}$ & $\mid-0.391$ **** & $\mathrm{x}$ & -0.179 **** & $\mathrm{x}$ & $\mid-0.129 * * *$ & -0.157 ** & $-0.223 *$ & \\
\hline & ULCT & $-0.578 * * *$ & $-0.388^{* * * *}$ & $-0.636 * *$ & $-0.291 * * *$ & $-0.650^{* * * *}$ & $-0.412 * * *$ & -0.270 *** & $-0.647 * * *$ & $-0.443 * * *$ & $-0.747^{* * * *}$ & $-0.408 * * *$ & $\mathrm{x}$ & $-0.208 * * *$ & & $|-0.157 * * *|$ & $-0.141 *$ & $-0.325 * *$ & \\
\hline
\end{tabular}

Notes: $* * *, * *$ and $*$ imply significance levels at $1 \%, 5 \%$ and $10 \%$ respectively. $\mathrm{x}$ denotes the absence of value.

This is supported by the fact that the long-run relationship between exports and price competitiveness appears to be statistically significant in more cases of extra-euro area exports as compared to intra-euro area exports. In particular, extra-euro area exports of most countries are found to be cointegrated with relative prices across all HCIs. In the case of intra-euro area exports, we were able to identify a cointegration relationship for a smaller number of countries (Belgium, Ireland, Estonia, Spain, the Netherlands, Greece and Italy). This may be related to some profound structural changes, especially in the new euro area member states, such as the integration in the EU. Furthermore, the global financial crisis that brought about a large drop in trade volumes might have left its mark on the standard relationship between intra-euro area exports and relative prices. Where cointegration was identified, there are generally more instances with HCIs being significant in the long-term relationships as compared to short-run equations (Tables A5-A14 in Appendix), implying that relative prices are less important in the short run, as agents need time to adjust their consumption patterns to changing prices. This finding is in line with previous studies (e.g. Stirböck (2006)). Most long-term elasticity coefficients of HCIs in export equations lie, as indicated by economic theory, between 0 and -1 . There are, however, some exceptions, as is the case of Estonian extra-euro area exports, for which the HCIs based on CPI and PPI are larger than 1 in absolute value. This can be due to the limited available sample and radical changes this economy had undergone; the inclusion of dummies, which remove outliers, strongly influences the magnitude of the coefficients.

Foreign demand appears to be a robust driver of export volumes across countries and HCIs. The long-run impact of foreign demand on both intra- and extra-euro area exports is in most instances not significantly different from unity. Still, in some countries, demand elasticity was found to be different from 1 , which means gaining 
or losing an export market share. This finding is robust to different specifications of intra-euro area export equations for Belgium, Finland, the Netherlands, Slovenia and to some extent Estonia. For extra-euro area exports, this finding is evident in the case of Cyprus, France, Estonia, Greece, Slovenia, Slovakia and Latvia. It appears that foreign demand elasticity tends to be below 1 in old EU Member States, whereas some new EU Member States (and also Finland) have clearly gained from increased trade integration within the EU as well as from improving technologies and qualities of their products. Foreign demand appears to be an important driver of exports also in the short run, mostly contemporaneously with a coefficient generally around 1 .

In order to investigate whether the global financial crisis has impacted the standard relationship between exports and relative prices, we have also run exports regressions over a shorter sample ending prior to the euro area recession due to the global financial crisis (up to the first quarter of 2008). In the case of intra-euro area exports the number of specifications where HCI appears significant, with a theoretically correct sign and of reasonable magnitude is larger as compared to the full sample (see Table 5). Not surprisingly, the standard relationship seems to have broken down during the crisis mainly in countries that were particularly hit by it, i.e. Estonia, Spain, Ireland, Latvia, Portugal and Slovenia. Moreover, for Portugal, Latvia and Slovenia none of different HCIs employed in the study appears significant or correctly signed in the full sample. In the case of extra-euro area countries, the number of cases where HCIs are significant before and after the crisis is similar.

Table 5

Elasticity of exports with respect to HCIs in long-term equations (sample up to Q1 2008)

\begin{tabular}{|c|c|c|c|c|c|c|c|c|c|c|c|c|c|c|c|c|c|c|c|}
\hline & HCI based on: & AT & $\mathrm{BE}$ & $\mathrm{CY}$ & $\mathrm{DE}$ & $\mathrm{EE}$ & ES & $\mathrm{FI}$ & $\mathrm{FR}$ & GR & $\mathrm{IE}$ & IT & $\mathrm{LU}$ & LV & MT & NL & PT & SI & SK \\
\hline \multirow{5}{*}{\begin{tabular}{|l|} 
Intra- \\
area \\
exports
\end{tabular}} & CPI & $\mathrm{x}$ & $\mathrm{x}$ & $\mathrm{x}$ & $\mathrm{x}$ & $\mathrm{x}$ & $-1.048^{*}$ & $\mathrm{x}$ & $\mathrm{x}$ & $\mathrm{x}$ & \begin{tabular}{|l|l|}
$-1.256 * * *$ \\
\end{tabular} & $\mathrm{x}$ & $\mathrm{x}$ & $-0.410 * * *$ & $\mathrm{x}$ & $-1.343 * * *$ & $\mathrm{x}$ & $\mid-1.404 * * *$ & \\
\hline & GDP deflator & $\mathrm{x}$ & $\mathrm{x}$ & $\mathrm{x}$ & $\mathrm{x}$ & $\mathrm{x}$ & $-1.108 * *$ & $\mathrm{x}$ & $\mathrm{x}$ & $\mid-0.920$ **** & $-0.904 * * *$ & $\mathrm{x}$ & $\mathrm{x}$ & $-0.327^{* * * *}$ & $\mathrm{x}$ & -1.170 **** & $-1.773^{* * *}$ & $-0.657 * * *$ & \\
\hline & PPI & $\mathrm{x}$ & $\mathrm{x}$ & $\mathrm{x}$ & $\mathrm{x}$ & -1.237 ** & $-1.324 * *$ & $\mathrm{x}$ & $\mathrm{x}$ & $\mathrm{x}$ & $-1.010^{* * *}$ & $\mathrm{x}$ & $\mathrm{x}$ & $-0.367 * * *$ & $\mathrm{x}$ & $-1.140^{* * * *}$ & $-0.305 * * *$ & $-0.310^{*}$ & $\mathrm{x}$ \\
\hline & ULCM & $\mathrm{x}$ & $\mathrm{x}$ & $\mathrm{x}$ & $\mathrm{x}$ & $-1.000 * *$ & $-1.134^{* * * *}$ & $-1.078 * * * *$ & -1.120 **** & $\mathrm{x}$ & $-0.464 * * *$ & $\mathrm{x}$ & $\mathrm{x}$ & $-0.212^{* * * *}$ & $\mathrm{x}$ & -0.776 **** & $\mathrm{A}^{2}$ & $\mathrm{x}$ & \\
\hline & ULCT & $\mathrm{x}$ & $\mathrm{x}$ & $\mathrm{x}$ & $\mathrm{x}$ & -0.918 ** & & 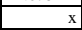 & $-1.520 * *$ & $\mathrm{x}$ & $-0.791 * * *$ & $\mathrm{x}$ & $\mathrm{x}$ & $-0.247 * * *$ & $\mathrm{x}$ & $-1.093^{* * *}$ & $-0.619^{*}$ & $x_{1}$ & \\
\hline \multirow{5}{*}{\begin{tabular}{|l|} 
Extra- \\
area \\
exports
\end{tabular}} & CPI & $197 *$ & $2222^{* *}$ & -1.907 **** & $-0.244 * * *$ & & $-0.211^{* * *}$ & \begin{tabular}{|l|}
$-0.371^{* * *}$ \\
\end{tabular} & 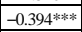 & \begin{tabular}{|l|}
$-0.783 * * * *$ \\
\end{tabular} & $\mid-1.116^{* * * *}$ & \begin{tabular}{|l|}
$-0.255 * * * *$ \\
\end{tabular} & $\mathrm{x}$ & $\mathrm{x}$ & $\mathrm{x}$ & $-0.333^{* * * *}$ & $\mathrm{x}$ & \begin{tabular}{|l|l|}
$-0.564 * * * *$ \\
\end{tabular} & \\
\hline & \begin{tabular}{|l} 
GDP deflator \\
\end{tabular} & $-0.207 *$ & $-0.225^{* *}$ & $\mid-2.064$ **** & $-0.243 * * *$ & $\mathrm{x}$ & $-0.215^{* * *}$ & \begin{tabular}{|l|l|}
$-0.448^{* * *}$ \\
\end{tabular} & -0.417 **** & $|-0.786 * * *|$ & $-1.175^{* * * *}$ & $-0.252^{* * * *} \mid$ & $\mathrm{x}$ & $\mathrm{x}$ & $\mathrm{x}$ & -0.365 **** & $\mathrm{x}$ & $|-0.571 * * *|$ & \\
\hline & PPI & $-0.221 *$ & $-0.281 * * *$ & $\mid-1.696 * * *$ & $-0.261 * * *$ & $\mathrm{x}$ & $-0.244^{* * *}$ & $-0.613^{* * * *}$ & $-0.466 * * *$ & $-0.932^{* * * *} \mid$ & $\mid-1.302 * * *$ & \begin{tabular}{|c|}
$-0.264 * * * *$ \\
\end{tabular} & $\mathrm{x}$ & $\mathrm{x}$ & $\mathrm{x}$ & $-0.416^{* * * *}$ & $\mathrm{x}$ & $-0.594 * * *$ & \\
\hline & ULCM & $-0.134 * *$ & $-0.198^{* *}$ & $-1.264^{* * *}$ & $\mid-0.248 * * * *$ & $\mathrm{x}$ & $-0.199^{* * *}$ & $-0.242^{*}$ & \begin{tabular}{|l|}
$-0.380^{* * * *}$ \\
\end{tabular} & $\mid$\begin{tabular}{|c|}
$-0.629 * * *$ \\
\end{tabular} & $\left|-0.830^{* * * *}\right|$ & $\left|-0.222^{* * * *}\right|$ & $\mathrm{x}$ & $x$ & $\mathrm{x}$ & $-0.283^{* * * *}$ & 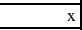 & $|-0.479 * * *|$ & \\
\hline & ULCT & $-0.165 *$ & $-0.202 *$ & -1.275 **** & $-0.236 * * * \mid$ & $\mathrm{x}$ & $-0.220^{* * *}$ & \begin{tabular}{|l|l|}
$-0.319 * *$ \\
\end{tabular} & $|-0.393 * * *|$ & $|-0.540 * * *|$ & $-1.059 * * *$ & $|-0.202 * * *|$ & $\mathrm{x}$ & $\mathrm{x}$ & & -0.310 **** & & $-0.518 * * *$ & \\
\hline
\end{tabular}

Notes: $* * *, * *$ and $*$ imply significance levels at $1 \%, 5 \%$ and $10 \%$ respectively. $\mathrm{x}$ denotes the absence of value.

Finally, we have also verified if the results still hold when considering the role of changes in the domestic demand in driving exports (see Esteves and Rua (2013) and Bobeica et al. (2016)). We found that exports are negatively related to lags of the domestic demand in the short run in the case of Latvia and Portugal (for flows within the monetary union) and in the case of Belgium, Germany, Estonia, Finland, Greece and Portugal (for flows outside the euro area) and also that HCIs short-run coefficients are not affected much and remain robust to the inclusion of domestic demand.

Overall, when judging by the number of significant HCIs in export equations, it appears that price/cost competitiveness is a relatively more important driver of extra-euro area exports as compared to intra-euro area ones. However, where significant, the magnitude of HCI elasticities is larger for intra-euro area exports, in line with most, though scarce, literature on intra- versus extra-euro area trade (see Table A1 in Appendix). The significance of HCIs in intra-euro area export equations for certain deficit countries, such as Greece, Ireland, Italy and Spain, indicates that wage moderation efforts in these economies are helpful in restoring competitiveness and external rebalancing within the euro area. That said, the global financial crisis seems to have distorted a standard relationship between exports and 
relative prices within the euro area, with price competitiveness being a less important driver of intra-euro area exports after the outbreak of the crisis. This phenomenon may be related to the growing importance of other factors, not accounted for in standard specifications of export equations: rising quality of exported goods (particularly in Latvia, Estonia and Greece ${ }^{18}$ ), temporary fall-back in integration of euro area countries into global value chains during the crisis (see Amador et al. (2015)), the role of falling domestic demand in stimulating exporting activities in some euro area countries, and the effect of recent indirect tax increases (implemented in many euro area countries as part of austerity programmes aimed at reducing budget deficits) on price competitiveness measures. It is not clear if and how the impact of these factors may have been different for intra-euro area exports as compared to extra-euro area exports, and this leaves space for future research.

\section{Import equations}

Import elasticity with respect to domestic demand is found to be statistically different from 1 in many more cases as compared to export demand elasticity. This finding is in line with other studies that estimated demand elasticity of imports to be higher than 1, probably owing to acceleration of FDI flows (see Barrell and te Velde (2002), and Barrell and Dées (2005)). Import demand elasticity tends to be larger in deficit countries, such as Cyprus, Spain, Greece, Italy and Slovenia, as capital inflows were channelled into non-tradable sectors, fuelling domestic and import demand. It is also high in the cases of Germany and Slovakia as well as Ireland, revealing their rapid integration into global value chains and the resulting demand for parts and components for final products. Related to this fact, exports have a generally positive and statistically significant effect, reflecting the increasing integration of the euro area countries in global value chains and the rising share of imports of intermediate goods. Import elasticities with respect to relative prices show large heterogeneity across countries (see Table 6). Most elasticities are between 0 and 1 , as suggested by the economic theory.

Table 6

\section{Elasticity of imports with respect to HCI}

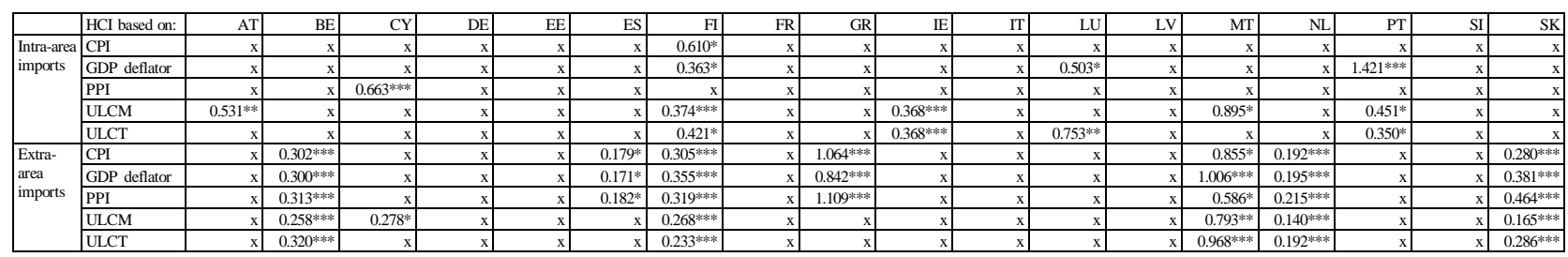

Notes: $* * *, * *$ and $*$ imply significance levels at $1 \%, 5 \%$ and $10 \%$ respectively. $\mathrm{x}$ denotes the absence of value.

Both intra- and extra-euro area imports of Germany, France, Estonia, Slovenia, Italy and Latvia appear insensitive to price competitiveness whichever HCI is employed. Weak responsiveness of imports to relative prices has already been identified by other studies, with the choice of HCI having no impact on the outcome. Of these studies, Christodoulopoulou and Tkačevs (2016) found an insignificant impact of HCIs on imports for Germany, France, Italy, Estonia and Slovenia for total trade flows.

\footnotetext{
${ }^{18}$ See Karadeloglou et al. (2015) for comparison between the developments in relative export prices adjusted for quality and taste and conventional relative prices.
} 
The number of cases where price competitiveness appears to significantly impact trade volumes is smaller for imports than exports. Global value chains and internationalisation of production processes, with the rise of multinational companies, can explain the sluggishness in adjustment of import volumes to price changes. Rising multinational companies apply special pricing strategies to their subsidiaries (which would not be affected by exchange rate fluctuations) given the constant supply flows among them. For Germany, another reason given as an explanation of the low responsiveness of extra-euro area imports to real effective exchange rate fluctuations is related to low price elasticity of high-quality intermediate goods imports (Stirböck (2006)).

A look at the short-run equations reveals the dominant role of domestic demand in driving imports. Interestingly, import elasticity to domestic demand for many countries is higher in the short run, which implies that there might be temporary overreaction of imports to cyclical expansions or contractions due possibly to lags in domestic production as time is needed to expand or contract local production whenever domestic demand grows or shrinks. The effect of exports remains positive and significant in most cases and is mainly contemporaneous. In the short run, price elasticity of imports is mostly found to be significant whenever a long run relationship between imports and relative prices is identified. For intra-euro area imports, broad economy-based price (GDP deflator) and cost (ULCT) competitiveness measures appear to have a significant impact in more instances than ULCM-based ones. In the case of extra-euro area imports, HCIs appear to be statistically significant more often than in the case of intra-euro area imports.

As in the case of exports, we analysed to what extent the crisis period had affected the relationship between imports and their traditional drivers by estimating import equations over a shorter pre-crisis sample, ending in the first quarter of 2008. The fact that extra-euro area imports are price sensitive in a larger number of countries than in the case of intra-euro area still holds (see Table 7). However, over the pre-crisis sample extra-euro area imports appear sensitive to relative price movements in more cases as compared to the full sample (with imports of Estonia, Germany, France, Italy and Latvia being sensitive to price competitiveness in the pre-crises period). This reduction in importance of price competitiveness in the wake of the crisis could be explained by several non-price competitiveness factors, the rising quality of exported goods in certain countries among them ${ }^{19}$, which would require high quality imported goods for their production, making imports less price elastic.

Table 7

Elasticity of imports with respect to HCIs in the long-term equations (sample up to Q1 2008)

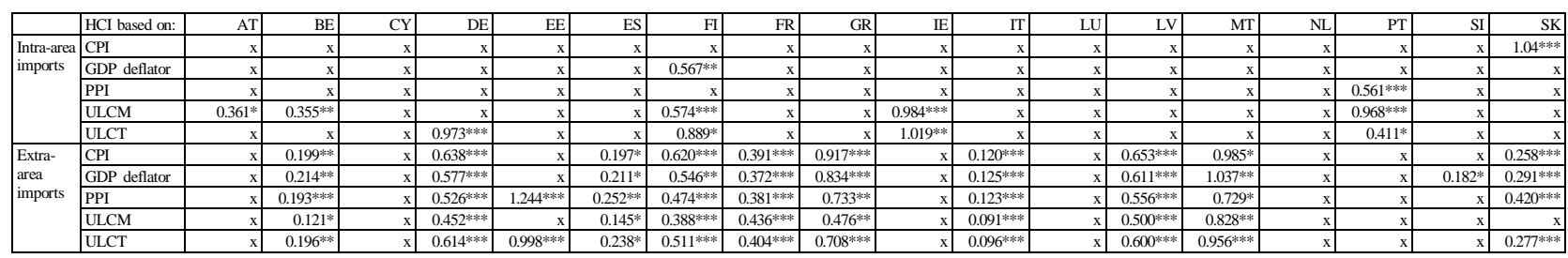

Notes: $* * * * *$ and $*$ imply significance levels at $1 \%, 5 \%$ and $10 \%$ respectively. $\mathrm{x}$ denotes the absence of value.

${ }^{19}$ See, for instance, Box 1 in the article entitled "Country adjustment in the euro area: where do we stand?", Monthly Bulletin, ECB, May 2013. 
To better capture the fact that the relationship between imports and exports has become stronger due to internationalisation of production and strong reliance of the production of traded goods on imported inputs, Bussière et al. (2013) use an alternative measure of domestic demand. This measure was found to perform better than traditional measures of domestic demand in explaining the great trade collapse during 2008-2009. We construct this alternative measure of both domestic demand and exports, accounting for the fact that different demand components are characterised by different import intensity levels, for example, investment is usually found to be more import intensive than, say, government consumption. Following Bussière et al. (2013) and Giordano and Zollino (2015), we use input-output tables providing us with import weights for each demand component (private and government consumption, investment and exports $)^{20}$. When this alternative measure of domestic demand is used, the results confirm comparatively minor role of relative prices in explaining imports over the full sample (see Table 8), while the role of exports is found to have increased as compared to baseline import equations for nearly all countries ${ }^{21}$.

Table 8

\section{Elasticity of imports with respect to HCIs using import adjusted demand}

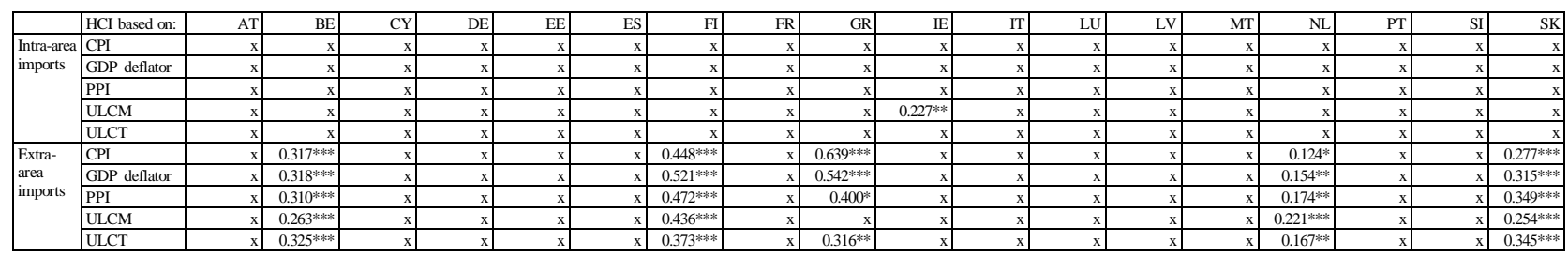

Notes: $* * *, * *$ and $*$ imply significance levels at $1 \%, 5 \%$ and $10 \%$ respectively. $\mathrm{x}$ denotes the absence of value.

An additional dimension to study the robustness of our results is analysing the determinants of imports, excluding energy products. Energy imports are normally found to be price insensitive, which lowers the price elasticity of aggregate imports (see, e.g. Pluyaud (2006)). The exclusion of energy should mainly (if at all) have an impact on extra-euro area imports, as it is part of trade with countries outside the monetary union. Indeed, Table 9 shows that intra-euro area import elasticity to HCIs remains largely unaffected, except for the Netherlands, whose intra-euro area imports now appear sensitive to relative prices. As to the extra-euro area imports, they turn out to be sensitive to HCIs in a larger number of cases, and more importantly in large euro area countries, such as Germany and Italy as well as Austria, Cyprus and Portugal. Finally, comparing the magnitude of the price elasticity of extra-euro area imports with and without the energy component, it is found to be on average larger in the case of imports excluding energy.

\footnotetext{
${ }^{20}$ Input-output tables (from Eurostat) for the year 2005 are available for all countries except Cyprus, Luxembourg, Latvia and Malta.

${ }^{21}$ The results are available upon request.
} 
Table 9

Elasticity of imports with respect to HCIs using energy adjusted imports

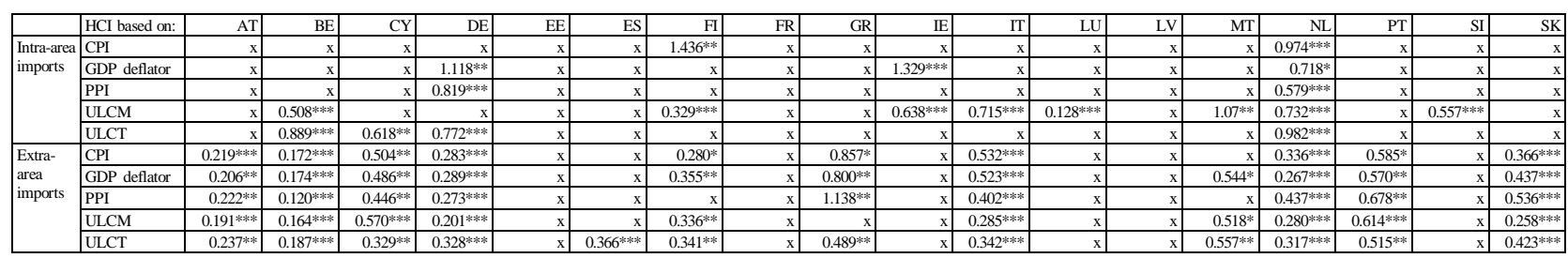

Notes: $* * *, * *$ and $*$ imply significance levels at $1 \%, 5 \%$ and $10 \%$ respectively. $\mathrm{x}$ denotes the absence of value.

Overall, when judging by the number of significant HCIs in import equations, it appears that price/cost competitiveness is a relatively more important driver of extraeuro area imports than intra-euro area imports. However, where significant, the magnitude of HCI elasticity is larger for intra-euro area imports, even when the energy component has been excluded. Finally, extra-euro area imports are found to be more price elastic when energy is excluded in line with the implications in Pluyaud (2006). The global financial crisis appears to have changed the relationship between imports and relative prices; intra-euro area imports appear on average more price sensitive pre-crisis, whereas the number of countries for which extra-euro area imports are price elastic was larger prior to the first quarter of 2008.

\section{Which HCI is better? Results of encompassing test}

Judging based on the significance of HCIs for trade flows, there is no clear evidence supporting the fact that a certain HCI outperforms the others in a systematic fashion. In order to investigate this matter further, we assess the relative performance of different HCIs in explaining export and import volumes by applying an encompassing test similar to the one developed by Marsh and Tokarick (1996), and Clostermann (1998), and applied in a modified version by Ca' Zorzi and Schnatz (2007). We start with cointegration relationships where an HCI was found to be significant and add another price competitiveness indicator as an additional explanatory variable. We reestimate long-run equations with two HCIs being included simultaneously and report the level of significance and the sign of the coefficient both of the original HCI and an additional one. For the same pair of HCIs, we implement this procedure twice, for both equations including each $\mathrm{HCI}^{22}$. Four alternative outcomes are possible:

1) Original indicator appears significant and is correctly signed, whereas additional one is insignificant or wrongly signed.

2) Original indicator is insignificant or wrongly signed, while additional one is significant and correctly signed.

3) Both indicators are significant and correctly signed.

4) Neither indicator is significant and correctly signed.

In the first case, we conclude that the original indicator outperforms the additional one in the cointegration relationship, i.e. the additional regressor does not contain any information regarding export or import volume developments that have not been already captured by the original one. The opposite applies in the second case, i.e. the

\footnotetext{
${ }^{22}$ For example, we start with the CPI-based HCI and include the ULCM-based one as an additional regressor, but we also perform this procedure the other way around (by starting with the equation including the ULCMbased HCI and adding the CPI-based one). In some cases, we have a different set of dummies included in different cointegration relationships, hence the specifications might differ across different HCIs for the same country and trade flow.
} 
additional HCI dominates the original one. Cases 3 and 4 do not allow us to distinguish between the indicators, as either both contain some relevant information (case 3) or both encompass the same information for export and import volume developments (case 4).

In a large number of such bilateral tests, the two indicators are found to capture the same information, as both are found either insignificant or incorrectly signed simultaneously (case 4). In a minor number of cases, the two indicators are found to complement each other (case 3). A short summary of bilateral encompassing test results is presented in Table 10. We classify an indicator to be the "best", if it is superior to all other indicators according to bilateral tests explained above. If two indicators are found to capture the same information (case 3), but outperform the rest of indicators, we classify them both as "best" (and we show both of them in Table 10).

Table 10

Summary of encompassing bilateral test results

\begin{tabular}{|c|c|c|c|c|}
\hline & Intra-euro area exports & $\begin{array}{l}\text { Extra-euro area } \\
\text { exports }\end{array}$ & Intra-euro area imports & $\begin{array}{l}\text { Extra-euro area } \\
\text { imports }\end{array}$ \\
\hline Austria & & ULCM and ULCT & ULCM & \\
\hline Belgium & CPI & PPI & & PPI \\
\hline Cyprus & & ULCM and ULC & PPI & ULCM \\
\hline Germany & & ULCM & & \\
\hline Estonia & ULCT & PPI & & \\
\hline Spain & ULCT & ULCM & & $\mathrm{x}$ \\
\hline Finland & & PPI & ULCM & CPI and GDP \\
\hline France & & ULCM & & \\
\hline Greece & GDP & ULCM and ULCT & & $x$ \\
\hline Ireland & ULCM & CPI & ULCM & \\
\hline Italy & ULCT & ULCM & & \\
\hline Luxembourg & & & ULCT & \\
\hline Latvia & & GDP & & \\
\hline Malta & & & ULCM & ULCT \\
\hline Netherlands & GDP and ULCT & $x$ & & GDP and ULCM \\
\hline Portugal & & ULCM & GDP & \\
\hline Slovenia & & $\mathrm{x}$ & & \\
\hline Slovakia & & & & ULCT \\
\hline
\end{tabular}

Notes: Blank cells refer to cases where none of the HCIs has an explanatory power. Cases denoted by x show that none of the HCIs was found to be dominant with respect to the rest.

Indicators of cost competitiveness and even more so ULCM-based HCIs appear to contain some extra information for trade flows as compared to the other considered measures. This holds true especially in the case of exports outside the euro area. However, in the case of intra-euro area exports, broad price-based HCIs (namely CPI, GDP deflator and ULCT) appear as "best". Hence, cost moderation both in the tradable and non-tradable sectors would be needed to reap competitiveness gains within the euro area. However, at the same time, poorer significance of cost/price competitiveness for intra-euro area exports in the wake of the crisis implies that other measures aimed at fostering non-price competitiveness should be pursued.

As regards the relatively lower information content encompassed by the CPI-based HCIs, which are frequently employed in empirical analyses, this may reflect the 
impact of changes in indirect taxation which has no effect on exports. Furthermore, CPI-based HCIs account for variation in the price level of goods and services not subject to international trade. 


\section{CONCLUSIONS}

This study examines the effect of price competitiveness (as measured by alternative available competitiveness indicators) on exports and imports of euro area member states within and outside the monetary union. It also compares the performance of alternative measures of price competitiveness in their ability to explain trade flows.

Estimation results suggest that price competitiveness is more important for exports than imports (even when energy imports are excluded). The effect on exports is more evident outside the monetary union, as indicated by the larger number of specifications for which extra-euro area exports are found to be sensitive to relative prices compared to intra-euro area exports. When employing a shorter pre-crisis sample, the number of specifications where price competitiveness measure appears significant for intra-euro area exports is larger as compared to the full sample. Furthermore, where significant, the magnitude of relative price effect is larger for intra-euro area exports (both for the pre-crisis and the full sample), in line with the previous literature which normally covers the time span before the crisis. Hence, the global financial crisis may have distorted the standard relationship between exports and relative prices within the euro area, which can reflect a temporary fall-back in integration of euro area countries into global value chains during the crisis, the role of falling domestic demand in stimulating exporting activities, and the effect of recent indirect tax increases on price competitiveness measures. This remains subject to future research.

Price competitiveness appears to be less important for imports, largely due to the increasing integration of the euro area in global value chains and the inclusion of relatively inelastic energy imports in the aggregate import data. The number of specifications for which imports are price elastic is found to be larger for extra-euro area imports. When import flows net of energy are employed, extra-euro area imports are found to be price elastic in more euro area countries confirming the results of the previous literature. Finally, the standard relationship between imports and price competitiveness might have changed over the crisis: estimation of the pre-crisis period indicates that extra-euro area imports are price elastic in a larger number of specifications than in the full sample. The lower number of countries for which the price elasticity is significant over the full sample might be explained by increasing quality of imported inputs required for the production of higher quality exports.

Based on the significance of various measures of price/cost competitiveness, it is difficult to single out one particular measure that outperforms the others. The employed encompassing test suggests that relative labour costs appear to have higher information content for trade flows, in particular for exports outside the euro area. Broad price-based HCIs (namely, CPI, GDP deflator and ULCT) appear superior in the case of intra-euro area exports.

The main policy conclusion rests on the results that relative prices and costs play an important role for trade flows to countries outside the euro area, whereas relative price and cost adjustment has more limited effects on the rebalancing process within the euro area. This suggests that additional measures, such as structural reforms, including those in domestic product and labour markets and those driving non-price competitiveness, should be pursued in the deficit countries besides those aiming at price and cost adjustment. 


\section{APPENDIX}

Table Al

Summary of findings concerning intra-euro area and extra-euro area trade

\begin{tabular}{|c|c|c|c|}
\hline Study & $\begin{array}{l}\text { Countries and } \\
\text { sample }\end{array}$ & $\begin{array}{l}\text { Econometric model and included } \\
\text { variables }\end{array}$ & Conclusions \\
\hline \multicolumn{4}{|c|}{ Standard intra-euro area and extra-euro area export and import equations } \\
\hline Stahn (2006) & $\begin{array}{l}\text { Germany, } \\
\text { Q1 1980- } \\
\text { Q3 } 2004 \text { (but also } \\
\text { a shorter sample } \\
\text { starting 1993) }\end{array}$ & $\begin{array}{l}\text { ECM: intra/extra-euro area exports, real } \\
\text { demand in export markets, total sales } \\
\text { deflator, dummies }\end{array}$ & $\begin{array}{l}\text { Relative price elasticity of } 0.9 / 0.6 \text { for } \\
\text { intra-euro area exports versus } 0.6 / 0.7 \\
\text { for extra-euro area exports in a long } \\
\text { sample (depending on the estimation } \\
\text { approach chosen). The effect of price } \\
\text { competitiveness is statistically } \\
\text { insignificant in the short sample. }\end{array}$ \\
\hline $\begin{array}{l}\text { Pluyaud } \\
\text { (2006) }\end{array}$ & $\begin{array}{l}\text { France, Q3 1989- } \\
\text { Q4 } 2004\end{array}$ & $\begin{array}{l}\text { ECM: intra/extra-euro area exports, real } \\
\text { demand in export markets, ratio of } \\
\text { competitor prices to export prices, linear } \\
\text { trend, dummies } \\
\text { ECM: intra/extra-euro area imports, } \\
\text { import content of domestic demand, ratio } \\
\text { of French production prices to import } \\
\text { prices, linear trend, dummies }\end{array}$ & $\begin{array}{l}\text { Relative price elasticity of } 0.9 \text { for intra- } \\
\text { euro area exports versus } 0.5 \text { for extra- } \\
\text { euro area exports. } \\
\text { Relative price elasticities of intra-euro } \\
\text { area imports versus extra-euro area non- } \\
\text { energy imports ( } 2.2 \text { versus } 1.7 \text { when } \\
\text { demand elasticity is restricted to be } \\
\text { equal to unity, and } 0.7 \text { versus } 0.8 \text { when } \\
\text { demand elasticity is not restricted). } \\
\text { Extra-euro area energy imports are } \\
\text { insensitive to relative prices. }\end{array}$ \\
\hline $\begin{array}{l}\text { Bayoumi et } \\
\text { al. (2011) }\end{array}$ & $\begin{array}{l}\text { Panel of } 11 \text { euro } \\
\text { area countries, } \\
1980-2009\end{array}$ & $\begin{array}{l}\text { Panel ECM: intra/extra-euro area } \\
\text { manufacturing exports, foreign demand } \\
\text { (real GDP-based), REER (CPI-based } \\
\text { wholesale price index (WPI-based), } \\
\text { export unit values (XUV-based and } \\
\text { ULC-based), dummy, country fixed } \\
\text { effect }\end{array}$ & $\begin{array}{l}\text { Intra-euro area exports are more } \\
\text { sensitive to price competitiveness (price } \\
\text { elasticity ranging from } 0.7 \text { to } 1.3 \text { ) than } \\
\text { extra-euro area exports }(0.1 \text { to } 0.3 \text { ). This } \\
\text { difference has increased since the } \\
\text { inception of the euro. }\end{array}$ \\
\hline $\begin{array}{l}\text { Estrada et al. } \\
(2004)\end{array}$ & Spain & $\begin{array}{l}\text { ECM: intra/extra-euro area exports, real } \\
\text { foreign demand, ratio of competitor } \\
\text { prices to export prices, linear trend, } \\
\text { dummy } \\
\text { ECM: intra-euro area imports (extra-euro } \\
\text { area imports), import content of domestic } \\
\text { demand, ratio of import prices to the } \\
\text { private sector value added deflator, linear } \\
\text { trend, dummy }\end{array}$ & $\begin{array}{l}\text { Relative price elasticity of } 0.9 \text { for intra- } \\
\text { euro area exports versus } 1.1 \text { for extra- } \\
\text { euro area exports. } \\
\text { Relative price elasticity is } 0.5 \text { for both } \\
\text { intra- and extra-euro area imports. }\end{array}$ \\
\hline $\begin{array}{l}\text { Stirböck } \\
(2006)\end{array}$ & $\begin{array}{l}\text { Germany, } \\
\text { Q1 1980- } \\
\text { Q4 } 2004 \text { (but a } \\
\text { shorter sample } \\
\text { starting 1993) }\end{array}$ & $\begin{array}{l}\text { ECM: intra/extra-euro area imports, real } \\
\text { aggregate demand (also decomposed into } \\
\text { total consumption, investment and } \\
\text { exports), REER (based on producer price } \\
\text { deflator, GDP deflator and total sales } \\
\text { deflator), dummy }\end{array}$ & $\begin{array}{l}\text { Relative prices are significant for intra- } \\
\text { euro area imports only ( } 1.3 \text { in a more } \\
\text { recent sample versus } 0.7 \text { over a longer } \\
\text { sample). }\end{array}$ \\
\hline Study & $\begin{array}{l}\text { Countries and } \\
\text { sample }\end{array}$ & $\begin{array}{l}\text { Econometric model and included } \\
\text { variables }\end{array}$ & Conclusions \\
\hline
\end{tabular}




\begin{tabular}{|c|c|c|c|}
\hline \multicolumn{4}{|c|}{ Other relevant studies } \\
\hline $\begin{array}{l}\text { Dieppe and } \\
\text { Warmedinger } \\
(2007)\end{array}$ & $\begin{array}{l}\text { Euro area } \\
\text { aggregate, } \\
\text { Q1 1980- } \\
\text { Q4 } 2004\end{array}$ & $\begin{array}{l}\text { ECM: comprehensive assessment of } \\
\text { trade flows as the trade block of the } \\
\text { ECB's Area-Wide Model (AWM). There } \\
\text { are } 3 \text { equations on the real side: extra- } \\
\text { euro area exports, total imports, the ratio } \\
\text { of intra- to extra-euro area imports and } \\
3 \text { equations for deflators. The rest are } \\
\text { accounting equations. }\end{array}$ & $\begin{array}{l}\text { Over the first two years after a nominal } \\
\text { appreciation of the euro, euro area total } \\
\text { imports tend to be below the baseline. } \\
\text { This reflects the substitution effect } \\
\text { away from intra-euro area imports to } \\
\text { extra-euro area imports, complemented } \\
\text { by a lower domestic activity effect } \\
\text { from currency appreciation. }\end{array}$ \\
\hline $\begin{array}{l}\text { Anderton et } \\
\text { al. }(2005)\end{array}$ & $\begin{array}{l}\text { Euro area } \\
9 \text { countries panel } \\
\text { dataset, } \\
\text { Q1 1989- } \\
\text { Q4 } 2000\end{array}$ & $\begin{array}{l}\text { Three stage least squares: intra-euro area } \\
\text { manufacturing imports (extra-euro area } \\
\text { manufacturing imports), lagged } \\
\text { dependent variable, real total final } \\
\text { expenditure, import price, domestic } \\
\text { producer price, exchange rate volatility, } \\
\text { dummies, fixed country effects }\end{array}$ & $\begin{array}{l}\text { The evidence of a substitution between } \\
\text { intra- and extra-euro area imports due } \\
\text { to a change in their relative price } \\
\text { levels. }\end{array}$ \\
\hline
\end{tabular}

Table A2

Intra- and extra-euro area exports (percent of GDP)

\begin{tabular}{|c|c|c|c|c|c|c|c|c|c|c|}
\hline \multirow[t]{2}{*}{ Country } & \multicolumn{2}{|c|}{2000} & \multicolumn{2}{|c|}{2007} & \multicolumn{2}{|c|}{2013} & \multicolumn{2}{|c|}{$\begin{array}{c}\text { Intra-euro area } \\
\text { exports }\end{array}$} & \multicolumn{2}{|c|}{$\begin{array}{c}\text { Extra-euro area } \\
\text { exports }\end{array}$} \\
\hline & $\begin{array}{r}\text { intra-eurc } \\
\text { are } \\
\text { export }\end{array}$ & $\begin{array}{r}\text { extra-euro } \\
\text { area } \\
\text { exports } \\
\end{array}$ & $\begin{array}{r}\text { intra-euro } \\
\text { area } \\
\text { exports }\end{array}$ & $\begin{array}{r}\text { extra-euro } \\
\text { area } \\
\text { exports } \\
\end{array}$ & $\begin{array}{r}\text { intra-euro } \\
\text { area } \\
\text { exports }\end{array}$ & $\begin{array}{r}\text { extra-euro } \\
\text { area } \\
\text { exports } \\
\end{array}$ & $\begin{array}{r}2007 \text { vs } \\
2000\end{array}$ & $\begin{array}{r}2013 \text { vs } \\
2007\end{array}$ & $\begin{array}{r}2007 \text { vs } \\
2000\end{array}$ & $\begin{array}{r}2013 \text { vs } \\
2007\end{array}$ \\
\hline Austria & 20.5 & 14.7 & 23.8 & 19.8 & 22.3 & 19.7 & 3.3 & -1.5 & 5.0 & -0.1 \\
\hline Belgium & 50. & 30.4 & 58.8 & 34.9 & 52.4 & 39.8 & 8.2 & -6.4 & 4.5 & 4.9 \\
\hline Cyprus & 1. & 2.9 & 3.3 & 3.2 & 3.5 & 5.5 & 1.8 & 0.2 & 0.3 & 2.4 \\
\hline Germany & 13.3 & 15.9 & 17.4 & 22.3 & 14.7 & 25.3 & 4.1 & -2.7 & 6.4 & 3.0 \\
\hline Estonia & 27.3 & 28.9 & 15.8 & 34.3 & 20.5 & 46.2 & -11.5 & 4.7 & 5.4 & 12.0 \\
\hline Spain & 12. & 7.7 & 10.2 & 7.4 & 11.7 & 11.6 & -2.0 & 1.6 & -0.3 & 4.2 \\
\hline Finland & 14.9 & 23.4 & 12.1 & 24.8 & 9.1 & 20.1 & -2.4 & -3.0 & 1.5 & -4.8 \\
\hline France & 12. & 12.1 & 11.1 & 10.6 & 9.9 & 11.3 & -1.5 & -1.2 & -1.6 & 0.8 \\
\hline Greece & 4. & 5.1 & 3.8 & 4.9 & 4.8 & 10.3 & -0.3 & 1.1 & -0.2 & 5.4 \\
\hline Ireland & 32. & 46.9 & 19.2 & 27.4 & 19.2 & 33.0 & -12.9 & 0.0 & -19.5 & 5.6 \\
\hline Italy & 10. & 11.3 & 10.9 & 12.6 & 10.0 & 15.0 & 0.3 & -0.9 & 1.4 & 2.4 \\
\hline Luxembourg & 30.8 & 10.6 & 31.9 & 13.1 & 23.9 & 8.6 & 1.0 & -8.0 & 2.5 & -4.4 \\
\hline Latvia & 8.9 & 15.2 & 10.2 & 18.6 & 14.3 & 32.4 & 1.3 & 4.1 & 3.5 & 13.7 \\
\hline Malta & 15.8 & 45.5 & 14.9 & 30.7 & 12.6 & 24.6 & -1.0 & -2.3 & -14.9 & -6.0 \\
\hline Netherlands & $39 .($ & 21.5 & 42.9 & 27.3 & 49.3 & 33.7 & 4.0 & 6.4 & 5.8 & 6.4 \\
\hline Portugal & 13.8 & 6.9 & 15.1 & 7.5 & 17.2 & 11.4 & 1.3 & 2.1 & 0.6 & 3.9 \\
\hline Slovenia & 26.9 & 17.2 & 33.0 & 30.4 & 38.0 & 34.8 & 6.2 & 5.0 & 13.3 & 4.3 \\
\hline Slovakia & 33.2 & 25.0 & 39.8 & 38.2 & 39.9 & 50.2 & 6.6 & 0.1 & 13.2 & 12.1 \\
\hline
\end{tabular}

Sources: Eurostat and authors' calculations. 
Table A3

Intra- and extra-euro area imports (percent of GDP)

\begin{tabular}{|c|c|c|c|c|c|c|c|c|c|c|}
\hline \multirow[t]{2}{*}{ Country } & \multicolumn{2}{|c|}{2000} & \multicolumn{2}{|c|}{2007} & \multicolumn{2}{|c|}{2013} & \multicolumn{2}{|c|}{$\begin{array}{c}\text { Intra-euro area } \\
\text { exports }\end{array}$} & \multicolumn{2}{|c|}{$\begin{array}{c}\text { Extra-euro area } \\
\text { exports }\end{array}$} \\
\hline & $\begin{array}{r}\text { intra-eur } \\
\text { are } \\
\text { import }\end{array}$ & $\begin{array}{r}\text { extra-euro } \\
\text { area } \\
\text { imports } \\
\end{array}$ & $\begin{array}{r}\text { intra-euro } \\
\text { area } \\
\text { imports }\end{array}$ & $\begin{array}{r}\text { extra-euro } \\
\text { area } \\
\text { imports } \\
\end{array}$ & $\begin{array}{r}\text { intra-euro } \\
\text { area } \\
\text { import }\end{array}$ & $\begin{array}{r}\text { extra-euro } \\
\text { area } \\
\text { imports }\end{array}$ & $\begin{array}{r}2007 \text { vs } \\
2000\end{array}$ & $\begin{array}{r}2013 \text { vs } \\
2007\end{array}$ & $\begin{array}{r}2007 \text { vs } \\
2000\end{array}$ & $\begin{array}{r}2013 \mathrm{vs} \\
2007\end{array}$ \\
\hline Austria & 25. & 12.4 & 29.5 & 13.9 & 27.7 & 16.0 & 4.3 & -1.7 & 1.4 & 2.1 \\
\hline Belgium & 43. & 32.4 & 53.1 & 36.4 & 49.4 & 39.0 & 9.2 & -3.6 & 3.9 & 2.7 \\
\hline Cyprus & 15. & 18.7 & 21.9 & 17.7 & 17.2 & 11.6 & 6.7 & -4.7 & -1.0 & -6.1 \\
\hline Germany & 11. & 14.3 & 14.5 & 17.1 & 14.6 & 18.0 & 2.6 & 0.1 & 2.8 & 0.8 \\
\hline Estonia & 36. & 38.3 & 29.6 & 41.3 & 27.8 & 46.2 & -6.6 & -1.7 & 3.0 & 4.9 \\
\hline Spain & 15. & 11.6 & 14.4 & 12.7 & 11.3 & 13.5 & -0.9 & -3.1 & 1.1 & 0.8 \\
\hline Finland & 11. & 17.2 & 12.8 & 20.4 & 11.5 & 18.6 & 1.8 & -1.3 & 3.2 & -1.8 \\
\hline France & 14. & 11.3 & 14.2 & 10.2 & 14.1 & 10.8 & 0.0 & -0.2 & -1.2 & 0.6 \\
\hline Greece & 13. & 12.6 & 13.0 & 14.0 & 9.5 & 16.4 & -0.8 & -3.5 & 1.4 & 2.4 \\
\hline Ireland & 13. & 38.5 & 9.1 & 23.2 & 8.2 & 21.8 & -4.7 & -0.9 & -15.4 & -1.4 \\
\hline Italy & 10. & 10.8 & 11.4 & 12.7 & 10.3 & 12.8 & 0.6 & -1.1 & 1.9 & 0.0 \\
\hline Luxembourg & 44. & 12.1 & 38.5 & 16.5 & 34.1 & 10.7 & -5.7 & -4.4 & 4.4 & -5.8 \\
\hline Latvia & 19. & 21.9 & 23.8 & 29.7 & 23.5 & 33.7 & 4.6 & -0.3 & 7.8 & 4.0 \\
\hline Malta & 43. & 41.6 & 36.2 & 27.0 & 34.8 & 26.9 & -7.6 & -1.4 & -14.6 & -0.1 \\
\hline Netherlands & 22. & 34.5 & 24.7 & 38.2 & 24.9 & 49.0 & 2.5 & 0.2 & 3.7 & 10.8 \\
\hline Portugal & 23. & 11.1 & 24.7 & 10.7 & 22.5 & 11.7 & 1.7 & -2.3 & -0.4 & 1.0 \\
\hline Slovenia & 32. & 18.4 & 41.8 & 24.8 & 38.2 & 33.1 & 9.2 & -3.6 & 6.4 & 8.4 \\
\hline Slovakia & 28. & 33.7 & 33.7 & 46.7 & 35.5 & 49.8 & 5.0 & 1.8 & 13.0 & 3.1 \\
\hline
\end{tabular}

Sources: Eurostat and authors' calculations. 
Table A4

Current account balances and intra- and extra-euro area goods trade balances (excluding energy) (percent of GDP)

\begin{tabular}{|c|c|c|c|c|c|c|c|c|c|c|c|c|c|c|c|}
\hline \multirow[t]{2}{*}{ Country } & \multicolumn{3}{|c|}{2000} & \multicolumn{3}{|c|}{2007} & \multicolumn{3}{|c|}{2013} & \multicolumn{3}{|c|}{2007 vs 2000} & \multicolumn{3}{|c|}{2013 vs 2007} \\
\hline & $\begin{array}{r}\mathrm{CA} \\
\text { balance }\end{array}$ & $\begin{array}{r}\text { intra- } \\
\text { euro } \\
\text { area } \\
\text { trade } \\
\text { balance }\end{array}$ & $\begin{array}{r}\text { extra- } \\
\text { euro } \\
\text { area } \\
\text { trade } \\
\text { balance }\end{array}$ & $\begin{array}{r}\mathrm{CA} \\
\text { balance }\end{array}$ & $\begin{array}{r}\text { intra- } \\
\text { euro } \\
\text { area } \\
\text { trade } \\
\text { balance }\end{array}$ & $\begin{array}{r}\text { extra- } \\
\text { euro } \\
\text { area } \\
\text { trade } \\
\text { balance }\end{array}$ & $\begin{array}{r}\text { CA } \\
\text { balance }\end{array}$ & \begin{tabular}{|} 
intra- \\
euro \\
area \\
trade \\
balance
\end{tabular} & $\begin{array}{r}\text { extra- } \\
\text { euro } \\
\text { area } \\
\text { trade } \\
\text { balance }\end{array}$ & $\begin{array}{r}\mathrm{CA} \\
\text { balance }\end{array}$ & $\begin{array}{r}\text { intra- } \\
\text { euro } \\
\text { area } \\
\text { trade } \\
\text { balance }\end{array}$ & $\begin{array}{r}\text { extra- } \\
\text { euro } \\
\text { area } \\
\text { trade } \\
\text { balance }\end{array}$ & $\begin{array}{r}\mathrm{CA} \\
\text { balance }\end{array}$ & $\begin{array}{r}\text { intra- } \\
\text { euro } \\
\text { area } \\
\text { trade } \\
\text { balance }\end{array}$ & $\begin{array}{r}\text { extra- } \\
\text { euro } \\
\text { area } \\
\text { trade } \\
\text { balance }\end{array}$ \\
\hline Austri & 1.18 & -4.10 & 3.62 & 6.41 & -4.54 & 7.70 & 6.30 & -4.24 & 6.07 & 5.2 & -0.4 & 4.1 & -0.1 & 0.3 & -1.6 \\
\hline $\mathrm{elg}_{1}$ & & 69 & .12 & & 3 & -0.07 & 3.08 & 10 & 2.23 & -1.3 & -0.7 & 1.0 & -2.6 & -1.9 & 2.3 \\
\hline Cyprus & -1.03 & -13.03 & -12.01 & -6.07 & -16.90 & -10.45 & 5.09 & -10.71 & -2.02 & -5.0 & -3.9 & 1.6 & 11.2 & 6.2 & 8.4 \\
\hline Gern & 0.25 & 1.82 & 3.13 & 9.93 & 3.26 & 7.32 & 11.04 & 1.04 & 9.92 & 9.7 & 1.4 & 4.2 & 1.1 & -2.2 & 2.6 \\
\hline Eston & -2.19 & -8.82 & -6.37 & -12.36 & -13.99 & -3.25 & 1.28 & -8.08 & 3.11 & -10.2 & -5.2 & 3.1 & 13.6 & 5.9 & 6.4 \\
\hline Spain & -1.53 & -3.29 & -1.28 & -6.93 & -3.93 & -2.44 & 4.15 & 0.09 & 1.87 & -5.4 & -0.6 & -1.2 & 11.1 & 4.0 & 4.3 \\
\hline Finlan & 9.80 & 3.23 & 8.39 & 6.85 & -0.94 & 7.28 & 1.63 & -3.44 & 5.30 & -2.9 & -4.2 & -1.1 & -5.2 & -2.5 & -2.0 \\
\hline France & 2.87 & -1.65 & 2.48 & 1.3 & -2.81 & 2.40 & 1.79 & -3.42 & 2.91 & -1.6 & -1.2 & -0.1 & 0. & -0.6 & 0.5 \\
\hline & -5.78 & -9.82 & -5.39 & -11.63 & -9.35 & -5.98 & 4.21 & -5.10 & -2.19 & -5.9 & 0.5 & -0.6 & 15.8 & 4.3 & 3.8 \\
\hline Irela & 1.52 & 18.50 & 10.16 & -2.89 & 10.42 & 6.44 & 10.09 & 11.16 & 14.66 & -4.4 & -8.1 & -3.7 & 13.0 & 0.7 & 8.2 \\
\hline Italy & 1.42 & -0.37 & 2.19 & 1.69 & -0.66 & 3.03 & 4.42 & -0.14 & 5.48 & 0.3 & -0.3 & 0.8 & 2.7 & 0.5 & 2.5 \\
\hline & 16.71 & -9.85 & -1.48 & 15.34 & -1.38 & -3.42 & 10.74 & -4.63 & -2.05 & -1.4 & 8.5 & -1.9 & -4.6 & -3.2 & 1.4 \\
\hline Latvic & -0.41 & -10.06 & -2.58 & -17.74 & -13.80 & -6.29 & 4.63 & -8.62 & 3.51 & -17.3 & -3.7 & -3.7 & 22.4 & 5.2 & 9.8 \\
\hline Malta & -8.81 & -23.60 & 2.97 & -4.65 & -18.14 & 1.99 & 11.22 & -14.14 & -0.54 & 4.2 & 5.5 & -1.0 & 15.9 & 4.0 & -2.5 \\
\hline & 2.63 & 13.10 & -8.75 & 8.00 & 13.63 & -5.04 & 11.87 & 16.42 & -5.88 & 5.4 & 0.5 & 3.7 & 3.9 & 2.8 & -0.8 \\
\hline Por & -7.38 & -8.58 & -1.86 & -6.34 & -8.92 & -0.19 & 4.27 & -5.26 & 3.46 & 1.0 & -0.3 & 1.7 & 10.6 & 3.7 & 3.6 \\
\hline & 1.66 & -4.21 & 1.57 & 0.58 & -6.38 & 8.03 & 11.94 & 1.40 & 5.69 & -1.1 & -2.2 & 6.5 & 11.4 & 7.8 & -2.3 \\
\hline slovakia & 3.53 & 3.66 & -0.98 & -0.31 & 5.27 & -2.74 & 8.20 & 3.30 & 7.62 & -3.8 & 1.6 & -1.8 & 8.5 & -2.0 & 10.4 \\
\hline
\end{tabular}

Sources: Eurostat and authors' calculations.

\section{Chart Al(a)}

Decomposition of ULCT-based HCIs

(percentage change Q1 2000-Q4 2007; contributions in percentage points)

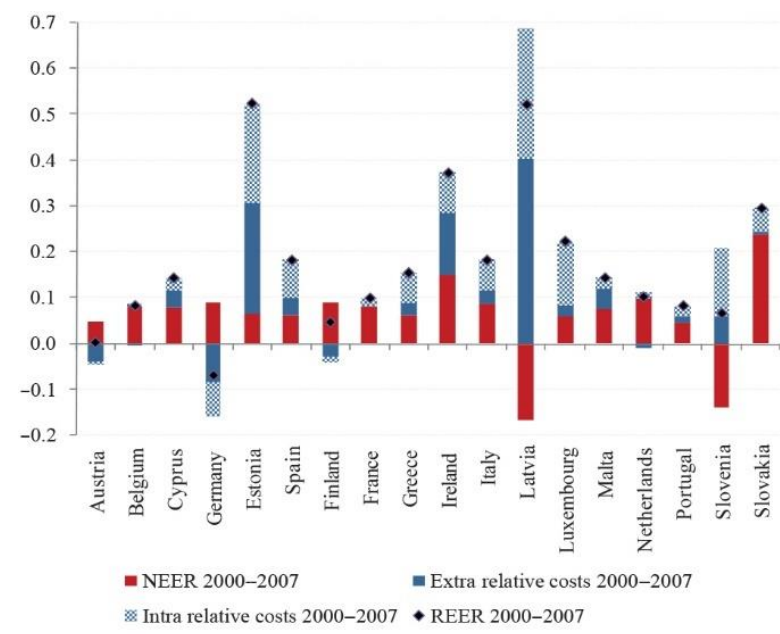

Sources: ECB and authors' calculations.

\section{Chart Al(b)}

Decomposition of ULCT-based HCIs

(percentage change Q1 2008-Q4 2013; contributions in percentage points)

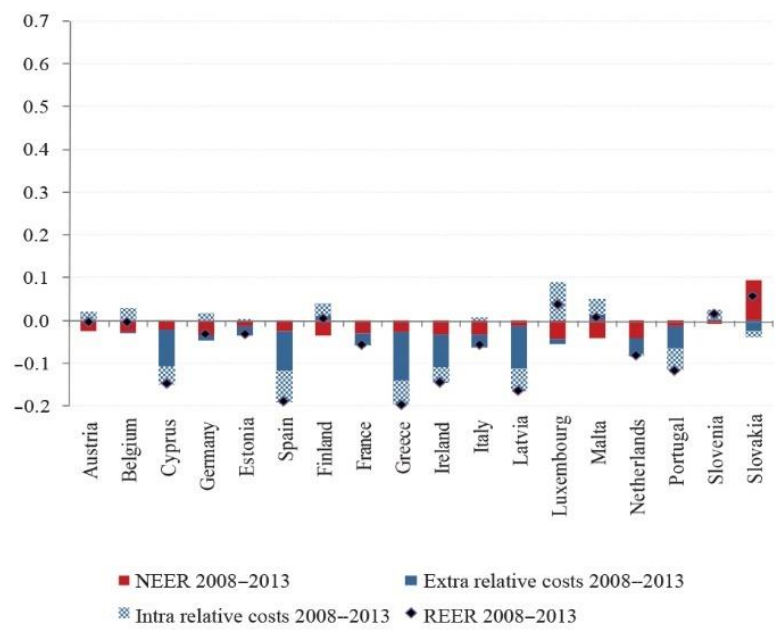

Sources: ECB and authors' calculations. 
Chart A2(a)

Decomposition of GDP-based HCIs

(percentage change Q1 2000-Q4 2007; contributions in percentage points)

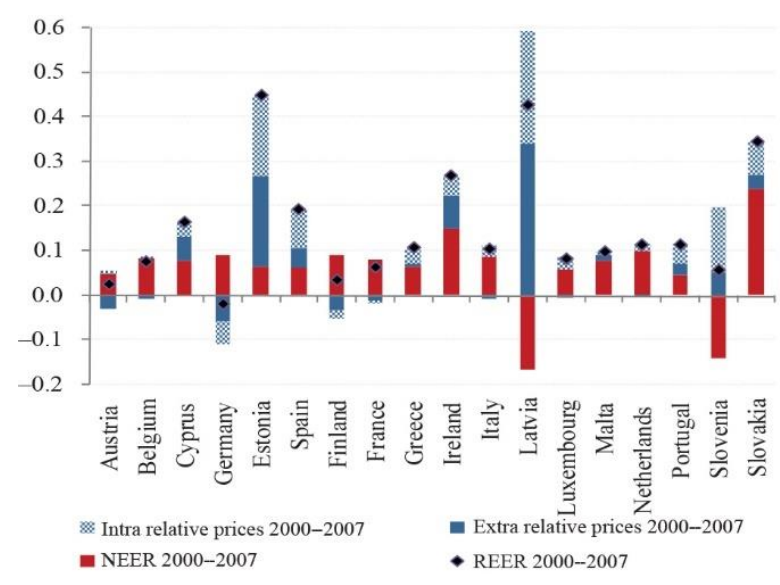

Sources: ECB and authors' calculations.

Chart A3(a)

Decomposition of PPI-based HCIs

(percentage change Q1 2000-Q4 2007; contributions in percentage points)

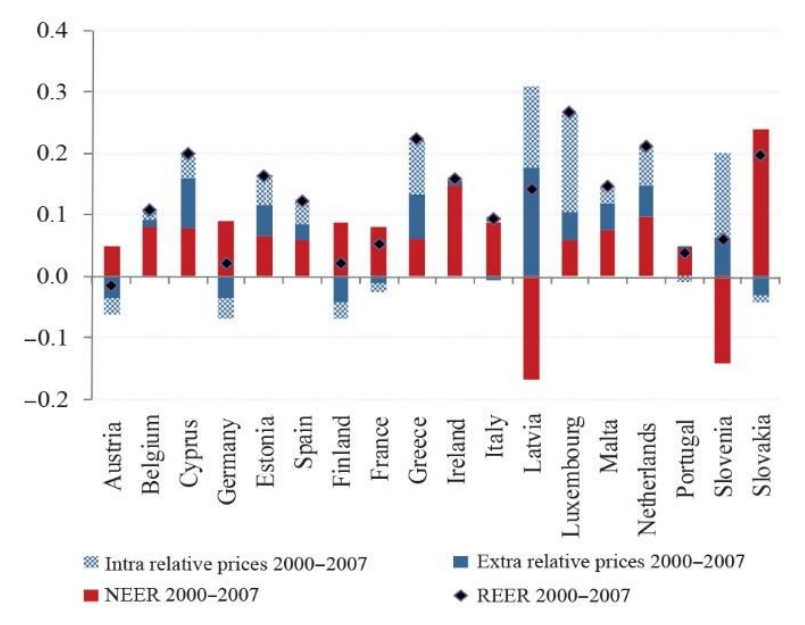

Sources: ECB and authors' calculations.
Chart A2(b)

Decomposition of GDP-based HCIs

(percentage change Q1 2008-Q4 2013; contributions in percentage points)

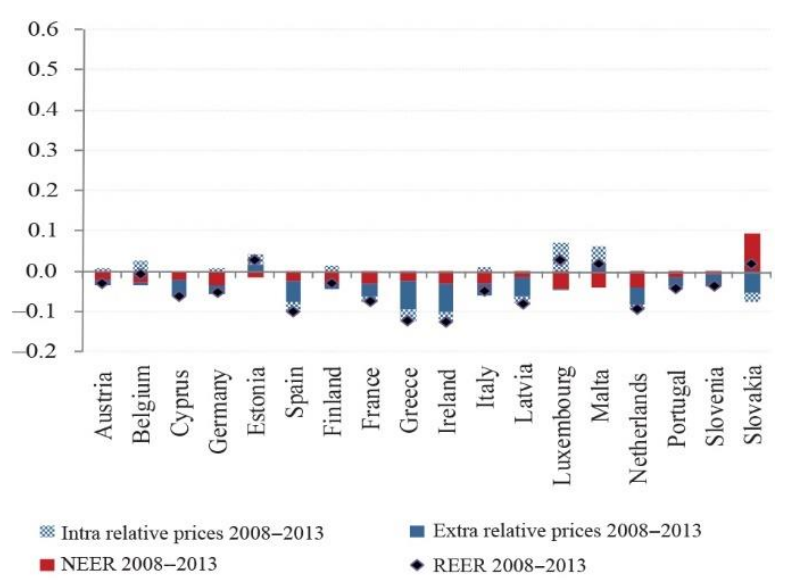

Sources: ECB and authors' calculations.

Chart A3(b)

Decomposition of PPI-based HCIs

(percentage change Q1 2008-Q4 2013; contributions in percentage points)

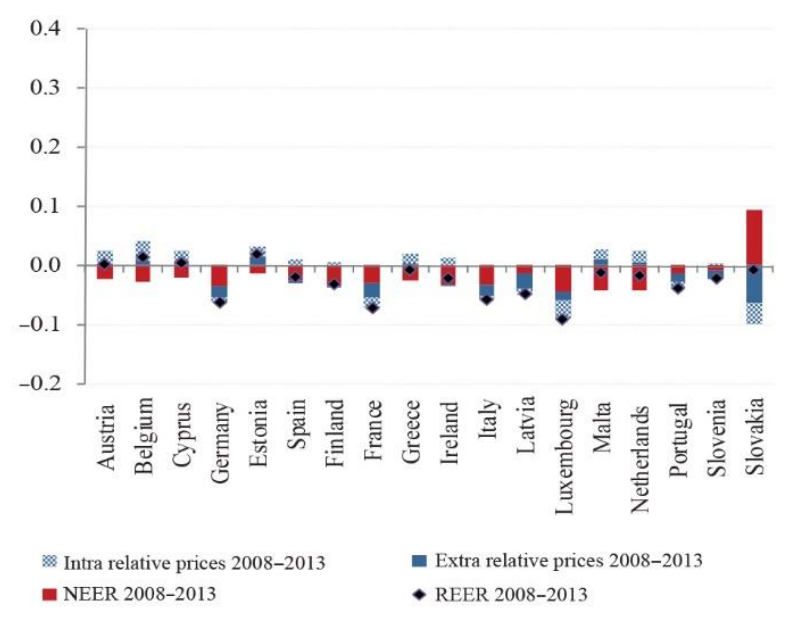

Sources: ECB and authors' calculations. 
Table A5

Intra-euro area export estimation results using CPI-deflated HCI

\begin{tabular}{|c|c|c|c|c|c|c|c|c|c|c|c|c|c|c|c|c|c|c|}
\hline & $\mathrm{AT}$ & $\mathrm{BE}$ & $\mathrm{CY}$ & $\mathrm{DE}$ & $\mathrm{EE}$ & ES & $\mathrm{FI}$ & FR & GR & IE & IT & $\mathrm{LU}$ & LV & MT & $\mathrm{NL}$ & PT & SI & SK \\
\hline Const & $\mathrm{x}$ & $9.940^{* * *}$ & $\mathrm{x}$ & $3.650^{* * *}$ & $4.065^{* * *}$ & $\mathrm{x}$ & $3.836 * * *$ & $\mathrm{x}$ & $3.752^{* * *}$ & $\mathrm{x}$ & $\mathrm{x}$ & $\mathrm{x}$ & $4.513^{* * *}$ & $\mathrm{x}$ & $10.011^{* * *}$ & $3.888^{* * *}$ & $3.319^{* * *}$ & $\mathrm{x}$ \\
\hline FD & $\mathrm{x}$ & $0.832^{* * *}$ & $\mathrm{x}$ & $1.095^{* * *}$ & $0.401 *$ & $\mathrm{x}$ & $1.433^{* * *}$ & $\mathrm{x}$ & $1.221^{* * *}$ & $\mathrm{x}$ & $\mathrm{x}$ & $\mathrm{x}$ & $1.016^{* * *}$ & $\mathrm{x}$ & $0.648^{* * *}$ & $0.908 * * *$ & $1.534 * * *$ & $\mathrm{x}$ \\
\hline $\mathrm{HCI}$ & $x$ & $-1.322 * *$ & $\mathrm{x}$ & $x$ & $\mathrm{x}$ & $\mathrm{x}$ & $\mathrm{x}$ & $x$ & $\mathrm{x}$ & $x$ & $x$ & $x$ & $\mathrm{x}$ & $\mathrm{x}$ & $-1.34 * * * *$ & $\mathrm{x}$ & $\mathrm{x}$ & $\mathrm{x}$ \\
\hline$\Delta \mathrm{EX}(\mathrm{t}-1)$ & & & & & & & & $-0.407 * * *$ & & $-0.254^{* * * *}$ & $-0.274^{* * * *}$ & & & $-0.416^{* * *}$ & $0.114 * *$ & & & \\
\hline$\Delta \mathrm{EX}(\mathrm{t}-2)$ & & & & & $0.217^{* *}$ & & & & & & $0.152^{* *}$ & & & $-0.290^{* *}$ & & & & \\
\hline$\Delta \operatorname{EX}(\mathrm{t}-3)$ & & & & & & & & $0.315^{* * *}$ & & $-0.191 * *$ & & & & & & & & \\
\hline$\Delta \mathrm{EX}(\mathrm{t}-4)$ & $0.206 * *$ & & $0.219^{*}$ & & & & & $0.297 * * *$ & & & & & & & & & & \\
\hline$\Delta \mathrm{FD}(\mathrm{t})$ & $1.258 * * *$ & $0.656^{* * *}$ & & $1.402 * * *$ & $0.844 * * *$ & $1.237 * * *$ & $1.132 * * *$ & $1.326^{* * * *}$ & $1.004 * * *$ & & $1.170^{* * *}$ & $0.984 * *$ & $1.116^{* * *}$ & $1.752^{* *}$ & $0.837 * * *$ & $1.135 * * *$ & $1.239 * * *$ & $1.293 * * *$ \\
\hline$\Delta \mathrm{FD}(\mathrm{t}-1)$ & & & & & & $-0.454^{* *}$ & & & & & & & & & & & & \\
\hline$\Delta \mathrm{FD}(\mathrm{t}-2)$ & $-0.429 * *$ & & & & & & & & & & & $-0.669 *$ & & & & & & \\
\hline$\Delta \mathrm{FD}(\mathrm{t}-3)$ & & & & & & & & $-0.659^{* * *}$ & & & & & $-0.557 * * *$ & & & & & \\
\hline$\Delta \mathrm{FD}(\mathrm{t}-4)$ & & & & & & & & & & & & & & & & & & \\
\hline$\Delta \mathrm{HCI}(\mathrm{t})$ & & & & & & & & & & & & & & & & & & \\
\hline$\Delta \mathrm{HCI}(\mathrm{t}-1)$ & & & & & & & & & & & & & & & & & & \\
\hline$\Delta \mathrm{HCI}(\mathrm{t}-2)$ & & $-1.065 *$ & & & & & & & & & & & & & & & & \\
\hline$\Delta \mathrm{HCI}(\mathrm{t}-3)$ & & & & & & & & & & & & & & & & & & \\
\hline$\Delta \mathrm{HCI}(\mathrm{t}-4)$ & & & & & & & & & & & & & & & & & & \\
\hline $\operatorname{ECM}(t-1)$ & $\mathrm{x}$ & $-0.426 * * *$ & $\mathrm{x}$ & $-0.531 * * *$ & $-0.274^{* * *}$ & $\mathrm{x}$ & $-0.488 * * *$ & $\mathrm{x}$ & $-0.698 * * *$ & * $x$ & $\mathrm{x}$ & $\mathrm{x}$ & $-0.264^{* *}$ & $\mathrm{x}$ & $-0.605 * * *$ & $-0.373 * * *$ & $-0.608 * * *$ & $\mathrm{x}$ \\
\hline AdjR2 & 0.451 & 0.556 & 0.366 & 0.727 & 0.582 & 0.415 & 0.411 & 0.722 & 0.629 & 0.379 & 0.720 & 0.549 & 0.539 & 0.174 & 0.686 & 0.571 & 0.733 & 0.441 \\
\hline $\mathrm{JB}$ & 0.990 & 3.044 & 1.153 & 2.612 & 0.833 & 0.831 & 1.097 & 1.856 & 0.890 & 0.728 & 1.397 & 1.457 & 2.051 & 0.988 & 0.403 & 0.922 & 0.601 & 0.837 \\
\hline Wald(FD) & $\mathrm{x}$ & $-1.769 *$ & $\mathrm{x}$ & 1.405 & $-2.884^{* * *}$ & $\mathrm{x}$ & $2.653 * * *$ & $\mathrm{x}$ & 1.136 & $\mathrm{x}$ & $\mathrm{x}$ & $\mathrm{x}$ & 0.145 & $\mathrm{x}$ & $-3.166^{* * *}$ & -0.678 & $22.808 * * *$ & $\mathrm{x}$ \\
\hline LM (4) & 1.012 & 0.326 & 1.678 & 1.371 & 0.675 & 0.483 & 0.014 & 0.725 & 2.300 & 0.229 & 0.133 & 0.247 & 0.237 & 0.493 & 0.030 & 0.840 & 1.922 & 0.573 \\
\hline
\end{tabular}

Notes: $* * *, * *$ and $*$ imply significance levels at $1 \%, 5 \%$ and $10 \%$ respectively. $\mathrm{x}$ denotes the absence of value.

Table A6

Extra-euro area export estimation results using CPI-deflated HCI

\begin{tabular}{|c|c|c|c|c|c|c|c|c|c|c|c|c|c|c|c|c|c|c|}
\hline & AT & $\mathrm{BE}$ & $\mathrm{CY}$ & DE & $\mathrm{EE}$ & ES & FI & FR & GR & IE & IT & $\mathrm{LU}$ & LV & MT & $\mathrm{NL}$ & PT & SI & SK \\
\hline \begin{tabular}{|l|} 
Const \\
\end{tabular} & $6.201 * * * *$ & $5.769^{* * * *}$ & $7.717 * * *$ & $4.960^{* * *}$ & $10.890^{* * * *}$ & $5.789^{* * * *}$ & $4.690^{* * * *}$ & $6.987 * * *$ & $6.821 * * *$ & $8.011 * * *$ & $6.140^{* * * *}$ & $\mathrm{x}$ & $7.452 * * *$ & $3.896 * * *$ & $4.226 * * *$ & $4.696 * * *$ & $5.035 * * *$ & $3.238^{* * *}$ \\
\hline FD & $0.992^{* * * *}$ & $0.780^{* * * *}$ & $1.387^{* * * *}$ & $1.129 * * *$ & $1.253 * * *$ & $0.885^{* * * *}$ & $1.130^{* * *}$ & $0.660^{* * * *}$ & $0.578^{* * * *}$ & $\mathrm{x}$ & $0.975^{* * * *}$ & $\mathrm{x}$ & $1.185^{* * * *}$ & $1.531^{* * *}$ & $1.056 * * *$ & $1.127 * * *$ & $1.184^{* * * *}$ & $1.364 * * *$ \\
\hline $\mathrm{HCI}$ & $-0.610^{* * * *}$ & $-0.391 * * *$ & $-0.904^{* * *}$ & $-0.281 * * *$ & $-1.966 * * * *$ & $-0.440^{* * * *}$ & $-0.240^{*}$ & $-0.670 * * *$ & $-0.630^{* * * *}$ & $-1.032 * * *$ & $-0.494 * * *$ & $x$ & $-0.489 * * *$ & $x$ & $-0.166^{* * * *}$ & $-0.147 *$ & $-0.418^{* * * *}$ & $x$ \\
\hline$\Delta \mathrm{EX}(\mathrm{t}-1)$ & & $-0.213^{* *}$ & $-0.288 * *$ & & & & & & $-0.167^{*}$ & $0.297 * * *$ & & & & & & $-0.181 *$ & & \\
\hline$\Delta \mathrm{EX}(\mathrm{t}-2)$ & & $-0.165 * *$ & & & $0.288^{* * * *}$ & & & & & & & & & & & & & \\
\hline$\Delta \operatorname{EX}(\mathrm{t}-3)$ & $0.146 * *$ & & & & & & $-0.193^{* *}$ & & & & & & & & & & & \\
\hline$\Delta \mathrm{EX}(\mathrm{t}-4)$ & & & & & & $-0.265 * * *$ & $0.267 * * *$ & $0.158^{* * *}$ & & & & & & & & & & \\
\hline$\Delta \mathrm{FD}(\mathrm{t})$ & $1.180^{* * * *}$ & $1.543^{* * * *}$ & & $1.303^{* * * *}$ & 1.015 **** & $1.094 * * *$ & $1.091^{* * * *}$ & $1.002^{* * * *}$ & $0.899 * * *$ & & $1.149^{* * * *}$ & $1.111^{* * * *}$ & $0.833^{* * *}$ & $2.371^{* * * *}$ & $1.138^{* * * *}$ & $1.159^{* * * *}$ & $1.122 * * *$ & $0.905 * * *$ \\
\hline$\Delta \mathrm{FD}(\mathrm{t}-1)$ & & & & & & & & & $-0.864^{* * *}$ & & & & & & & & & \\
\hline$\Delta \mathrm{FD}(\mathrm{t}-2)$ & & & & & & & $0.694^{* * * *}$ & & & & & & & & & & & \\
\hline$\Delta \mathrm{FD}(\mathrm{t}-3)$ & & & & & & & & & & & & & & & & & & \\
\hline$\Delta \mathrm{FD}(\mathrm{t}-4)$ & & & & & & $0.298^{*}$ & $-0.919^{* * * *}$ & & & & & $0.718^{*}$ & & & & & & \\
\hline$\Delta \mathrm{HCI}(\mathrm{t})$ & & & & & $-1.204 * *$ & & & $-0.484^{* * * *}$ & $-0.725^{* * *}$ & & & & $-0.498^{*}$ & & & & & \\
\hline$\Delta \mathrm{HCI}(\mathrm{t}-1)$ & & & & & & & & & & & & & & & & & & \\
\hline$\Delta \operatorname{HCI}(\mathrm{t}-2)$ & & & & & & $-0.261 * *$ & & & $-0.654^{* * * *}$ & & & & & & $-0.309 * * *$ & & & \\
\hline$\Delta \mathrm{HCI}(\mathrm{t}-3)$ & & & & & & & & & & & & & & & & & & \\
\hline$\Delta \mathrm{HCI}(\mathrm{t}-4)$ & & & & & & & & & & & & & & & & & & \\
\hline $\operatorname{ECM}(t-1)$ & $-0.286^{* * * *}$ & $-0.381^{* * * *}$ & $-0.336^{* * * *}$ & $-0.589^{* * * * *}$ & $-0.516^{* * * *}$ & $-0.207^{* *}$ & $-0.430^{* * * *}$ & $-0.477^{* * * *}$ & $-0.664^{* * * *}$ & $-0.745^{* * * *}$ & $-0.484 * * * *$ & $\mathrm{x}$ & $-0.636^{* * * *}$ & $-0.641^{* * * *}$ & $-0.804^{* * * *}$ & $-0.446^{* * * *}$ & $-0.439^{* * * *}$ & $-0.232^{* *}$ \\
\hline \begin{tabular}{|l|} 
AdjR2 \\
\end{tabular} & 0.615 & 0.549 & 0.666 & 0.690 & 0.540 & 0.564 & 0.777 & 0.613 & 0.523 & 0.321 & 0.554 & 0.263 & 0.513 & 0.404 & 0.758 & 0.461 & 0.688 & 0.377 \\
\hline $\mathrm{JB}$ & 0.592 & 0.553 & 1.442 & 0.762 & 0.683 & 0.115 & 0.772 & 0.419 & 0.104 & $4.714 *$ & 2.229 & 0.936 & 0.153 & 2.321 & 2.588 & 1.889 & 1.469 & 0.213 \\
\hline Wald(FD) & -0.079 & -1.511 & $2.740^{* * *}$ & $1.791^{*}$ & 1.452 & -0.863 & 1.134 & $-3.183^{* * *}$ & $-3.359^{* * *}$ & $\mathrm{x}$ & -0.242 & $\mathrm{x}$ & $1.835^{*}$ & 1.315 & 1.152 & 0.868 & $2.733^{* * * *}$ & $2.577^{* * *}$ \\
\hline LM(4) & 1.662 & 1.900 & 0.473 & 0.089 & 1.864 & 0.457 & 1.172 & 1.825 & 1.617 & 0.404 & 1.762 & 1.462 & 1.633 & 1.115 & 1.210 & 0.493 & 0.993 & 1.695 \\
\hline
\end{tabular}

Notes: $* * *, * *$ and $*$ imply significance levels at $1 \%, 5 \%$ and $10 \%$ respectively. $\mathrm{x}$ denotes the absence of value. 
Table A7

Intra-euro area export estimation results using GDP-deflated HCI

\begin{tabular}{|c|c|c|c|c|c|c|c|c|c|c|c|c|c|c|c|c|c|c|}
\hline & AT & $\mathrm{BE}$ & $\mathrm{CY}$ & $\mathrm{DE}$ & EE & ES & FI & FR & GR & IE & IT & LU & LV & MT & $\mathrm{NL}$ & PT & SI & SK \\
\hline Const & $\mathrm{x}$ & $\mathrm{x}$ & $\mathrm{x}$ & $3.650^{* * *}$ & $4.065^{* * * *}$ & $\mathrm{x}$ & $3.836^{* * * *}$ & $\mathrm{x}$ & $8.476^{* * * *}$ & $\mathrm{x}$ & $\mathrm{x}$ & $\mathrm{x}$ & $4.513^{* * * *}$ & $\mathrm{x}$ & $10.776^{* * * *}$ & $3.888^{* * * *}$ & $3.319^{* * * *}$ & $\mathrm{x}$ \\
\hline FD & $\mathrm{x}$ & $0.798^{* * * *}$ & $\mathrm{x}$ & $1.095^{* * *}$ & $0.401 *$ & $\mathrm{x}$ & $1.433^{* * *}$ & $\mathrm{x}$ & 1. $149^{* * * *}$ & $\mathrm{x}$ & $\mathrm{x}$ & $\mathrm{x}$ & $1.016^{* * * *}$ & $\mathrm{x}$ & $0.777^{* * *}$ & $0.908^{* * * *}$ & $1.534 * * *$ & $\mathrm{x}$ \\
\hline $\mathrm{HCl}$ & $\mathrm{x}$ & $-1.673^{* * *}$ & $x$ & $\mathrm{x}$ & $\mathrm{x}$ & $\mathrm{x}$ & $\mathrm{x}$ & $x$ & $-1.038^{* * * *}$ & $\mathrm{x}$ & $\mathrm{x}$ & $\mathrm{x}$ & $x$ & $\mathrm{x}$ & $-1.534^{* * * *}$ & $x$ & $x$ & $\mathrm{x}$ \\
\hline$\Delta \mathrm{EX}(\mathrm{t}-1)$ & & & & & & & & $-0.407 * * *$ & & $-0.254^{* * * *}$ & $-0.274^{4 * * *}$ & & & $-0.416^{* * *}$ & $0.102^{*}$ & & & \\
\hline$\Delta \mathrm{EX}(\mathrm{t}-2)$ & & & & & $0.217 * *$ & & & & & & $0.152^{* * *}$ & & & $-0.290^{* * *}$ & & & & \\
\hline$\Delta \mathrm{EX}(\mathrm{t}-3)$ & & & & & & & & $0.300^{* * * *}$ & & $-0.191 * *$ & & & & & & & & \\
\hline$\Delta \operatorname{EX}(\mathrm{t}-4)$ & $0.206^{* * *}$ & & $0.219 *$ & & & & & $0.288 * * *$ & & & & & & & & & & \\
\hline$\Delta \mathrm{FD}(\mathrm{t})$ & $1.258^{* * * *}$ & $0.682^{* * * *}$ & & $1.402^{* * *}$ & $0.844^{* * * *}$ & $1.237 * * *$ & $1.132 * * *$ & $1.309^{* * * *}$ & $1.011^{* * *}$ & & $1.170^{* * * *}$ & & 1. $116^{* * *}$ & $1.752^{* * *}$ & $0.698^{* * *}$ & $1.135^{* * * *}$ & $1.239 * * *$ & $1.293^{* * *}$ \\
\hline$\Delta \mathrm{FD}(\mathrm{t}-1)$ & & & & & & $-0.454^{* * *}$ & & & & & & & & & & & & \\
\hline$\Delta \mathrm{FD}(\mathrm{t}-2)$ & $-0.429^{* *}$ & & & & & & & & & & & & & & & & & \\
\hline$\Delta \mathrm{FD}(\mathrm{t}-3)$ & & & & & & & & $-0.592 * * *$ & & & & & $-0.557^{* * * *}$ & & & & & \\
\hline$\Delta \mathrm{FD}(\mathrm{t}-4)$ & & & & & & & & & & & & & & & & & & \\
\hline$\Delta \mathrm{HCI}(\mathrm{t})$ & & $-0.959 * *$ & & & & & & & $-0.687 * *$ & & & & & & & & & \\
\hline$\Delta \mathrm{HCI}(\mathrm{t}-1)$ & & & & & & & & $-1.441^{*}$ & & & & & & & & & & \\
\hline$\Delta \operatorname{HCI}(\mathrm{t}-2)$ & & & & & & & & & & & & & & & & & & \\
\hline$\Delta \operatorname{HCI}(\mathrm{t}-3)$ & & & & & & & & & & & & & & & & & & \\
\hline$\Delta \mathrm{HCI}(\mathrm{t}-4)$ & & & & & & & & & & & & $-0.748^{*}$ & & & & & & \\
\hline $\operatorname{ECM}(t-1)$ & $\mathrm{x}$ & $-0.473 * * *$ & $x$ & $-0.531^{* * * *}$ & $-0.274 * * *$ & $x$ & $-0.488^{* * * *}$ & $x$ & $-0.664 * * *$ & $x$ & $\mathrm{x}$ & $\mathrm{x}$ & $-0.264 * *$ & $x$ & $-0.588^{* * * *}$ & $-0.373^{* * *}$ & $-0.608^{* * * *}$ & $x$ \\
\hline \begin{tabular}{|l|}
$\mathrm{Adj} \mathrm{R} 2$ \\
\end{tabular} & 0.451 & 0.548 & 0.366 & 0.727 & 0.582 & 0.415 & 0.411 & 0.730 & 0.706 & 0.379 & 0.720 & 0.487 & 0.539 & 0.174 & 0.680 & 0.571 & 0.733 & 0.441 \\
\hline $\mathrm{JB}$ & 0.990 & 2.254 & 1.153 & 2.612 & 0.833 & 0.831 & 1.097 & 1.155 & 0.298 & 0.728 & 1.397 & 1.949 & 2.051 & 0.988 & 1.831 & 0.922 & 0.601 & 0.837 \\
\hline Wald(FD) & $\mathrm{x}$ & $-2.240 * *$ & $\mathrm{x}$ & 1.405 & $-2.884 * * *$ & $\mathrm{x}$ & $2.653^{* * * *}$ & $\mathrm{x}$ & 1.484 & $\mathrm{x}$ & $\mathrm{x}$ & $\mathrm{x}$ & 0.145 & $\mathrm{x}$ & $-2.148^{* * *}$ & -0.678 & $22.808^{* * * *}$ & $\mathrm{x}$ \\
\hline LM (4) & 1.045 & 0.006 & 1.678 & 1.371 & 0.675 & 0.483 & 0.014 & 1.092 & 1.308 & 0.229 & 0.133 & 0.390 & 0.237 & 0.493 & 0.091 & 0.840 & 1.922 & 0.573 \\
\hline
\end{tabular}

Notes: ***, ** and * imply significance levels at $1 \%, 5 \%$ and $10 \%$ respectively. $\mathrm{x}$ denotes the absence of value.

Table A8

Extra-euro area export estimation results using GDP-deflated HCI

\begin{tabular}{|c|c|c|c|c|c|c|c|c|c|c|c|c|c|c|c|c|c|c|}
\hline & AT & $\mathrm{BE}$ & $\mathrm{CY}$ & $\mathrm{DE}$ & $\mathrm{EE}$ & ES & FI & FR & GR & IE & IT & $\mathrm{LU}$ & LV & MT & $\mathrm{NL}$ & PT & SI & SK \\
\hline Const & $6.244^{* * * *}$ & $5.739 * * *$ & $7.076 * * *$ & $4.994 * * *$ & $7.229 * * *$ & $5.594 * * * *$ & $4.927 * * *$ & $7.102 * * *$ & $6.875^{* * * *}$ & $8.361 * * *$ & $6.107 * * *$ & $\mathrm{x}$ & $7.127 * * *$ & $3.896 * * *$ & $4.261 * * *$ & $4.773 * * *$ & $4.933^{* * * *}$ & $3.238 * * *$ \\
\hline FD & $0.966^{* * *}$ & $0.780^{* * * *}$ & $1.367^{* * * * *}$ & $1.101^{* * * *}$ & $1.331 * * *$ & $0.897 * * *$ & $1.110^{* * * *}$ & $0.630^{* * * *}$ & $0.351^{* * * *}$ & $\mathrm{x}$ & $0.924^{* * * *}$ & $\mathrm{x}$ & $1.289^{* * * *}$ & $1.531 * * *$ & $1.059^{* * * *}$ & $1.118^{* * * *}$ & $1.174^{* * * *}$ & $1.364^{* * * *}$ \\
\hline $\mathrm{HCl}$ & $-0.614 * * *$ & $-0.384 * * * *$ & $-0.760^{* * *}$ & $-0.285^{* * *}$ & $-018 * *$ & $-0.407^{* * * *}$ & $-0.290^{* * *}$ & $-0.700 * * * *$ & $-0.626^{* * * *}$ & $-1.146^{* * * *}$ & $-0.489 * * *$ & $\mathrm{x}$ & $-0.403^{* * *}$ & $x$ & $-0.176^{* * * *}$ & $-0.165^{* *}$ & $-0.394^{* * *}$ & $\mathrm{x}$ \\
\hline$\Delta \mathrm{EX}(\mathrm{t}-1)$ & & $-0.219^{* *}$ & $-0.276^{* * *}$ & & $-0.204 * *$ & & & & $-0.179 *$ & $0.244 * *$ & & & & & & $-0.180^{*}$ & & \\
\hline$\Delta \mathrm{EX}(\mathrm{t}-2)$ & & $-0.167^{* * *}$ & $0.154^{*}$ & & $0.149^{* *}$ & & & & & & & & & & & & & \\
\hline$\Delta \mathrm{EX}(\mathrm{t}-3)$ & $0.153 * *$ & & & & & & & & & & & & & & & & & \\
\hline$\Delta \mathrm{EX}(\mathrm{t}-4)$ & & & & & $0.147^{*}$ & $-0.261^{* * * *}$ & $0.333 * * *$ & $0.153 * *$ & & & & & & & & & & \\
\hline$\Delta \mathrm{FD}(\mathrm{t})$ & $1.206^{* * * *}$ & $1.557^{* * * *}$ & & $1.281^{* * *}$ & $1.567 * * *$ & $1.093 * * *$ & $1.100^{* * * *}$ & $0.964 * * *$ & $0.724 * *$ & & $1.143 * * *$ & 1. $111^{* * * *}$ & $0.972 * * *$ & $2.371 * * * *$ & $1.121 * * *$ & $1.157^{* * *}$ & $1.112^{* * *}$ & $0.905^{* * *}$ \\
\hline$\Delta \mathrm{FD}(\mathrm{t}-\mathrm{l})$ & & & & & & & & & $-0.599 *$ & & & & & & & & & \\
\hline$\Delta \mathrm{FD}(\mathrm{t}-2)$ & & & & $0.207^{*}$ & & & $0.494 * * *$ & & & & & & & & & & & \\
\hline$\Delta \mathrm{FD}(\mathrm{t}-3)$ & & & & & & & & & & & & & & & & & & \\
\hline$\Delta \mathrm{FD}(\mathrm{t}-4)$ & & & & & & $0.290^{*}$ & $-1.350^{* * * *}$ & & & & & $0.718^{*}$ & & & & & & \\
\hline$\Delta \mathrm{HCI}(\mathrm{t})$ & & & & & & & & $-0.479 * * *$ & & & & & & & & & & \\
\hline$\Delta \mathrm{HCI}(\mathrm{t}-1)$ & & & & & & & & & & & & & & & & & & \\
\hline$\Delta \mathrm{HCI}(\mathrm{t}-2)$ & & & & & $-0.837 * *$ & $-0.249^{*}$ & $-0.534 * * *$ & & & & & & & & $-0.236 * * *$ & & & \\
\hline$\Delta \mathrm{HCI}(\mathrm{t}-3)$ & & & & & & & & & & & & & & & & & & \\
\hline$\Delta \mathrm{HCI}(\mathrm{t}-4)$ & & & & & & & & & & & & & & & & & & \\
\hline $\operatorname{ECM}(t-1)$ & $-0.307 * * *$ & $-0.375^{* * * *}$ & $-0.307 * * *$ & $-0.590 * * *$ & $-0.410^{* * * *}$ & $-0.218^{* * *}$ & $-0.354 * * * *$ & $-0.487^{* * * *}$ & $-0.573 * * *$ & $-0.657^{* * * *}$ & $-0.466^{* * * *}$ & $\mathrm{x}$ & $-0.643 * * *$ & $-0.641^{* * * *}$ & $-0.751^{* * *}$ & $-0.453 * * *$ & $-0.426^{* * * *}$ & $-0.232^{* *}$ \\
\hline AdjR2 & 0.624 & 0.551 & 0.676 & 0.690 & 0.683 & 0.568 & 0.762 & 0.609 & 0.452 & 0.285 & 0.544 & 0.263 & 0.518 & 0.404 & 0.684 & 0.464 & 0.687 & 0.377 \\
\hline JB & 0.378 & 0.569 & 1.280 & 0.127 & 0.123 & 0.078 & 0.768 & 0.289 & 1.347 & 1.547 & 2. 174 & 0.936 & 0.206 & 2.321 & 1.526 & 1.854 & 1.588 & 0.213 \\
\hline Wald(FD) & -0.311 & -1.537 & $2.542^{* * *}$ & 1.366 & $1.853^{*}$ & -0.820 & 1.025 & $-3.508^{* * * *}$ & $-5.203^{* * *}$ & $\mathrm{x}$ & -0.740 & $\mathrm{x}$ & $3.013^{* * * *}$ & 1.315 & 1.216 & 0.829 & $2.488^{* * *}$ & $2.577^{* * *}$ \\
\hline LM (4) & 1.795 & 2.042 & 0.363 & 0.445 & 0.900 & 0.442 & 1.848 & 1.632 & 1.783 & 0.372 & 1.830 & 1.462 & 1.947 & 1.115 & 1.818 & 0.536 & 0.828 & 1.695 \\
\hline
\end{tabular}

Notes: $* * * * *$ and $*$ imply significance levels at $1 \%, 5 \%$ and $10 \%$ respectively. $\mathrm{x}$ denotes the absence of value. 
Table A9

Intra-euro area export estimation results using PPI-deflated HCI

\begin{tabular}{|c|c|c|c|c|c|c|c|c|c|c|c|c|c|c|c|c|c|c|}
\hline & AT & $\mathrm{BE}$ & $\mathrm{CY}$ & $\mathrm{DE}$ & $\mathrm{EE}$ & ES & FI & FR & GR & IE & IT & LU & LV & MT & $\mathrm{NL}$ & PT & SI & SK \\
\hline Const & $\mathrm{x}$ & $\mathrm{x}$ & $\mathrm{x}$ & $3.650^{* * *}$ & $4.065 * * * *$ & $\mathrm{x}$ & $3.836^{* * * *}$ & $\mathrm{x}$ & $3.752^{* * * *}$ & $\mathrm{x}$ & $\mathrm{x}$ & $\mathrm{x}$ & $4.513^{* * * *}$ & $\mathrm{x}$ & $7.840^{* * * *}$ & $3.888^{* * * *}$ & $3.319^{* * * *}$ & $\mathrm{x}$ \\
\hline FD & $x$ & $0.754^{* * * *}$ & $\mathrm{x}$ & $1.095 * * *$ & $0.401^{*}$ & $\mathrm{x}$ & $1.433^{* * * *}$ & $\mathrm{x}$ & $1.221 * * *$ & $\mathrm{x}$ & $\mathrm{x}$ & $\mathrm{x}$ & $1.016^{* * * *}$ & $\mathrm{x}$ & $1.063^{* * *}$ & $0.908^{* * * *}$ & $1.534 * * *$ & $\mathrm{x}$ \\
\hline $\mathrm{HCl}$ & $\mathrm{x}$ & $x$ & $x$ & $x$ & $x$ & $x$ & $x$ & $\mathrm{x}$ & $x$ & $\mathrm{x}$ & $\mathrm{x}$ & $\mathrm{x}$ & $\mathrm{x}$ & $x$ & $-0.917^{* *}$ & $x$ & $x$ & $\mathrm{x}$ \\
\hline$\Delta \mathrm{EX}(\mathrm{t}-1)$ & & & & & & & & $-0.425^{* * *} *$ & & $-0.254^{* * * *}$ & $-0.274 * * *$ & & & $-0.416 * * *$ & & & & \\
\hline$\Delta \mathrm{EX}(\mathrm{t}-2)$ & & & & & $0.217^{* *}$ & & & & & & $0.152^{* * *}$ & & & $-0.290 * *$ & & & & \\
\hline$\Delta \mathrm{EX}(\mathrm{t}-3)$ & & & & & & & & $0.363^{* * * *}$ & & $-0.191 * *$ & & & & & & & & \\
\hline$\Delta \operatorname{EX}(\mathrm{t}-4)$ & & & $0.219^{*}$ & & & & & $0.303^{* * * *}$ & & & & & & & & & & \\
\hline$\Delta \mathrm{FD}(\mathrm{t})$ & $0.924 * * *$ & $0.689^{* * * *}$ & & $1.402^{* * *}$ & $0.844^{* * * *}$ & $1.237 * * *$ & $1.132 * * *$ & $1.328 * * *$ & $1.004 * * *$ & & $1.170^{* * * *}$ & 1. $198^{* * * *}$ & 1. $116^{* * *}$ & $1.752^{* * *}$ & $0.864 * * *$ & $1.135^{* * * *}$ & $1.239 * * *$ & $1.284 * * *$ \\
\hline$\Delta \mathrm{FD}(\mathrm{t}-1)$ & & & & & & $-0.454^{* *}$ & & & & & & $-0.774^{*}$ & & & & & & \\
\hline$\Delta \mathrm{FD}(\mathrm{t}-2)$ & & & & & & & & & & & & & & & & & & \\
\hline$\Delta \mathrm{FD}(\mathrm{t}-3)$ & & & & & & & & $-0.730^{* * * *}$ & & & & & $-0.557^{* * * *}$ & & & & & \\
\hline$\Delta \mathrm{FD}(\mathrm{t}-4)$ & & & & & & & & & & & & & & & & & & \\
\hline$\Delta \mathrm{HCI}(\mathrm{t})$ & & & & & & & & & & & & & & & & & & \\
\hline$\Delta \mathrm{HCI}(\mathrm{t}-1)$ & & & & & & & & & & & & & & & & & & \\
\hline$\Delta \mathrm{HCI}(\mathrm{t}-2)$ & & & & & & & & & & & & & & & & & & \\
\hline$\Delta \operatorname{HCI}(\mathrm{t}-3)$ & & & & & & & & $-0.804^{*}$ & & & & & & & & & & $-0.461^{*}$ \\
\hline$\Delta \mathrm{HCI}(\mathrm{t}-4)$ & $-0.812^{*}$ & & & & & & & & & & & & & & & & & \\
\hline $\operatorname{ECM}(t-1)$ & $\mathrm{x}$ & $-0.348^{* * * *}$ & $\mathrm{x}$ & $-0.531^{* * *}$ & $-0.274 * * *$ & $x$ & $-0.488^{* * * *}$ & $x$ & $0.698^{* * * *}$ & $\mathrm{x}$ & $x$ & $\mathrm{x}$ & $-0.264 * *$ & $\mathrm{x}$ & $-0.329^{* *}$ & $-0.373^{* * * *}$ & $-0.608^{* * * *}$ & $x$ \\
\hline \begin{tabular}{|l|}
$\mathrm{Adj} \mathrm{R} 2$ \\
\end{tabular} & 0.436 & 0.509 & 0.366 & 0.727 & 0.582 & 0.415 & 0.411 & 0.732 & 0.629 & 0.379 & 0.720 & 0.580 & 0.539 & 0.174 & 0.347 & 0.571 & 0.733 & 0.465 \\
\hline $\mathrm{JB}$ & 2.397 & 2.674 & 1.153 & 2.612 & 0.833 & 0.831 & 1.097 & 1.309 & 0.890 & 0.728 & 1.397 & 2.063 & 2.051 & 0.988 & 4.103 & 0.922 & 0.601 & 1.309 \\
\hline Wald(FD) & $\mathrm{x}$ & $-2.527 *$ & $\mathrm{x}$ & 1.405 & $-2.884 * * *$ & $\mathrm{x}$ & $2.653^{* * * *}$ & $\mathrm{x}$ & 1. 136 & $\mathrm{x}$ & $\mathrm{x}$ & $\mathrm{x}$ & 0.145 & $\mathrm{x}$ & 0.330 & -0.678 & $22.808^{* * * *}$ & $\mathrm{x}$ \\
\hline LM (4) & 1.669 & 0.083 & 1.678 & 1.371 & 0.675 & 0.483 & 0.014 & 0.344 & 2.300 & 0.229 & 0.133 & 1.093 & 0.237 & 0.493 & 0.876 & 0.840 & 1.922 & 0.414 \\
\hline
\end{tabular}

Notes: ***, ** and * imply significance levels at $1 \%, 5 \%$ and $10 \%$ respectively. $\mathrm{x}$ denotes the absence of value.

Table A10

Extra-euro area export estimation results using PPI-deflated HCI

\begin{tabular}{|c|c|c|c|c|c|c|c|c|c|c|c|c|c|c|c|c|c|c|}
\hline & AT & $\mathrm{BE}$ & $\mathrm{CY}$ & $\mathrm{DE}$ & $\mathrm{EE}$ & ES & FI & FR & GR & IE & IT & $\mathrm{LU}$ & LV & MT & $\mathrm{NL}$ & PT & SI & SK \\
\hline Const & $6.696 * * *$ & $6.103^{* * * *}$ & $6.915^{* * * *}$ & $4.992 * * *$ & $10.560^{* * * *}$ & 6.081 **** & $5.566^{* * * *}$ & $7.334 * * *$ & $7.366^{* * * *}$ & $9.942 * * *$ & $6.490^{* * * *}$ & $\mathrm{x}$ & $7.359 * * *$ & $3.896 * * *$ & $4.440 * * *$ & $4.813 * * *$ & $4.824 * * *$ & $3.238 * * *$ \\
\hline FD & $0.948^{* * * *}$ & $0.944^{* * * *}$ & $1.422^{* * * *}$ & $1.099^{* * *}$ & $1.160^{* * * *}$ & $0.911^{* * * *}$ & $1.220^{* * * *}$ & $0.700^{* * * *}$ & $0.726^{* * * *}$ & $\mathrm{x}$ & $1.037^{* * * *}$ & $\mathrm{x}$ & $1.250^{* * * *}$ & $1.531^{* * * *}$ & 1. $143^{* * * *}$ & $1.155^{* * * *}$ & $1.147 * * *$ & $1.364 * * *$ \\
\hline $\mathrm{HCl}$ & $-0.711^{* * *}$ & $-0.479 * * *$ & $-0.731^{* * *}$ & $-0.288 * * *$ & $-1.808^{* * * *}$ & $-0.505^{* * * *}$ & $-0.430^{* * * *}$ & -0.750 **** & $-0.764^{* * * *}$ & $-1.448 * * *$ & $-0.578 * * *$ & $\mathrm{x}$ & $-0.460^{* * *}$ & $x$ & $-0.218^{* * * *}$ & $-0.176^{*}$ & $-0.364^{* *}$ & $x$ \\
\hline$\Delta \mathrm{EX}(\mathrm{t}-1)$ & & & $-0.275^{* * *}$ & & & & & & $-0.226^{* * *}$ & & $-0.276^{* * * *}$ & & & & & & & \\
\hline$\Delta \mathrm{EX}(\mathrm{t}-2)$ & & & $0.153^{*}$ & & $0.310^{* * * *}$ & & & & & & & & & & & & & \\
\hline$\Delta \mathrm{EX}(\mathrm{t}-3)$ & $0.151^{* * *}$ & & & & & & & & & & & & & & & & & \\
\hline$\Delta \mathrm{EX}(\mathrm{t}-4)$ & & & & & & $-0.268^{* * * *}$ & $0.319^{* * *}$ & 0.141 * & & & & & & & & & & \\
\hline$\Delta \mathrm{FD}(\mathrm{t})$ & $1.205^{* * * *}$ & $1.597 * * * *$ & & $1.297^{* * *}$ & $1.174 * * *$ & $1.091 * * *$ & $1.083^{* * * *}$ & $0.997 * * *$ & $1.048^{* * * *}$ & & $1.256^{* * * *}$ & 1. $111 * * *$ & $0.993 * * *$ & 2. $371^{* * * *}$ & $1.140^{* * * *}$ & $0.985^{* * * *}$ & $1.075^{* * * *}$ & $0.905 * * *$ \\
\hline$\Delta \mathrm{FD}(\mathrm{t}-\mathrm{l})$ & & $-0.426^{*}$ & & & & & & & $-0.710^{*}$ & & & & & & & & & \\
\hline$\Delta \mathrm{FD}(\mathrm{t}-2)$ & & & & & $-0.579^{* * *}$ & & $0.606^{* * *}$ & & & & $0.318^{*}$ & & & & & & & \\
\hline$\Delta \mathrm{FD}(\mathrm{t}-3)$ & & & & & & $0.309^{*}$ & & & & & & & & & & & & \\
\hline$\Delta \mathrm{FD}(\mathrm{t}-4)$ & & & & & $0.390^{* * * *}$ & & $-1.325^{* * * *}$ & & & & & $0.718^{*}$ & & & & & & \\
\hline$\Delta \mathrm{HCI}(\mathrm{t})$ & & & & & $-1.065^{* * * *}$ & & & $-0.444 * * *$ & $-0.706^{* * * *}$ & $-0.389 *$ & & & & & & & & \\
\hline$\Delta \mathrm{HCI}(\mathrm{t}-1)$ & & & & & & & & & & & & & & & & & & \\
\hline$\Delta \mathrm{HCI}(\mathrm{t}-2)$ & & & & & $-1.015^{* * *}$ & $-0.252^{*}$ & $-0.419^{*}$ & & $-0.393^{*}$ & & & & & & $-0.253^{* * *}$ & & & \\
\hline$\Delta \mathrm{HCI}(\mathrm{t}-3)$ & & & & & & & & & & & & & & & & & & \\
\hline$\Delta \mathrm{HCI}(\mathrm{t}-4)$ & & & & & & & & & & & $-0.222^{*}$ & & & & & & & \\
\hline $\operatorname{ECM}(t-1)$ & $-0.283 * * *$ & $-0.484 * * * *$ & $-0.316^{* * * *}$ & $-0.548 * * *$ & $-0.568^{* * * *}$ & $-0.207 * *$ & $-0.393^{* * * *}$ & $-0.435^{* * * *}$ & $-0.525^{* * * *}$ & $-0.507 * * *$ & $-0.259 * *$ & $\mathrm{x}$ & $-0.626^{* * * *}$ & $-0.641^{* * * *}$ & $-0.831 * * *$ & $-0.579 * * *$ & $-0.367^{* * *}$ & $-0.232^{* *}$ \\
\hline AdjR2 & 0.612 & 0.518 & 0.681 & 0.680 & 0.632 & 0.560 & 0.746 & 0.593 & 0.455 & 0.241 & 0.524 & 0.263 & 0.515 & 0.404 & 0.678 & 0.471 & 0.672 & 0.377 \\
\hline JB & 0.364 & 1.052 & 0.081 & 0.471 & 0.283 & 0.061 & 1. 143 & 0.300 & 0.914 & 0.071 & 2.569 & 0.936 & 0.185 & 2.321 & 3.030 & 0.898 & 1.258 & 0.213 \\
\hline Wald(FD) & -0.490 & -0.426 & $2.746^{* * * *}$ & 1.332 & 0.943 & -0.638 & $2.002^{* *}$ & $-2.602^{* * *}$ & $-1.733^{*}$ & $\mathrm{x}$ & 0.360 & $\mathrm{x}$ & $2.567^{* * *}$ & 1.315 & $2.586^{* * *}$ & 1.043 & $1.961^{*}$ & $2.577^{* * *}$ \\
\hline LM (4) & 1.761 & $3.070^{* *}$ & 0.453 & 0.046 & 1.885 & 0.389 & 1.787 & 1.624 & 0.959 & 1.396 & 0.577 & 1.462 & $2.098^{*}$ & 1.115 & 0.603 & 1.641 & 0.832 & 1.695 \\
\hline
\end{tabular}

Notes: $* * *, * *$ and $*$ imply significance levels at $1 \%, 5 \%$ and $10 \%$ respectively. $\mathrm{x}$ denotes the absence of value. 
Table A11

Intra-euro area export estimation results using ULCM-deflated HCI

\begin{tabular}{|c|c|c|c|c|c|c|c|c|c|c|c|c|c|c|c|c|c|c|}
\hline & AT & $\mathrm{BE}$ & $\mathrm{CY}$ & $\mathrm{DE}$ & $\mathrm{EE}$ & ES & FI & FR & GR & IE & IT & LU & LV & MT & $\mathrm{NL}$ & PT & SI & SK \\
\hline Const & $\mathrm{x}$ & $\mathrm{x}$ & $\mathrm{x}$ & $3.650^{* * *}$ & $6.573^{* * * *}$ & $7.280^{* * * *}$ & $3.836^{* * * *}$ & $\mathrm{x}$ & $3.752^{* * * *}$ & $7.329 * * *$ & $\mathrm{x}$ & $\mathrm{x}$ & $4.513^{* * * *}$ & $\mathrm{x}$ & $8.084^{* * * *}$ & $3.888^{* * * *}$ & $3.319 * * *$ & $x$ \\
\hline FD & $\mathrm{x}$ & $0.754^{* * * *}$ & $x$ & $1.095^{* * *}$ & $1.054 * * *$ & $0.919^{* * * *}$ & $1.433 * * *$ & $\mathrm{x}$ & $1.221 * * *$ & $1.008^{* * * *}$ & $\mathrm{x}$ & $\mathrm{x}$ & $1.016^{* * * *}$ & $x$ & $0.717^{* * * *}$ & $0.908^{* * * *}$ & $1.534^{* * * *}$ & $\mathrm{x}$ \\
\hline $\mathrm{HCl}$ & $\mathrm{x}$ & $x$ & $x$ & $x$ & $-0.629 * * *$ & $-0.799^{* * *}$ & $\mathrm{x}$ & $\mathrm{x}$ & $\mathrm{x}$ & $-0.830^{* * * *}$ & $\mathrm{x}$ & $\mathrm{x}$ & $\mathrm{x}$ & $\mathrm{x}$ & $-0.937 * * *$ & $x$ & $x$ & $x$ \\
\hline$\Delta \mathrm{EX}(\mathrm{t}-1)$ & & & & & & & & $-0.407 * * *$ & & & $-0.274^{* * *}$ & & & $-0.416^{* * *}$ & & & & \\
\hline$\Delta \mathrm{EX}(\mathrm{t}-2)$ & & & & & $0.242 * *$ & & & & & & $0.152^{* * *}$ & & & $-0.290^{* * *}$ & & & & \\
\hline$\Delta \mathrm{EX}(\mathrm{t}-3)$ & & & & & & & & $0.315^{* * * *}$ & & & & & & & & & & \\
\hline$\Delta \operatorname{EX}(\mathrm{t}-4)$ & $0.246 * *$ & & $0.219^{*}$ & & & & & $0.297 * * *$ & & & & & & & & & & \\
\hline$\Delta \mathrm{FD}(\mathrm{t})$ & $1.348^{* * * *}$ & $0.730^{* * * *}$ & & $1.402^{* * *}$ & $0.730^{* *}$ & $0.963^{* * *}$ & $0.910^{* * * *}$ & $1.326^{* * * *}$ & $1.004 * * *$ & & $1.170^{* * * *}$ & $0.885^{* * *}$ & 1. $116^{* * * *}$ & $1.752^{* * *}$ & $0.938^{* * *}$ & $1.135^{* * * *}$ & $1.239 * * *$ & $1.293^{* * *}$ \\
\hline$\Delta \mathrm{FD}(\mathrm{t}-1)$ & & & & & & & & & & & & & & & & & & \\
\hline$\Delta \mathrm{FD}(\mathrm{t}-2)$ & $-0.493 * * *$ & & & & & & & & & & & $-1.428^{* * * *}$ & & & & & & \\
\hline$\Delta \mathrm{FD}(\mathrm{t}-3)$ & & & & & & & & $-0.659 * * *$ & & & & $0.912^{* *}$ & $-0.557^{* * * *}$ & & & & & \\
\hline$\Delta \mathrm{FD}(\mathrm{t}-4)$ & & & & & & & & & & & & & & & & & & \\
\hline$\Delta \mathrm{HCI}(\mathrm{t})$ & & & & & & & $-0.481^{* *}$ & & & $-0.366^{* * * *}$ & & & & & & & & \\
\hline$\Delta \operatorname{HCI}(\mathrm{t}-1)$ & $-0.542 * *$ & & & & & & & & & & & & & & & & & \\
\hline$\Delta \mathrm{HCI}(\mathrm{t}-2)$ & & & & & & & & & & & & & & & & & & \\
\hline$\Delta \operatorname{HCI}(\mathrm{t}-3)$ & & $-0.333^{* * * *}$ & & & & $-0.428^{* *}$ & & & & & & $-0.386^{* * *}$ & & & & & & \\
\hline$\Delta \mathrm{HCI}(\mathrm{t}-4)$ & & & & & & & & & & & & & & & & & & \\
\hline $\operatorname{ECM}(t-1)$ & $\mathrm{x}$ & $-0.363^{* * * *}$ & $\mathrm{x}$ & $-0.531^{* * *}$ & $-0.492^{* * *}$ & $-0.195^{* * *}$ & $-0.489 * * *$ & $=x$ & $0.698^{* * * *}$ & $-0.693^{* * *}$ & $\mathrm{x}$ & $x$ & $-0.264^{* *}$ & $x$ & $-0.373^{* * *}$ & $-0.373^{* * *}$ & $-0.608^{* * * *}$ & $x$ \\
\hline \begin{tabular}{|l|}
$\mathrm{Adj} \mathrm{R} 2$ \\
\end{tabular} & 0.495 & 0.540 & 0.366 & 0.727 & 0.476 & 0.489 & 0.447 & 0.722 & 0.629 & 0.555 & 0.720 & 0.648 & 0.539 & 0.174 & 0.557 & 0.571 & 0.733 & 0.441 \\
\hline $\mathrm{JB}$ & 1.561 & 2.085 & 1.153 & 2.612 & 0.049 & 1.044 & 1.032 & 1.856 & 0.890 & 0.976 & 1.397 & 2.961 & 2.051 & 0.988 & 1.522 & 0.922 & 0.601 & 0.837 \\
\hline Wald(FD) & $\mathrm{x}$ & $-2.527 *$ & $\mathrm{x}$ & 1.405 & 0.266 & -0.476 & $2.653^{* * * *}$ & $\mathrm{x}$ & 1. 136 & 0.043 & $\mathrm{x}$ & $\mathrm{x}$ & 0.145 & $\mathrm{x}$ & $-2.243^{* *}$ & -0.678 & $22.808^{* * * *}$ & $\mathrm{x}$ \\
\hline LM (4) & 0.867 & 0.115 & 1.678 & 1.371 & 0.09 & 0.609 & 0.078 & 0.725 & 2.300 & 0.469 & 0.133 & 1.015 & 0.237 & 0.493 & 0.926 & 0.840 & 1.922 & 0.573 \\
\hline
\end{tabular}

Notes: ***, ** and * imply significance levels at $1 \%, 5 \%$ and $10 \%$ respectively. $\mathrm{x}$ denotes the absence of value.

Table A12

\section{Extra-euro area export estimation results using ULCM-deflated HCI}

\begin{tabular}{|c|c|c|c|c|c|c|c|c|c|c|c|c|c|c|c|c|c|c|}
\hline & AT & $\mathrm{BE}$ & $\mathrm{CY}$ & $\mathrm{DE}$ & $\mathrm{EE}$ & ES & FI & FR & GR & IE & IT & $\mathrm{LU}$ & LV & MT & $\mathrm{NL}$ & PT & SI & SK \\
\hline Const & $5.482^{* * * *}$ & $5.573^{* * * *}$ & $6.050 * * *$ & $4.963^{* * *}$ & $4.558^{* * * *}$ & $5.313 * * *$ & $4.791 * * *$ & $6.657 * * *$ & $6.112^{* * * *}$ & $5.834^{* * * *}$ & $5.639 * * *$ & $\mathrm{x}$ & $6.241^{* * * *}$ & $3.896^{* * * *}$ & $4.061^{* * * *}$ & $4.732^{* * * *}$ & $4.205^{* * * *}$ & $3.238 * * *$ \\
\hline FD & $0.806^{* * * *}$ & $0.825^{* * * *}$ & $1.503^{* * * *}$ & $0.942^{* * * *}$ & $1.277 * * *$ & $0.990^{* * *}$ & $1.030^{* * * *}$ & $0.640^{* * * *}$ & $0.745^{* * *}$ & $0.436^{* *}$ & $0.927 * * * *$ & $\mathrm{x}$ & $1.412^{2 * * *}$ & $1.531^{* * * *}$ & $1.018^{* * * *}$ & $1.115^{* * * *}$ & $1.170^{* * * *}$ & $1.364 * * *$ \\
\hline $\mathrm{HCl}$ & $-0.452^{* * * *}$ & $-0.355^{* * * *}$ & $-0.525 * *$ & $-0.270 * * *$ & $-0.411 *$ & $-0.354^{* * * *}$ & $-0.248 * *$ & $-0.600 * * * *$ & $-0.492^{* * * *}$ & $-0.553^{* * * *}$ & $-0.391 * * *$ & $\mathrm{x}$ & $-0.179^{* * *}$ & $\mathrm{x}$ & $-0.129^{* * * *}$ & $-0.157^{* *}$ & $-0.223^{*}$ & $x$ \\
\hline$\Delta \operatorname{EX}(\mathrm{t}-1)$ & & & $-0.308^{* * *}$ & & & & & & $-0.213^{* *}$ & $0.185^{*}$ & & & & & & & & \\
\hline$\Delta \mathrm{EX}(\mathrm{t}-2)$ & $0.244 * * *$ & $-0138^{*}$ & $0.194 * *$ & & $0.195 * *$ & & & & & & $0.139^{*}$ & & & & & & & \\
\hline$\Delta \mathrm{EX}(\mathrm{t}-3)$ & $0.189 * *$ & & & & & & $-0.153^{* * *}$ & & & $0.197^{* * *}$ & & & & & & & & \\
\hline$\Delta \mathrm{EX}(\mathrm{t}-4)$ & & & & & & $-0.251^{* *}$ & $0.271^{* * *}$ & $0.144 *$ & & $0.176^{*}$ & & & & & & & & \\
\hline$\Delta \mathrm{FD}(\mathrm{t})$ & $1.160^{* * * *}$ & $1.417^{* * * *}$ & & $1.253^{* * *}$ & $1.344^{* * * *}$ & 1. $103^{* * *}$ & $1.081^{* * * *}$ & $0.972 * * *$ & $1.013^{* * *}$ & & $1.069^{* * *}$ & 1. $111^{* * * *}$ & $0.991^{* * * *}$ & $2.371^{* * * *}$ & $1.074 * * *$ & $1.014 * * *$ & $1.076^{* * * *}$ & $0.905^{* * *}$ \\
\hline$\Delta \mathrm{FD}(\mathrm{t}-1)$ & & & & & & & & & & & & & & & & & & \\
\hline$\Delta \mathrm{FD}(\mathrm{t}-2)$ & $-0.376^{* *}$ & & & $0.203^{*}$ & & & $0.701 * * *$ & & & & & & & & & & & \\
\hline$\Delta \mathrm{FD}(\mathrm{t}-3)$ & & & & & & $0.307^{* * * *}$ & & & & & & & & & & & & \\
\hline$\Delta \mathrm{FD}(\mathrm{t}-4)$ & & $-0.278 *$ & & & & & $-1.093^{* * * *}$ & & & & & $0.718^{*}$ & & & & & & \\
\hline$\Delta \mathrm{HCI}(\mathrm{t})$ & & & $-0.631^{* *}$ & & & & & $-0.472^{* * * *}$ & & $-0.280^{* * * *}$ & $-0.164^{*}$ & & & & & & & \\
\hline$\Delta \mathrm{HCI}(\mathrm{t}-1)$ & & & & & & & & & $-0.290^{* *}$ & & & & & & $-0.161^{* *}$ & & & \\
\hline$\Delta \mathrm{HCI}(\mathrm{t}-2)$ & & & & & & & & & $-0.379^{* * * *}$ & & & & & & $-0.155^{* * *}$ & & & \\
\hline$\Delta \mathrm{HCI}(\mathrm{t}-3)$ & & & & & & & & & & & & & & & & & & \\
\hline$\Delta \mathrm{HCI}(\mathrm{t}-4)$ & & & & & & & & & & & & & & & & & & \\
\hline $\operatorname{ECM}(t-1)$ & $-0.287^{* * *}$ & $-0.470^{* * * *}$ & $-0.268^{* * *}$ & $-0.728^{* * * *}$ & $-0.379^{* * * *}$ & $-0.359^{* * * *}$ & $-0.389 * * *$ & $-0.514^{* * *}$ & $-0.540^{* * * *}$ & $-0612 * * *$ & $-0.578^{* * * *}$ & $\mathrm{x}$ & $-0.616^{* * * *}$ & -0.641 **** & $-0.674 * * *$ & $-0.564 * * *$ & $-0.268^{* *}$ & $-0.232 * *$ \\
\hline AdjR2 & 0.668 & 0.547 & 0.696 & 0.720 & 0.613 & 0.563 & 0.776 & 0.612 & 0.484 & 0.346 & 0.5992 & 0.263 & 0.511 & 0.404 & 0.674 & 0.462 & 0.651 & 0.377 \\
\hline JB & 1.771 & 1.045 & 0.470 & 0.798 & 1.589 & 0.463 & 0.527 & 2.816 & 1.414 & 2.219 & 2.093 & 0.936 & 0.171 & 2.321 & 3.286 & 0.577 & 1.217 & 0.213 \\
\hline Wald (FD) & $-1.954^{*}$ & -1.248 & $2.986 * * *$ & -0.968 & 1.426 & -0.089 & 0.248 & $-3.625^{* * *}$ & $-1.734 *$ & $-3.111^{* * *}$ & -0.819 & $\mathrm{x}$ & $3.492^{* * * *}$ & 1.315 & 0.362 & 0.766 & $2.046^{* * *}$ & $2.577^{* * *}$ \\
\hline LM (4) & 1.484 & 0.981 & 0.953 & 0.45 & 1.194 & 0.101 & 1.261 & 1.038 & 1.208 & 0.423 & 1.279 & 1.462 & 1.548 & 1.115 & 1.625 & 2.272 & 0.896 & 1.695 \\
\hline
\end{tabular}

Notes: $* * * * *$ and $*$ imply significance levels at $1 \%, 5 \%$ and $10 \%$ respectively. $\mathrm{x}$ denotes the absence of value. 
Table A13

Intra-euro area export estimation results using ULCT-deflated HCI

\begin{tabular}{|c|c|c|c|c|c|c|c|c|c|c|c|c|c|c|c|c|c|c|}
\hline & AT & $\mathrm{BE}$ & $\mathrm{CY}$ & $\mathrm{DE}$ & $\mathrm{EE}$ & ES & FI & FR & GR & $\mathrm{IE}$ & IT & $\mathrm{LU}$ & LV & MT & $\mathrm{NL}$ & PT & SI & SK \\
\hline Const & $x$ & $x$ & $x$ & $3.650^{* * * *}$ & $8.036^{* * * *}$ & $8.858^{* * * *}$ & $3.836^{* * *}$ & $\mathrm{x}$ & $5.703^{* * * *}$ & $9.897 * * *$ & $7.728 * * *$ & $\mathrm{x}$ & $4.513^{* * * *}$ & $x$ & $10.688^{* * * *}$ & $3.888^{* * * *}$ & $3.319^{* * * *}$ & $\mathrm{x}$ \\
\hline FD & $x$ & $0.754 * * *$ & $\mathrm{x}$ & $1.095 * * *$ & $1.055^{* * * *}$ & $0.767^{* * * *}$ & $1.433^{* * * *}$ & $\mathrm{x}$ & $1.046^{* * * *}$ & $0.496^{* * *}$ & $1.254^{* * * *}$ & $\mathrm{x}$ & $1.016^{* * * *}$ & $\mathrm{x}$ & $0.638^{* * * *}$ & $0.908^{* * * *}$ & $1.534^{* * * *}$ & $\mathrm{x}$ \\
\hline $\mathrm{HCI}$ & $\mathrm{x}$ & $x$ & $x$ & $x$ & $-0.974 * * *$ & $-1.134 * * *$ & $\mathrm{x}$ & $\mathrm{x}$ & $-0.421^{* * *}$ & $-1.387 * * *$ & $-0.869^{* * *}$ & $\mathrm{x}$ & $\mathrm{x}$ & $x$ & $-1.501^{* * * *}$ & $\mathrm{x}$ & $\mathrm{x}$ & $x$ \\
\hline$\Delta \mathrm{EX}(\mathrm{t}-1)$ & & & & & & & & $-0.407 * * *$ & $-0.194^{* * *}$ & & $-0.278 * * * *$ & & & $-0.416^{* * * *}$ & $0.140^{* * *}$ & & & \\
\hline$\Delta \mathrm{EX}(\mathrm{t}-2)$ & & & & & $0.190^{* * *}$ & & & & $-0.158^{* * *}$ & & & & & $-0.290 * *$ & & & & \\
\hline$\Delta \mathrm{EX}(\mathrm{t}-3)$ & & & & & & & & $0.315^{\text {**** }}$ & & & & & & & & & & \\
\hline$\Delta \mathrm{EX}(\mathrm{t}-4)$ & $0.206^{* * *}$ & & $0.219^{*}$ & & & & & $0.297 * * *$ & & $0.166^{*}$ & & & & & & & & \\
\hline$\Delta \mathrm{FD}(\mathrm{t})$ & $1.258^{* * * *}$ & $0.754^{* * *}$ & & $1.402^{* * * *}$ & $0.816^{* * * *}$ & $1.097 * * * *$ & $1.132^{* * * *}$ & $1.326^{* * * *}$ & $1.032^{* * * *}$ & & $1.267 * * *$ & $1.198 * * *$ & 1. $116^{* * * *}$ & $1.752^{* *}$ & $0.893^{* * * *}$ & $1.135^{* * * *}$ & $1.239 * * *$ & $1.293^{* * * *}$ \\
\hline$\Delta \mathrm{FD}(\mathrm{t}-1)$ & & & & & & $-0.422^{* * *}$ & & & & & & $-0.774^{*}$ & & & & & & \\
\hline$\Delta \mathrm{FD}(\mathrm{t}-2)$ & $-0.429 * *$ & $-0.195^{*}$ & & & & & & & & & & & & & & & & \\
\hline$\Delta \mathrm{FD}(\mathrm{t}-3)$ & & & & & & & & $-0.659 * * *$ & & & & & $-0.557 * * *$ & & & & & \\
\hline$\Delta \mathrm{FD}(\mathrm{t}-4)$ & & & & & & & & & & & & & & & & & & \\
\hline$\Delta \mathrm{HCI}(\mathrm{t})$ & & & & & $-1.321 * * *$ & & & & & $-0.630^{* *}$ & & & & & & & & \\
\hline$\Delta \mathrm{HCI}(\mathrm{t}-1)$ & & & & & & & & & & & & & & & & & & \\
\hline$\Delta \mathrm{HCl}(\mathrm{t}-2)$ & & & & & & & & & & & $-0.303^{*}$ & & & & & & & \\
\hline$\Delta \mathrm{HCI}(\mathrm{t}-3)$ & & $-0.498^{*}$ & & & & & & & & & & & & & & & & \\
\hline$\Delta \mathrm{HCl}(\mathrm{t}-4)$ & & & & & & & & & & & & & & & & & & \\
\hline $\operatorname{ECM}(t-1)$ & $x$ & $-0.350^{* * * *}$ & $\mathrm{x}$ & $-0.531^{* * * *}$ & $-0.565^{* * * *}$ & $-0.261^{* * *}$ & $-0.488^{* * * *}$ & $\mathrm{x}$ & $-0.564 * * * *$ & $-0.496^{* * *}$ & $-0.496^{6 * * *}$ & $\mathrm{x}$ & $-0.264^{* * *}$ & $x$ & $-0.716^{* * * *}$ & $-0.373^{* * * *}$ & $-0.608^{* * * *}$ & $\mathrm{x}$ \\
\hline AdjR2 & 0.451 & 0.530 & 0.366 & 0.727 & 0.696 & 0.461 & 0.411 & 0.722 & 0.722 & 0.489 & 0.791 & 0.580 & 0.539 & 0.174 & 0.527 & 0.571 & 0.733 & 0.441 \\
\hline $\mathrm{JB}$ & 0.990 & 1.190 & 1.153 & 2.612 & 1.090 & 0.311 & 1.097 & 1.856 & 3.094 & 0.498 & 1.881 & 2.063 & 2.051 & 0.988 & 2.377 & 0.922 & 0.601 & 0.837 \\
\hline Wald $(F D)$ & $\mathrm{x}$ & $-2.527^{*}$ & $x$ & 1.405 & 0.303 & -1.561 & $2.653^{* * * *}$ & $\mathrm{x}$ & 0.264 & $-2.002 * *$ & $5.600^{* * * * *}$ & $\mathrm{x}$ & 0.145 & $\mathrm{x}$ & $-4.196 * * *$ & -0.678 & $22.808^{* * *}$ & $\mathrm{x}$ \\
\hline LM(4) & 1.045 & 0.006 & 1.678 & 1.371 & 0.493 & 1.246 & 0.014 & 0.725 & 1.735 & 0.320 & 0.471 & 1.093 & 0.237 & 0.493 & 0.588 & 0.840 & 1.922 & 0.573 \\
\hline
\end{tabular}

Notes: ***, ** and $*$ imply significance levels at $1 \%, 5 \%$ and $10 \%$ respectively. $\mathrm{x}$ denotes the absence of value.

Table A14

Extra-euro area export estimation results using ULCT-deflated HCI

\begin{tabular}{|c|c|c|c|c|c|c|c|c|c|c|c|c|c|c|c|c|c|c|}
\hline & AT & $\mathrm{BE}$ & $\mathrm{CY}$ & DE & $\mathrm{EE}$ & ES & FI & FR & GR & $\mathrm{IE}$ & IT & $\mathrm{LU}$ & LV & MT & $\mathrm{NL}$ & $\begin{array}{l}\text { PT } \\
\end{array}$ & SI & SK \\
\hline Const & $6.124^{* * * *}$ & $5.766^{* * * *}$ & $6.552^{* * * *}$ & $5.053^{* * * *}$ & $5.492^{* * * *}$ & $5.627 * * * *$ & $4.850^{* * * *}$ & $6.870^{* * * *}$ & $6.035^{* * * *}$ & $6.732 * * *$ & $5.763^{* * * *}$ & $x$ & $6.251^{* * * *}$ & $3.896 * * *$ & 4. $196 * * *$ & $4.684 * * * *$ & $4.620^{* * * *}$ & $3.238^{* * * *}$ \\
\hline FD & $0.929^{* * * *}$ & $0.741^{* * * *}$ & $1.292 * * *$ & $1.059^{* * * *}$ & $1.379^{* * * *}$ & $0.923^{* * *}$ & 1. $110^{* * * *}$ & $0.629^{* * *}$ & $0.398^{* * * *}$ & $\mathrm{x}$ & $0.974 * * *$ & $\mathrm{x}$ & $1.361^{* * * *}$ & $1.531^{* * * *}$ & $1.032 * * *$ & $1.062^{* * * *}$ & $1.139^{* * * *}$ & $1.364^{* * * *}$ \\
\hline $\mathrm{HCI}$ & $-0.578 * * *$ & $-0.388^{* * * *}$ & $-0.636^{* *}$ & $-0.291 * * *$ & $-0.650^{* * * *}$ & $-0.412^{* * * *}$ & $-0.270^{* * *}$ & $-0.647 * * *$ & $-0.443^{* * * *}$ & $-0.747 * * *$ & $-0.408^{* * * *}$ & $\mathrm{x}$ & $-0.208 * * *$ & $x$ & $-0.157 * * *$ & $-0.141 *$ & $-0.325^{* *}$ & $\mathrm{x}$ \\
\hline$\Delta \mathrm{EX}(\mathrm{t}-1)$ & & & $-0.298 * * *$ & & & & & & $-0.196 * *$ & $0.329^{* * * *}$ & & & & & & & & \\
\hline$\Delta \mathrm{EX}(\mathrm{t}-2)$ & $0.244 * * *$ & $-0198^{* * *}$ & $0.191^{* * * *}$ & & $0.185 * *$ & & & & & & $0.149^{*}$ & & & & & & & \\
\hline$\Delta \mathrm{EX}(\mathrm{t}-3)$ & $0.186 * *$ & & & & & & $-0.162^{* * *}$ & & & $0.238 * *$ & & & & & & & & \\
\hline$\Delta \mathrm{EX}(\mathrm{t}-4)$ & & & & & & $-0.251^{* * * *}$ & $0.261 * * *$ & $0.157^{* * *}$ & & & & & & & & & & \\
\hline$\Delta \mathrm{FD}(\mathrm{t})$ & $1.186^{* * * *}$ & $1.392^{* * * *}$ & & $1.279^{* * * *}$ & $1.326^{* * * *}$ & $1.094 * * * *$ & $1.097 * * *$ & $1.023^{* * *}$ & $0.855^{* *}$ & & 1. $104 * * * *$ & 1. 111 **** & $0.978^{* * * *}$ & $2.434^{* * *}$ & $1.129 * * *$ & $1.012 * * *$ & $1.068^{* * * *}$ & $0.905 * * *$ \\
\hline$\Delta \mathrm{FD}(\mathrm{t}-1)$ & & & & & & & & & $-0.707 * *$ & & & & & & & & & \\
\hline$\Delta \mathrm{FD}(\mathrm{t}-2)$ & $-0.377^{* * *}$ & & & $0.224^{*}$ & & & $0.586^{* * * *}$ & & & & & & & & & & & \\
\hline$\Delta \mathrm{FD}(\mathrm{t}-3)$ & & & & & & $0.314 *$ & & & & & & & & & & & & \\
\hline$\Delta \mathrm{FD}(\mathrm{t}-4)$ & & $-0.261 *$ & & & & & $-1.086^{* * *}$ & & & & & $0.718^{*}$ & & & & & & \\
\hline$\Delta \mathrm{HCl}(\mathrm{t})$ & & & $-0 . .957 * * *$ & & & & & $-0.511^{* * *}$ & $-0.598 * * *$ & & $-0.213^{* *}$ & & & & & & & \\
\hline$\Delta \mathrm{HCI}(\mathrm{t}-1)$ & & & & & & & & & & & & & & $-1.238^{* *}$ & $-0.125^{*}$ & & & \\
\hline$\Delta \mathrm{HCI}(\mathrm{t}-2)$ & & & & & & & $-0.301^{*}$ & & $-0.475^{* * *}$ & & & & & & $-0.200^{* * *}$ & & & \\
\hline$\Delta \mathrm{HCI}(\mathrm{t}-3)$ & & & & & & & & & & & & & & & & & & \\
\hline$\Delta \mathrm{HCI}(\mathrm{t}-4)$ & & & & & & & & & & & & & & & & & & \\
\hline $\operatorname{ECM}(t-1)$ & $-0.278^{* * * *}$ & $-0.417^{\text {*** }}$ & $-0.303^{* * * *}$ & $-0.590 * * * *$ & $-0.696^{* * *}$ & $-0.360^{* * * *}$ & $-0.364 * * * *$ & $-0.496 * * * *$ & $-0.645^{* * * *}$ & $-0.696^{* * * *}$ & $-0.505^{* * * *}$ & $\mathrm{x}$ & $-0.587 * * *$ & $-0.702^{* * * *}$ & $-0.713^{* * * *}$ & $-0.539^{* * * *}$ & $-0.317^{* * *}$ & $-0.232^{* * *}$ \\
\hline AdjR2 & 0.666 & 0.574 & 0.741 & 0.686 & 0.608 & 0.573 & 0.789 & 0.630 & 0.532 & 0.355 & 0.584 & 0.263 & 0.501 & 0.449 & 0.687 & 0.452 & 0.658 & 0.377 \\
\hline $\mathrm{JB}$ & 1.728 & 1.409 & 0.394 & 0.130 & 2. 177 & 0.647 & 0.410 & 0.754 & 1.217 & 2.906 & 1.342 & 0.936 & 0.366 & 0.733 & 1.368 & 0.461 & 1.196 & 0.213 \\
\hline Wald $(\mathrm{FD})$ & -0.703 & $-1.875^{*}$ & $2.534 * *$ & 0.771 & 2. $206 * *$ & -0.700 & 1.037 & $-3.662^{* * *}$ & $-5.360^{* * *}$ & $\mathrm{x}$ & -0.250 & $\mathrm{x}$ & $3.227 * * *$ & 1.315 & 0.668 & 0.410 & $1.719 *$ & $2.577^{* * *}$ \\
\hline $\operatorname{LM}(4)$ & 1.234 & 1.007 & 1.510 & 0.481 & 1.060 & 0.079 & 1. 164 & 2.062 & 1.422 & 0.031 & 1.386 & 1.462 & 1.591 & 0.790 & 1.461 & $2.643^{*}$ & 0.760 & 1.695 \\
\hline
\end{tabular}

Notes: $* * *, * *$ and $*$ imply significance levels at $1 \%, 5 \%$ and $10 \%$ respectively. $\mathrm{x}$ denotes the absence of value. 
Table A15

Intra-euro area import estimation results using CPI-deflated HCI

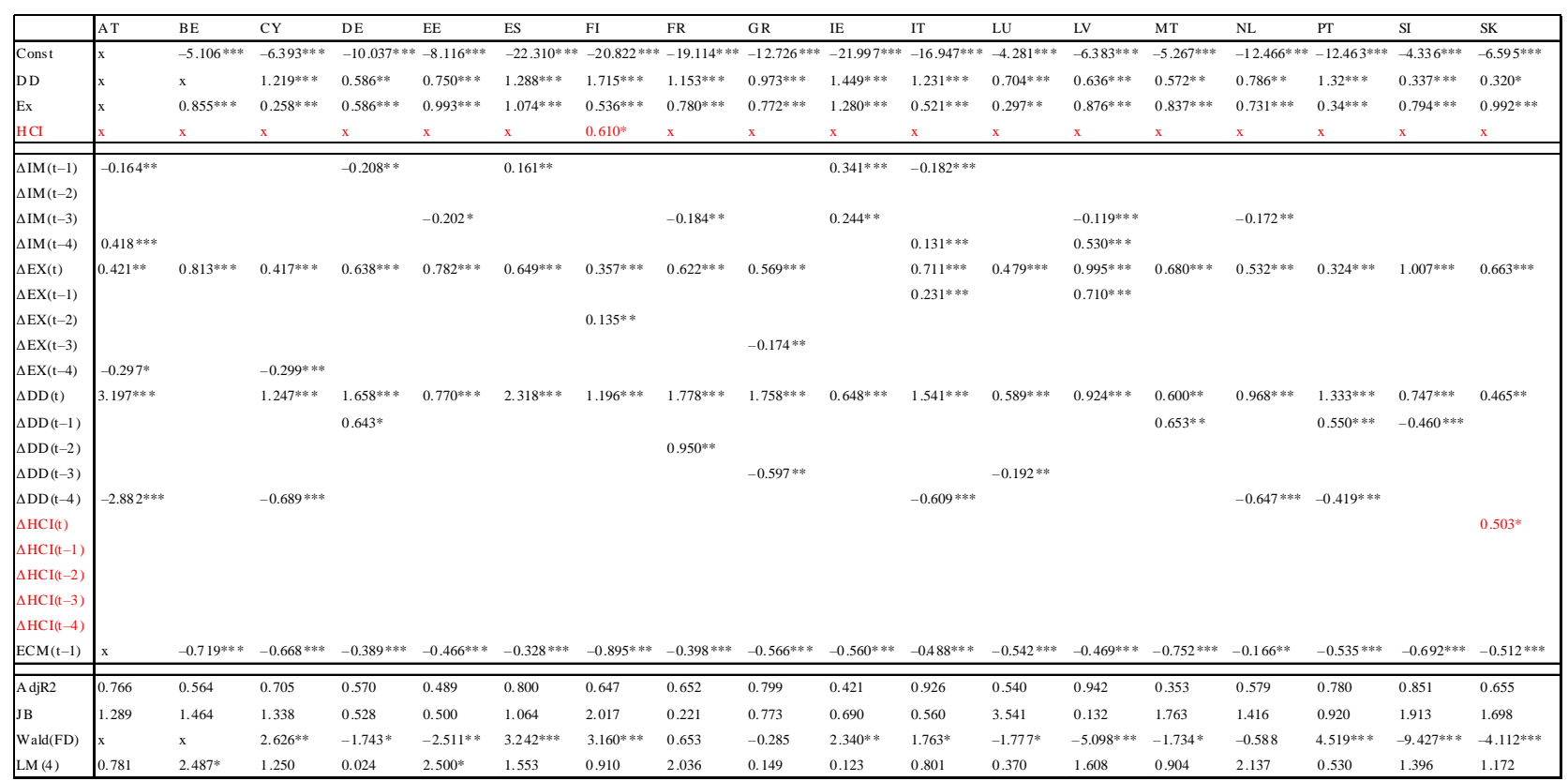

Notes: $* * *, * *$ and $*$ imply significance levels at $1 \%, 5 \%$ and $10 \%$ respectively. $\mathrm{x}$ denotes the absence of value.

Table A16

Extra-euro area import estimation results using CPI-deflated HCI

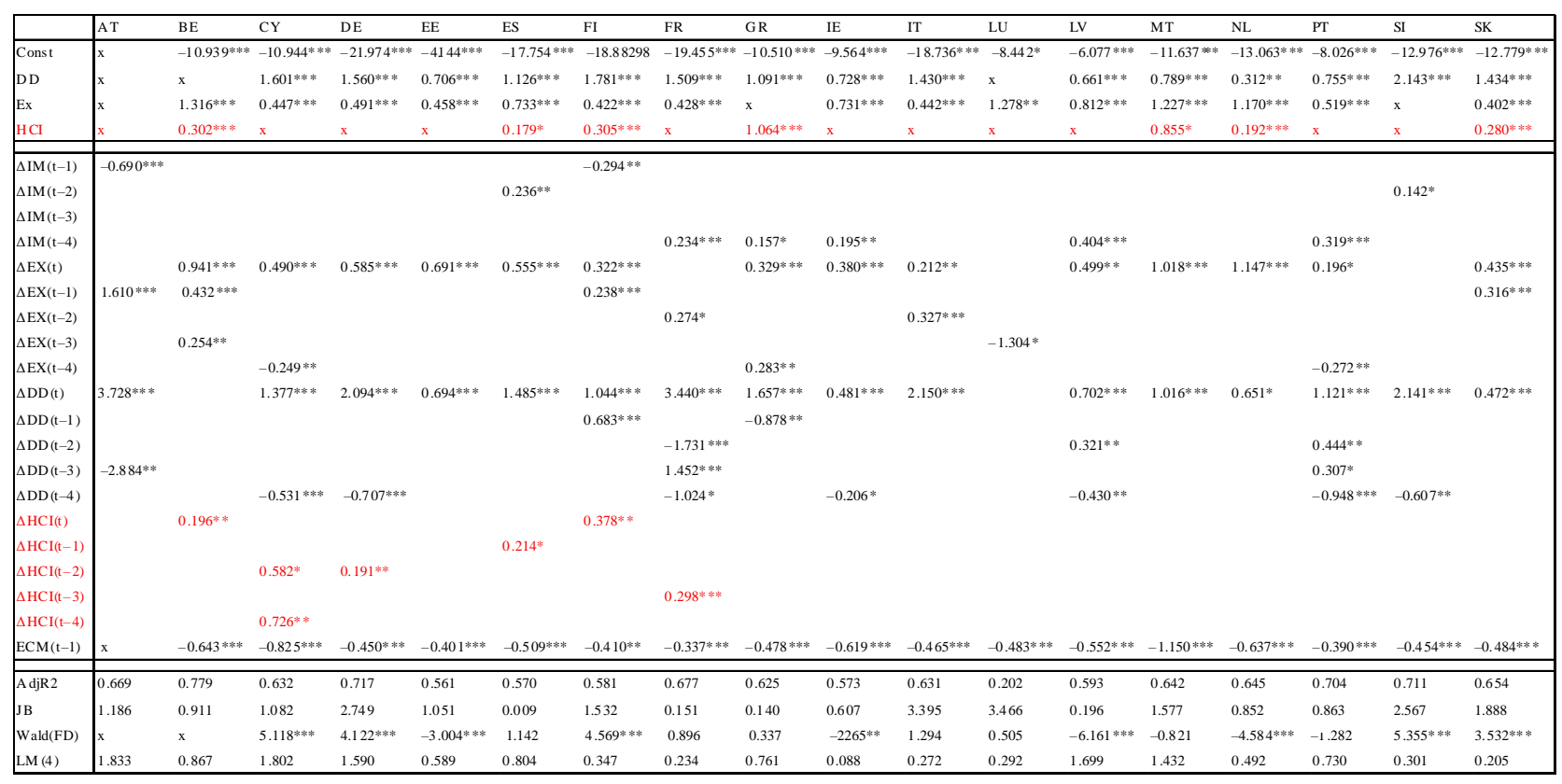

Notes: $* * *, * *$ and $*$ imply significance levels at $1 \%, 5 \%$ and $10 \%$ respectively. $\mathrm{x}$ denotes the absence of value. 
Table A17

Intra-euro area import estimation results using GDP-deflated HCI

\begin{tabular}{|c|c|c|c|c|c|c|c|c|c|c|c|c|c|c|c|c|c|c|}
\hline & $\mathrm{AT}$ & $\mathrm{BE}$ & $\mathrm{CY}$ & DE & $\mathrm{EE}$ & ES & FI & FR & GR & IE & IT & LU & LV & MT & $\mathrm{NL}$ & PT & SI & SK \\
\hline Const & $x$ & $-5.106^{* * * *}$ & $-6.393 * * * *$ & $-10.037 * * *$ & $-8.116^{* * *}$ & $-22.310^{* * * *}$ & $-18.964^{* * *}$ & $-19,114^{* * *}$ & $-12.726^{* * * *}$ & $-21.997^{* * * *}$ & $-16.947^{* * * *}$ & $-4.470^{* * * *}$ & $-6.383^{* * * *}$ & $-5.267^{* * * *}$ & $-12.466^{* * *}$ & $-15.292^{* * *}$ & $-4.336 * * * *$ & $-6.595^{* * * *}$ \\
\hline DD & $\mathrm{x}$ & $\mathrm{x}$ & $1.219^{* * * *}$ & $0.586^{* *}$ & $0.750^{* * * *}$ & $1.288^{* * * *}$ & $1.664 * * *$ & $1.153^{* * * *}$ & $0.973^{* * *}$ & $1.449 * * *$ & $1.231 * * *$ & $0.745^{* * *}$ & $0.636^{* * *}$ & $0.572^{* * *}$ & $0.786^{* * *}$ & $0.981^{* * * *}$ & $0.337^{* * *}$ & $0.320^{*}$ \\
\hline Ex & $\mathrm{x}$ & $0.855^{* * * *}$ & $0.258^{* * * *}$ & $0.586^{* * * *}$ & $0.993^{* * * *}$ & $1.074^{* * * *}$ & $0.515^{* * * *}$ & $0.780 * * * *$ & $0.772 * * *$ & $1.280^{* * * *}$ & $0.521^{* * * *}$ & $\mathrm{x}$ & $0.876^{* * * *}$ & $0.837^{* * * * *}$ & $0.731^{* * * * *}$ & $0.327 * * * *$ & $0.794 * * *$ & $0.992 * * *$ \\
\hline $\mathrm{HCl}$ & $\mathrm{x}$ & $\mathrm{x}$ & $\mathrm{x}$ & $\mathrm{x}$ & $x$ & $\mathrm{x}$ & $0.363^{*}$ & $\mathrm{x}$ & $x$ & $x$ & $x$ & $0.503^{*}$ & $\mathrm{x}$ & $x$ & $x$ & $1.421^{* * * *}$ & $x$ & $x$ \\
\hline$\Delta \mathrm{IM}(\mathrm{t}-1)$ & $-0.164^{* *}$ & & & $\begin{array}{l}-0.222^{* *} \\
\end{array}$ & & $0.161^{* *}$ & & & & $0.341^{* * * *}$ & & & & & & & & \\
\hline$\Delta \mathrm{IM}(\mathrm{t}-2)$ & & & & & & & & & & & $-0.160^{* * *}$ & & & & & & & \\
\hline$\Delta \mathrm{IM}(\mathrm{t}-3)$ & & & & & $-0.202 *$ & & & $-0.184 * *$ & & $0.244^{* * *}$ & & & $-0.119^{* * *}$ & & $-0.172^{* *}$ & & & \\
\hline$\Delta \mathrm{IM}(\mathrm{t}-4)$ & $0.418^{* * *}$ & & & & & & & & & & $0.136^{* * *}$ & & $0.530^{* * *}$ & & & & & \\
\hline$\Delta \mathrm{EX}(\mathrm{t})$ & $0.421 * *$ & $0.813^{* * *}$ & $0.407 * * *$ & $0.663^{* * * *}$ & $0.782^{* * *}$ & $0.649^{* * *}$ & $0.353^{* * * *}$ & $0.622 * * *$ & $0.569^{* * *}$ & & $0.704^{* * * *}$ & $0.479^{* * * *}$ & $0.995 * * *$ & $0.680^{* * * *}$ & $0.532^{* * * *}$ & $0.286^{* * * *}$ & $1.007 * * *$ & $0.832^{* * * *}$ \\
\hline$\Delta \operatorname{EX}(\mathrm{t}-1)$ & & & & & & & & & & & $0.222^{* * * *}$ & & $0.710^{* * * *}$ & & & & & \\
\hline$\Delta \mathrm{EX}(\mathrm{t}-2)$ & & & & & & & $0.142^{* * *}$ & & & & & & & & & & & \\
\hline$\Delta \mathrm{EX}(\mathrm{t}-3)$ & & & & & & & & & $-0.174 *$ & & & & & & & & & \\
\hline$\Delta \mathrm{EX}(\mathrm{t}-4)$ & $-0.297^{*}$ & & $-0.260^{* * * *}$ & & & & & & & & & & & & & & & \\
\hline$\Delta \mathrm{DD}(\mathrm{t})$ & 3. $197 * * * *$ & & 1. $170^{* * * *}$ & $1.832^{* * * *}$ & $0.770^{* * * *}$ & $2.318^{* * * *}$ & $1.192^{* * * *}$ & $1.778^{* * * *}$ & $1.758 * * *$ & $0.648^{* * *}$ & $1.585^{* * * *}$ & $0.528 * * *$ & $0.924 * * *$ & $0.600^{* *}$ & $0.968 * * *$ & $1.274 * * *$ & $0.747^{* * *}$ & $0.421^{* *}$ \\
\hline$\Delta \mathrm{DD}(\mathrm{t}-1)$ & & & & $0.775^{* * *}$ & & & & & & & & & & $0.653^{* *}$ & & $0.617 * * *$ & $-0.460 * * *$ & \\
\hline$\Delta \mathrm{DD}(\mathrm{t}-2)$ & & & & & & & & $0.950^{* * *}$ & & & & & & & & & & \\
\hline$\Delta \mathrm{DD}(\mathrm{t}-3)$ & & & & & & & & & $-0.597 * *$ & & & & & & & & & \\
\hline$\Delta \mathrm{DD}(\mathrm{t}-4)$ & $-2.882^{* * * *}$ & & $-0.596^{* * * *}$ & & & & & & & & -0.651 **** & & & & $-0.647^{* * * *}$ & $-0.440^{* * * *}$ & & \\
\hline$\Delta \mathrm{HCI}(\mathrm{t})$ & & & & $1.444 * *$ & & & & & & & & & & & & & & $0.847 * * *$ \\
\hline$\Delta \mathrm{HCI}(\mathrm{t}-1)$ & & & $1.975 * *$ & & & & & & & & $0.572^{*}$ & & & & & & & \\
\hline$\Delta \mathrm{HCI}(\mathrm{t}-2)$ & & & & & & & & & & & & & & & & & & \\
\hline$\Delta \mathrm{HCI}(\mathrm{t}-3)$ & & & & & & & & & & & & & & & & & & \\
\hline$\Delta \mathrm{HCI}(\mathrm{t}-4)$ & & & & & & & & & & & & $0.700^{* * *}$ & & & & & & \\
\hline $\operatorname{ECM}(t-1)$ & $x$ & $-0.719^{* * *}$ & $-0.639 * * *$ & $-0.405^{* * *}$ & $-0.466^{* * *}$ & $-0.328^{* * * *}$ & $-0.891^{* * * *}$ & $-0.398 * * *$ & $-0.566^{* * * *}$ & $-0.560^{* * * *}$ & $-0472^{* * * *}$ & $-0.545^{* * * *}$ & $-0.469 * * *$ & $-0.752 * * *$ & $-0.166^{* *}$ & $-0.395 * * *$ & $-0.692^{* * * *}$ & $-0.513^{* * * *}$ \\
\hline AdjR2 & 0.766 & 0.564 & 0.732 & 0.601 & 0.489 & 0.800 & 0.645 & 0.652 & 0.799 & 0.421 & 0.930 & 0.585 & 0.942 & 0.353 & 0.579 & 0.760 & 0.851 & 0.617 \\
\hline JB & 1.289 & 1.464 & 1. 103 & 0.070 & 0.500 & 1.064 & 1.636 & 0.221 & 0.773 & 0.690 & 0.580 & 3.532 & 0.132 & 1.763 & 1.416 & 1.160 & 1.913 & 1.820 \\
\hline Wald(FD) & $\mathrm{x}$ & $\mathrm{x}$ & $2.626^{* * *}$ & $-1.743^{*}$ & $-2.511 * *$ & $3.242 * * *$ & $3.172^{* * * *}$ & 0.653 & -0.285 & $2.340^{* * *}$ & $1.763^{*}$ & $-1.702 *$ & $-5.098^{* * * *}$ & $-1.734 *$ & -0.588 & -0.147 & $-9.427 * * *$ & $-4.112^{* * *}$ \\
\hline LM (4) & 0.781 & $2.487 *$ & 0.848 & 0.404 & $2.500^{*}$ & 1.553 & 1.054 & 2.036 & 0.149 & 0.123 & 0.741 & 0.053 & 1.608 & 0.904 & 2.137 & 0.798 & 1.396 & 0.137 \\
\hline
\end{tabular}

Notes: $* * * * *$ and $*$ imply significance levels at $1 \%, 5 \%$ and $10 \%$ respectively. $\mathrm{x}$ denotes the absence of value.

Table A18

Extra-euro area import estimation results using GDP-deflated HCI

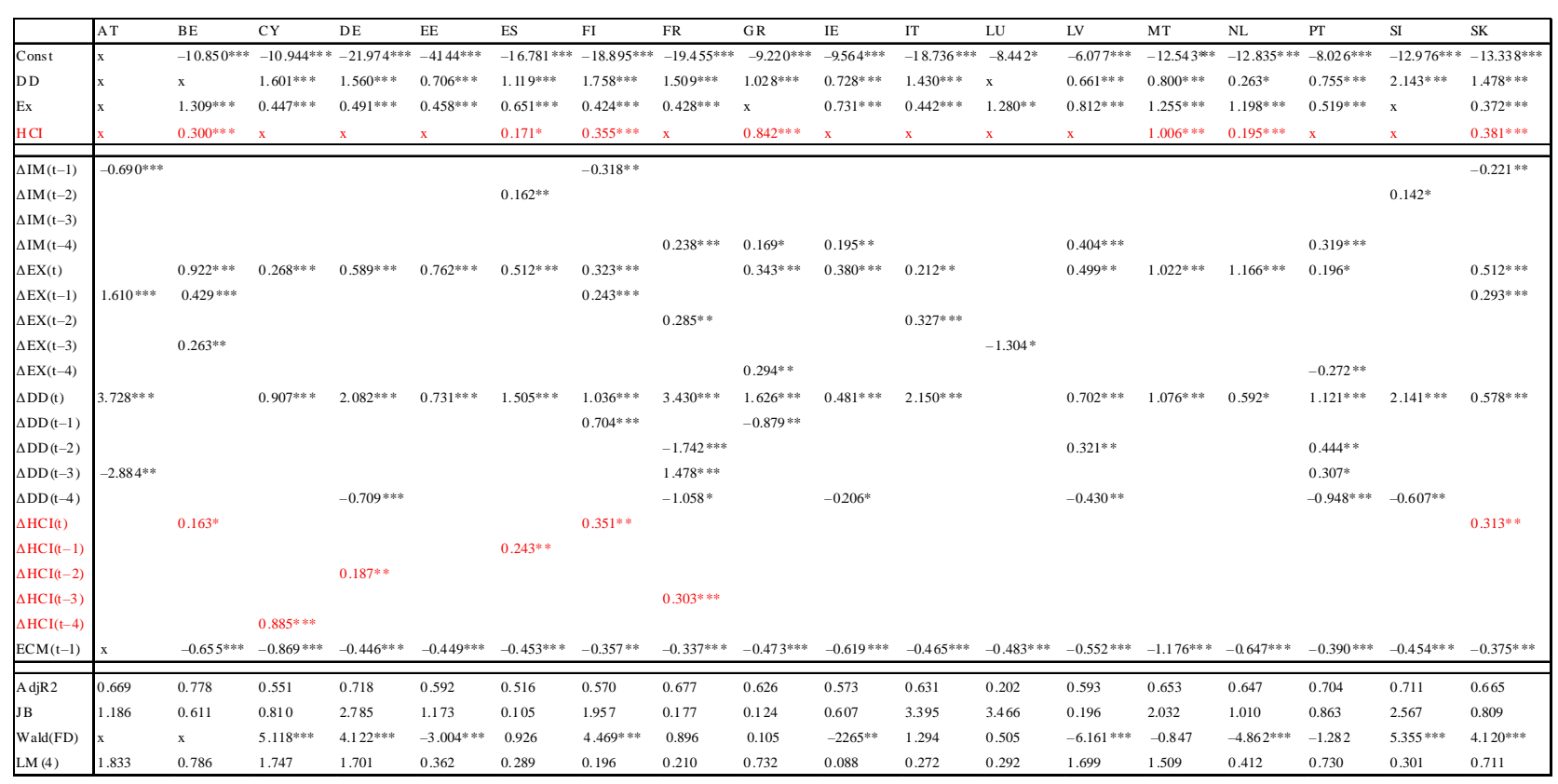

Notes: $* * *, * *$ and $*$ imply significance levels at $1 \%, 5 \%$ and $10 \%$ respectively. $\mathrm{x}$ denotes the absence of value. 
Table A19

Intra-euro area import estimation results using PPI-deflated HCI

\begin{tabular}{|c|c|c|c|c|c|c|c|c|c|c|c|c|c|c|c|c|c|c|}
\hline & $\mathrm{AT}$ & $\mathrm{BE}$ & $\mathrm{CY}$ & DE & $\mathrm{EE}$ & ES & FI & FR & GR & IE & IT & $\mathrm{LU}$ & LV & MT & $\mathrm{NL}$ & PT & SI & SK \\
\hline Const & $\mathrm{x}$ & $\begin{array}{l}-5.106^{* * * *} \\
\end{array}$ & $\begin{array}{l}-9.440^{* * * *} \\
\end{array}$ & $\begin{array}{l}-10.037 * * * \\
\end{array}$ & $-8.116^{* * * *}$ & $-22.310^{* * * * *}$ & $-15.733^{* * *}$ & $\begin{array}{l}-19,114^{* * * *} \\
\end{array}$ & $-12.726^{* * * *}$ & $-21.997^{* * * *}$ & $-16.947^{* * *}$ & $-4.281^{* * * *}$ & $\begin{array}{l}-6.383^{* * * *} \\
\end{array}$ & $\begin{array}{l}-5.267 * * * * \\
\end{array}$ & $-12.466 * * *$ & $-12.463^{* * * *}$ & 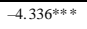 & $-6.595^{* * * *}$ \\
\hline DD & $\mathrm{x}$ & $\mathrm{x}$ & 1. $191^{1 * * *}$ & $0.586^{* *}$ & $0.750^{* * * *}$ & $1.288^{* * * *}$ & $1.486^{* * * *}$ & $1.153^{* * *}$ & $0.973^{* * *}$ & $1.449 * * *$ & $1.231^{* * * *}$ & $0.704 * * *$ & $0.636^{* * *}$ & $0.572^{* * *}$ & $0.786^{* * *}$ & $1.32^{* * * *}$ & $0.337^{* * *}$ & $0.320^{*}$ \\
\hline Ex & $x$ & $0.855^{* * * *}$ & $0.280^{* * * *}$ & $0.586^{* * * *}$ & $0.993^{* * * *}$ & $1.074^{* * * *}$ & $0.544 * * * *$ & $0.780 * * * *$ & $0.772 * * *$ & $1.280^{* * * *}$ & $0.521^{* * * *}$ & $0.297 * * *$ & $0.876 * * *$ & $0.837 * * *$ & $0.731^{* * * *}$ & $0.34 * * *$ & $0.794^{* * * *}$ & $0.992 * * *$ \\
\hline $\mathrm{HCI}$ & $\mathrm{x}$ & $x$ & $0.663 * * *$ & $\mathrm{x}$ & $x$ & $\mathrm{x}$ & $\mathrm{x}$ & $\mathrm{x}$ & $x$ & $\mathrm{x}$ & $x$ & $\mathrm{x}$ & $\mathrm{x}$ & $\mathrm{x}$ & $\mathrm{x}$ & $x$ & $x$ & $x$ \\
\hline$\Delta \mathrm{IM}(\mathrm{t}-1)$ & $-0.164^{* *}$ & & & $-0.208 * *$ & & $0.161^{* *}$ & & & & $0.341^{* * * *}$ & $-0.182 * * * *$ & & & & & & & \\
\hline$\Delta \mathrm{IM}(\mathrm{t}-2)$ & & & & & & & & & & & & & & & & & & \\
\hline$\Delta \mathrm{IM}(\mathrm{t}-3)$ & & & & & $-0.202 *$ & & & $-0.184^{* * *}$ & & $0.244^{* *}$ & & & $-0.119^{* * *}$ & & $-0.172^{* *}$ & & & \\
\hline$\Delta \mathrm{IM}(\mathrm{t}-4)$ & $0.418^{* * *}$ & & & & & & & & & & $0.131^{* * * *}$ & & $0.530^{* * * *}$ & & & & & \\
\hline$\Delta \mathrm{EX}(\mathrm{t})$ & $0.421^{* * *}$ & $0.813^{* * *}$ & $0.436 * * *$ & $0.638^{* * * *}$ & $0.782^{* * * *}$ & $0.649^{* * * *}$ & $0.343^{* * * *}$ & $0.622 * * *$ & $0.569^{* * * *}$ & & $0.711^{* * * *}$ & $0.479^{* * * * *}$ & $0.995 * * *$ & $0.680^{* * * *}$ & $0.532^{* * * *}$ & $0.318^{* * * *}$ & $0.900^{* * * *}$ & $0.746^{* * * *}$ \\
\hline$\Delta \operatorname{EX}(\mathrm{t}-1)$ & & & & & & & & & & & $0.231^{* * * *}$ & & $0.710^{* * * *}$ & & & & & \\
\hline$\Delta \mathrm{EX}(\mathrm{t}-2)$ & & & & & & & $0.123^{*}$ & & & & & & & & & & & \\
\hline$\Delta \mathrm{EX}(\mathrm{t}-3)$ & & & & & & & & & $-0.174 *$ & & & & & & & & & \\
\hline$\Delta \mathrm{EX}(\mathrm{t}-4)$ & $-0.297^{*}$ & & $-0.288^{* * * *}$ & & & & $0.110^{*}$ & & & & & & & & & & & \\
\hline$\Delta \mathrm{DD}(\mathrm{t})$ & 3. $197 * * * *$ & & $1.240^{* * * *}$ & $1.658^{* * * *}$ & $0.770^{* * * *}$ & $2.318^{* * * *}$ & $1.056^{* * * *}$ & $1.778^{* * * *}$ & $1.758^{* * * *}$ & $0.648^{* * * *}$ & $1.541^{* * * *}$ & $0.589^{* * * *}$ & $0.924 * * *$ & $0.600 * *$ & $0.968 * * *$ & $1.353^{* * * *}$ & $1.035^{* * * *}$ & $0.416^{* *}$ \\
\hline$\Delta \mathrm{DD}(\mathrm{t}-1)$ & & & & $0.643^{*}$ & & & & & & & & & & $0.653^{* * *}$ & & $0.513^{* * * *}$ & $-0.462 * *$ & \\
\hline$\Delta \mathrm{DD}(\mathrm{t}-2)$ & & & & & & & & $0.950^{* * *}$ & & & & & & & & & & \\
\hline$\Delta \mathrm{DD}(\mathrm{t}-3)$ & & & & & & & & & $-0.597 * *$ & & & $-0.192 * *$ & & & & & & \\
\hline$\Delta \mathrm{DD}(\mathrm{t}-4)$ & $-2.882^{* * * *}$ & & $-0.610^{* * * *}$ & & & & & & & & $-0.609 * * *$ & & & & $-0.647^{* * * *}$ & $-0.423 * * * *$ & & \\
\hline$\Delta \mathrm{HCI}(\mathrm{t})$ & & & & & & & & & & & & & & & & $0.313^{*}$ & & $0.905 * * *$ \\
\hline$\Delta \mathrm{HCI}(\mathrm{t}-1)$ & & & & & & & & & & & & & & & & & & \\
\hline$\Delta \mathrm{HCI}(\mathrm{t}-2)$ & & & & & & & & & & & & & & & & & & \\
\hline$\Delta \operatorname{HCI}(\mathrm{t}-3)$ & & & & & & & & & & & & & & & & & & \\
\hline$\Delta \operatorname{HCI}(\mathrm{t}-4)$ & & & & & & & & & & & & & & & & & & \\
\hline $\operatorname{ECM}(t-1)$ & $x$ & $-0.719^{* * * *}$ & $-0.811^{* * * * *}$ & $-0.389^{* * * *}$ & $-0.466^{* * * *}$ & $-0.328^{* * * *}$ & $-0.897^{* * * *}$ & $-0.398^{* * * *}$ & $-0.566^{* * * *}$ & $-0.560^{* * * *}$ & $-0.488^{* * * *}$ & $-0.542^{\text {**** }}$ & $-0.469 * * * *$ & $-0.752^{* * * *}$ & $-0.166^{* * *}$ & $-0.593^{* * * *}$ & $-0.225^{* * *}$ & $-0.485^{\text {***** }}$ \\
\hline AdjR2 & 0.766 & 0.564 & 0.742 & 0.570 & 0.489 & 0.800 & 0.663 & 0.652 & 0.799 & 0.421 & 0.926 & 0.540 & 0.942 & 0.353 & 0.579 & 0.788 & 0.733 & 0.697 \\
\hline $\mathrm{JB}$ & 1.289 & 1.464 & $4.653^{*}$ & 0.528 & 0.500 & 1.064 & 2.431 & 0.221 & 0.773 & 0.69 & 0.56 & 3.541 & 0.132 & 1.763 & 1.416 & 1.606 & 1.679 & 2.617 \\
\hline Wald(FD) & $\mathrm{x}$ & $\mathrm{x}$ & $3.225 * * *$ & $-1.743^{*}$ & $-2.511 * *$ & $3.242^{* * * *}$ & $2338^{* * *}$ & 0.653 & -0.285 & $2.340^{* *}$ & $1.763^{*}$ & $-1.777^{*}$ & $-5.098 * * *$ & $-1.734^{*}$ & -0.588 & $4.519^{* * * *}$ & $-9.427^{* * * *}$ & $-4.112^{* * * *}$ \\
\hline LM (4) & 0.781 & $2.487 *$ & 1.224 & 0.024 & $2.500^{*}$ & 1.553 & 0.783 & 2.036 & 0.149 & 0.123 & 1.093 & 0.370 & 1.608 & 0.904 & 2.137 & 0.733 & 1.238 & 0.950 \\
\hline
\end{tabular}

Notes: $* * *, * *$ and $*$ imply significance levels at $1 \%, 5 \%$ and $10 \%$ respectively. $\mathrm{x}$ denotes the absence of value.

Table A20

Extra-euro area import estimation results using PPI-deflated HCI

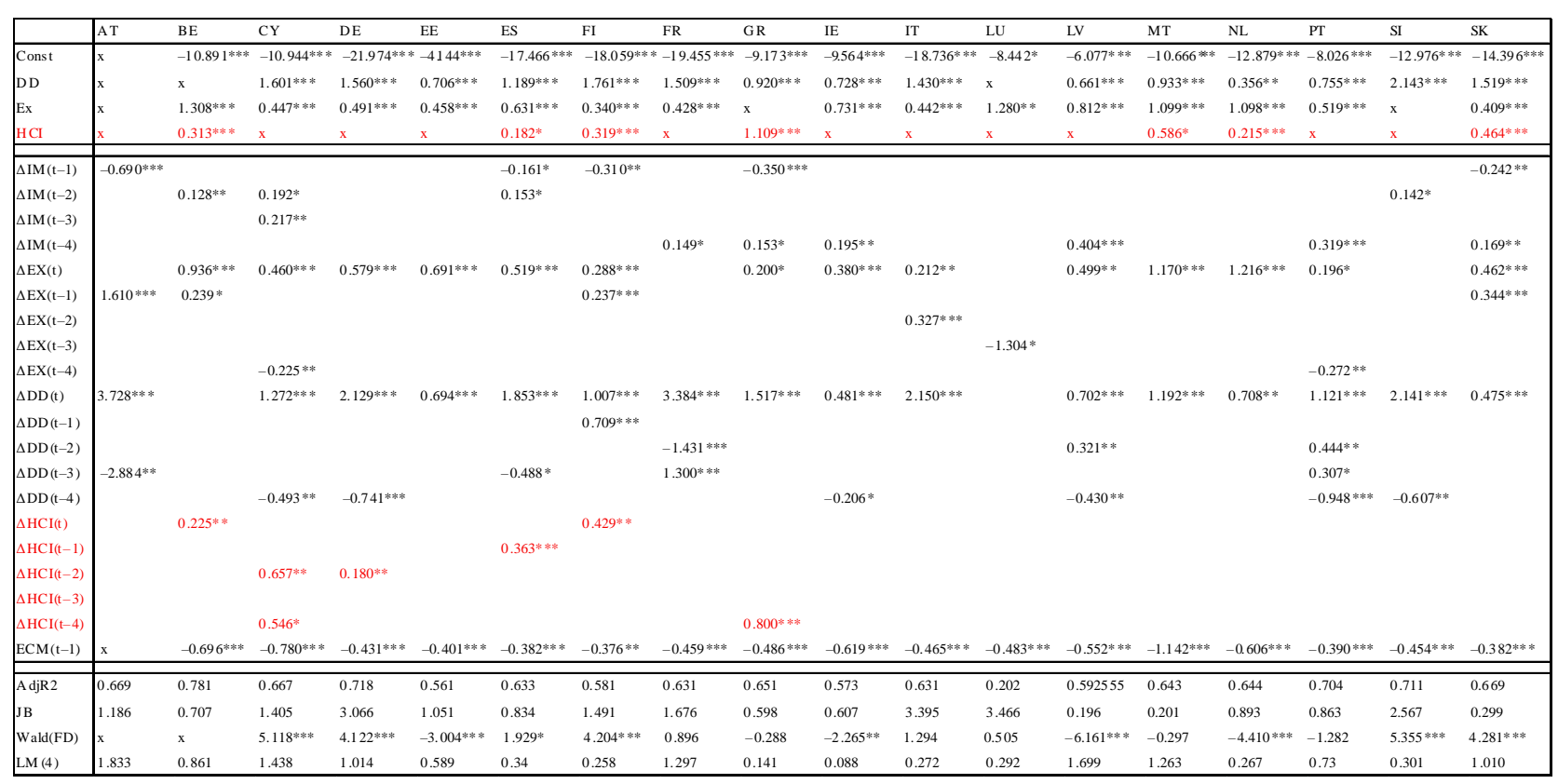

Notes: $* * *, * *$ and $*$ imply significance levels at $1 \%, 5 \%$ and $10 \%$ respectively. $\mathrm{x}$ denotes the absence of value. 
Table A21

Intra-euro area import estimation results using ULCM-deflated HCI

\begin{tabular}{|c|c|c|c|c|c|c|c|c|c|c|c|c|c|c|c|c|c|c|}
\hline & $\mathrm{AT}$ & $\mathrm{BE}$ & $\mathrm{CY}$ & DE & $\mathrm{EE}$ & ES & FI & FR & GR & IE & IT & $\mathrm{LU}$ & LV & MT & $\mathrm{NL}$ & PT & SI & SK \\
\hline Const & $-18.501^{* * *}$ & $-5.106^{* * * *}$ & $-6.393 * * * *$ & $-10.037 * * *$ & $-8.116 * * *$ & $-22.310^{* * * *}$ & $-20.229^{* * *}$ & $-19.114^{* * * *}$ & $-12.726^{* * *}$ & $-20.030^{* * * *}$ & $-16.947^{* * *}$ & $-4.281^{* * *}$ & $-6.383^{* * * *}$ & $x$ & $-12.466 * * *$ & $-11.473^{* * * *}$ & $-4.336 * * * *$ & $-6.595 * * *$ \\
\hline DD & $1.635 * * *$ & $\mathrm{x}$ & $1.219^{* * * *}$ & $0.586^{* * *}$ & $0.750^{* * * *}$ & $1.288^{* * * *}$ & $1.726^{6 * * *}$ & $1.153^{* * * *}$ & $0.973^{* * *}$ & $0.723^{* * * *}$ & $1.231^{* * * * *}$ & $0.704^{* * * *}$ & $0.636^{* * *} *$ & $0.901 * * *$ & $0.786^{* * *}$ & 1.136 *** & $0.337^{* * * *}$ & $0.320^{*}$ \\
\hline Ex & $0.278^{* * * *}$ & $0.855^{* * * *}$ & $0.258^{* * * *}$ & $0.586^{* * * *}$ & $0.993^{* * * *}$ & $1.074^{* * * *}$ & $0.569^{* * * *}$ & $0.780^{* * * *}$ & $0.772 * * *$ & $1.626^{* * *}$ & $0.521^{* * * *}$ & $0.297 * *$ & $0.876^{* * * *}$ & $\mathrm{x}$ & $0.731^{* * * *}$ & $0.212^{* * *}$ & $0.794^{* * *}$ & $0.992 * * *$ \\
\hline $\mathrm{HCl}$ & $0.531^{\mathrm{k*}}$ & $\mathrm{x}$ & $\mathrm{x}$ & $x$ & $\mathrm{x}$ & $\mathrm{x}$ & $0.374 * * *$ & $\mathrm{x}$ & $\mathrm{x}$ & $0.368^{* * *}$ & $\mathrm{x}$ & $\mathrm{x}$ & $\mathrm{x}$ & $0.895^{*}$ & $\mathrm{x}$ & $0.451^{*}$ & & \\
\hline$\Delta \mathrm{IM}(\mathrm{t}-1)$ & $-0.177^{* *}$ & & & & & $0.161^{* * *}$ & & & & $0.204^{* *}$ & $-0.182^{* * * *}$ & & & & & & & \\
\hline$\Delta \mathrm{IM}(\mathrm{t}-2)$ & & & & & & & & & & & & & & & & & & \\
\hline$\Delta \mathrm{IM}(\mathrm{t}-3)$ & & & & & $-0.202^{*}$ & & & $-0.184^{* * *}$ & & & & & $-0.119^{* * *} *$ & & $-0.172^{* * *}$ & & & \\
\hline$\Delta \mathrm{IM}(\mathrm{t}-4)$ & $0.391^{* * *}$ & & & & & & & & & & $0.131^{* * * *}$ & & $0.530^{* * *}$ & & & & & \\
\hline$\Delta \mathrm{EX}(\mathrm{t})$ & $0.469^{* * * *}$ & $0.813^{* * *}$ & $0.417^{* * * *}$ & $0.846^{* * * *}$ & $0.782^{* * * *}$ & $0.649^{* * *}$ & $0.533^{* * * *}$ & $0.622 * * *$ & $0.569^{* * * *}$ & $0.555^{* * * *}$ & $0.711^{* * * *}$ & $0.479^{* * * *}$ & $0.995^{* * * *}$ & $0.558 * * *$ & $0.532^{* * * *}$ & $0.205^{* * * *}$ & $1.007 * * *$ & $0.569^{* * * *}$ \\
\hline$\Delta \operatorname{EX}(\mathrm{t}-1)$ & & & & & & & & & & $0.471^{* * * *}$ & $0.231^{* * * *}$ & & $0.710^{* * * *}$ & & & & & $0.424 * * *$ \\
\hline$\Delta \mathrm{EX}(\mathrm{t}-2)$ & & & & & & & & & & & & & & & & $-0.129 *$ & & \\
\hline$\Delta \mathrm{EX}(\mathrm{t}-3)$ & & & & & & & & & $-0.174 * *$ & & & & & & & & & \\
\hline$\Delta \mathrm{EX}(\mathrm{t}-4)$ & $-0.288^{*}$ & & $-0.299 * * * *$ & & & & & & & & & & & & & & & \\
\hline$\Delta \mathrm{DD}(\mathrm{t})$ & 3. $168^{* * * *}$ & & $1.247^{* * * *}$ & $1.728 * * *$ & $0.770^{* * *}$ & $2.318^{* * * *}$ & $1.621^{* * * *}$ & $1.778 * * *$ & $1.758^{* * * *}$ & $0.585^{* * * *}$ & $1.541^{* * * *}$ & $0.589^{* * * *}$ & $0.924^{* * * *}$ & $0.608^{* *}$ & $0.968 * * *$ & $1.424 * * *$ & $0.747^{* * * *}$ & \\
\hline$\Delta \mathrm{DD}(\mathrm{t}-1)$ & & & & & & & & & & & & & & $0.602^{* * * *}$ & & $0.596 * * *$ & $-0.460 * * * *$ & \\
\hline$\Delta \mathrm{DD}(\mathrm{t}-2)$ & & & & & & & & $0.950^{* * *}$ & & & & & & & & & & \\
\hline$\Delta \mathrm{DD}(\mathrm{t}-3)$ & & & & & & & & & $-0.597 * *$ & & & $-0.192 * *$ & & & & & & \\
\hline$\Delta \mathrm{DD}(\mathrm{t}-4)$ & $-2.882^{* * * *}$ & & $-0.689 * * *$ & & & & & & & $-0.308^{* * *}$ & $-0.609^{* * * *}$ & & & & $-0.647^{* * * *}$ & $-0.446 * * * *$ & & \\
\hline$\Delta \mathrm{HCI}(\mathrm{t})$ & & & & $0.515^{* * * *}$ & & & & & & $0.355^{* * *}$ & & & & & & & & \\
\hline$\Delta \mathrm{HCI}(\mathrm{t}-1)$ & & & & & & & & & & & & & & & & & & \\
\hline$\Delta \mathrm{HCI}(\mathrm{t}-2)$ & & & & & & & & & & & & & & & & & & \\
\hline$\Delta \mathrm{HCI}(\mathrm{t}-3)$ & & & & & & & & & & & & & & & & & & \\
\hline$\Delta \mathrm{HCI}(\mathrm{t}-4)$ & $0.259 *$ & & & & & & & & & $0.191^{* *}$ & & & & & & & & \\
\hline $\operatorname{ECM}(t-1)$ & $\mathrm{x}$ & $-0.719^{* * * *}$ & $-0.668 * * * *$ & $-0.423^{* * *}$ & $-0.466^{* * * *}$ & $-0.328^{* * * *}$ & $-0.887 * * * *$ & $-0.398 * * *$ & $-0.566^{* * *}$ & $-0.460^{* * * *}$ & $-0488^{* * * *}$ & $-0.542^{* * * *}$ & $-0.469 * * *$ & $-0.816^{* * * *}$ & $-0.166^{* * *}$ & $-0.414 * * * *$ & $-0.692^{* * * *}$ & $-0.339 * * *$ \\
\hline AdjR2 & 0.775 & 0.564 & 0.705 & 0.610 & 0.489 & 0.800 & 0.539 & 0.652 & 0.799 & 0.588 & 0.926 & 0.540 & 0.942 & 0.483 & 0.579 & 0.772 & 0.851 & 0.852 \\
\hline $\mathrm{JB}$ & 1.137 & 1.464 & 1.338 & 1.309 & 0.500 & 1.064 & 2.650 & 0.221 & 0.773 & 0.199 & 0.560 & 3.541 & 0.132 & 1.759 & 1.416 & 0.896 & 1.913 & 0.201 \\
\hline Wald(FD) & $1.903^{*}$ & $\mathrm{x}$ & $2.626^{* *}$ & $-1.743^{*}$ & $-2.511^{* *}$ & $3.242^{* * * *}$ & $3.863^{* * * *}$ & 0.653 & -0.285 & -1.341 & $1.763^{*}$ & $-1.777^{*}$ & $-5.098 * * *$ & -0.364 & -0.588 & 1.175 & $-9.427 * * *$ & $-4.112^{* * *}$ \\
\hline LM (4) & 1.135 & $2.487 *$ & 1.250 & 0.502 & $2.500^{*}$ & 1.553 & 0.480 & 2.036 & 0.149 & 1.489 & 1.093 & 0.370 & 1.608 & 0.160 & 2.137 & 1.157 & 1.396 & 0.933 \\
\hline
\end{tabular}

Notes: $* * *, * *$ and $*$ imply significance levels at $1 \%, 5 \%$ and $10 \%$ respectively. $\mathrm{x}$ denotes the absence of value.

Table A22

Extra-euro area import estimation results using ULCM-deflated HCI

\begin{tabular}{|c|c|c|c|c|c|c|c|c|c|c|c|c|c|c|c|c|c|c|}
\hline & AT & $\mathrm{BE}$ & $\mathrm{CY}$ & DE & $\mathrm{EE}$ & ES & FI & FR & GR & IE & IT & $\mathrm{LU}$ & LV & MT & $\mathrm{NL}$ & PT & SI & SK \\
\hline Const & $x$ & $-10.803^{* * * *}$ & $-8.967^{* * * *}$ & $-21.974 * * *$ & $-4.144^{* * * *}$ & $-16.260^{* * * *}$ & $-19.960^{* * * *}$ & $-19.455^{* * *}$ & $-5.402^{* * * *}$ & $-9.564^{* * * *}$ & $-18.736 * * *$ & $-8.442^{*}$ & $-6.077^{* * * *}$ & $-10.515^{* * * k}$ & $-12.761^{* * *}$ & $-8.026^{* * * *}$ & $-12.976^{* * * *}$ & $-12.086^{* * * *}$ \\
\hline DD & $\mathrm{x}$ & $\mathrm{x}$ & $1.254 * * *$ & $1.560^{* * * *}$ & $0.706^{* * *}$ & $1.311^{\text {**** }}$ & $1.816^{* * *}$ & $1.509^{* * *}$ & $0.934^{* * *}$ & $0.728^{* * * *}$ & $1.430^{* * * *}$ & $\mathrm{x}$ & $0.661^{1 * * *}$ & $0.805^{* * *}$ & $0.349 * *$ & $0.755^{* * * *}$ & $2.143^{* * * *}$ & $1.339 * * *$ \\
\hline Ex & $\mathrm{x}$ & $1.324^{* * * *}$ & $0.372^{* * * *}$ & $0.491 * * *$ & $0.458^{* * *}$ & $0.454^{* * * *}$ & $0.516^{* * * *}$ & $0.428 * * *$ & $\mathrm{x}$ & $0.731^{* * * *}$ & $0.442^{* * * *}$ & $1.280^{* * *}$ & $0.812^{* * *}$ & $1.137 * * *$ & $1.126^{* * * *}$ & $0.519^{* * *}$ & $\mathrm{x}$ & $0.453^{* * * *}$ \\
\hline $\mathrm{HCI}$ & $x$ & $0.258^{* * * *}$ & $0.278^{*}$ & $x$ & $x$ & $\mathrm{x}$ & $0.268^{* * * *}$ & $\mathrm{x}$ & $x$ & $x$ & $x$ & $\mathrm{x}$ & $\mathrm{x}$ & $0.793 * *$ & $0.140^{* * * * *}$ & $x$ & $x$ & $0.165 * * *$ \\
\hline$\Delta \mathrm{IM}(\mathrm{t}-1)$ & $-0.690^{* * * *}$ & & & & & & & & $-0.385 * * *$ & & & & & & & & & $-0.216^{*}$ \\
\hline$\Delta \mathrm{IM}(\mathrm{t}-2)$ & & $0.118^{*}$ & $0.235 * *$ & & & $0.183^{* *}$ & $0.180^{* * *}$ & & & & & & & & & & $0.142^{*}$ & \\
\hline$\Delta \mathrm{IM}(\mathrm{t}-3)$ & & & $0.258 * *$ & & & & & & & & & & & & & & & \\
\hline$\Delta \mathrm{IM}(\mathrm{t}-4)$ & & $0.134^{* *}$ & & & & & & $0.254^{* * * *}$ & & $0.195^{* *}$ & & & $0.404^{* * * *}$ & & & $0.319^{* * * *}$ & & $0.173^{* *}$ \\
\hline$\Delta E X(t)$ & & $0.905^{* * * *}$ & $0.405 * * *$ & $0.676^{* * * *}$ & $0.691^{* * *}$ & $0.454^{* * *}$ & $0.346^{* * * *}$ & & & $0.380^{* * *}$ & $0.212^{* * *}$ & & $0.499 * *$ & $0.960^{* * * *}$ & $1.249^{* * * *}$ & $0.196^{*}$ & & $0.461^{* * * *}$ \\
\hline$\Delta \mathrm{EX}(\mathrm{t}-1)$ & $1.610^{* * *}$ & $0.329 * *$ & & & & & $0.193^{* * * *}$ & $0.244^{*}$ & & & & & & & & & & $0.358^{* * * *}$ \\
\hline$\Delta \mathrm{EX}(\mathrm{t}-2)$ & & & & $0.205^{* *}$ & & & & & & & $0.327 * * *$ & & & & & & & \\
\hline$\Delta \mathrm{EX}(\mathrm{t}-3)$ & & & & & & & & & & & & $-1.304 *$ & & & & & & \\
\hline$\Delta \mathrm{EX}(\mathrm{t}-4)$ & & & $-0.207 *$ & & & & & & & & & & & & & $-0.272^{* *}$ & & \\
\hline$\Delta \mathrm{DD}(\mathrm{t})$ & $3.728^{* * * * *}$ & & 1. $100^{* * * *}$ & $2.086^{* * * *}$ & $0.694 * * *$ & $1.503^{* * * *}$ & $1.121^{* * *}$ & $3.399 * * *$ & $1.157^{* * * *}$ & $0.481^{* * *}$ & $2.150^{* * *}$ & & $0.702 * * *$ & $1.004^{* * * *}$ & $0.668^{* * *}$ & $1.121^{* * *}$ & $2.141^{* * *}$ & $0.506^{* * * *}$ \\
\hline$\Delta \mathrm{DD}(\mathrm{t}-1)$ & & & & & & & $0.371^{* * *}$ & & & & & & & & & & & \\
\hline$\Delta \mathrm{DD}(\mathrm{t}-2)$ & & & & & & & & $-1.714 * * *$ & & & & & $0.321^{* *}$ & & & $0.444 * *$ & & \\
\hline$\Delta \mathrm{DD}(\mathrm{t}-3)$ & $-2.884^{* *}$ & & & & & & & $1.686^{* * * *}$ & & & & & & & & $0.307^{*}$ & & \\
\hline$\Delta \mathrm{DD}(\mathrm{t}-4)$ & & & $-0.510^{* *}$ & $-0.704 * * *$ & & & & $-1.014 *$ & & $-0.206 *$ & & & -0.430 ** & & & $-0.948 * * *$ & $-0.607 * *$ & \\
\hline$\Delta \mathrm{HCI}(\mathrm{t})$ & & & & $0.119^{*}$ & & & $0.258^{* * * *}$ & & & & & & & & & & & \\
\hline$\Delta \mathrm{HCI}(\mathrm{t}-1)$ & & & & & & $0.225^{* * *}$ & & & & & & & & & & & & \\
\hline$\Delta \mathrm{HCI}(\mathrm{t}-2)$ & & & & $0.202 * * *$ & & & & & & & & & & & & & & \\
\hline$\Delta \mathrm{HCI}(\mathrm{t}-3)$ & & & & & & & & $0.227^{* * *}$ & $0.394^{* * *}$ & & & & & & & & & \\
\hline$\Delta \mathrm{HCI}(\mathrm{t}-4)$ & & & & & & & & & & & & & & & & & & \\
\hline $\operatorname{ECM}(t-1)$ & $\mathrm{x}$ & $-0.677^{* * * *}$ & $-0.771^{* * * *}$ & $-0.351^{* *}$ & $-0.401 * * *$ & $-0.435 * * *$ & $-0.472^{* * * *}$ & $-0.341^{* * * *}$ & $-0.393 * * *$ & $-0.619 * * * *$ & $-0.465 * * * *$ & $-0.483^{* * * *}$ & $-0.552^{* * * *}$ & -1.147 **** & $-0.545^{* * * *}$ & $-0.390 * * *$ & $-0.454 * * * *$ & $-0.382^{* *}$ \\
\hline AdjR2 & 0.669 & 0.772 & 0.606 & 0.744 & 0.561 & 0.525 & 0.737 & 0.671 & 0.527 & 0.573 & 0.631 & 0.202 & 0.593 & 0.634 & 0.655 & 0.704 & 0.711 & 0.657 \\
\hline $\mathrm{JB}$ & 1.186 & 0.428 & 0.659 & 2.724 & 1.051 & 0.104 & 2.607 & 0.694 & 1.821 & 0.607 & 3.395 & 3.466 & 0.196 & 1.502 & 0.500 & 0.863 & 2.567 & 0.185 \\
\hline Wald(FD) & $\mathrm{x}$ & $\mathrm{x}$ & 1.177 & $4.122^{* * * *}$ & $-3.004 * * *$ & $4.078^{* * * *}$ & $3.516 * * *$ & 0.896 & -0.650 & $-2.265^{* * *}$ & 1.294 & 0.505 & $-6.161^{* * * *}$ & -0.796 & $-4.087^{* * *}$ & -1.282 & $5.355^{* * * *}$ & $3.220^{* * * *}$ \\
\hline LM (4) & 1.833 & 0.525 & 1.773 & 1.770 & 0.589 & 0.342 & 1.642 & 0.006 & 0.518 & 0.088 & 0.272 & 0.292 & 1.699 & 2.109 & 0.321 & 0.730 & 0.301 & 0.864 \\
\hline
\end{tabular}

Notes: $* * *, * *$ and $*$ imply significance levels at $1 \%, 5 \%$ and $10 \%$ respectively. $\mathrm{x}$ denotes the absence of value. 
Table A23

Intra-euro area import estimation results using ULCT-deflated HCI

\begin{tabular}{|c|c|c|c|c|c|c|c|c|c|c|c|c|c|c|c|c|c|c|}
\hline & $\mathrm{AT}$ & $\mathrm{BE}$ & $\mathrm{CY}$ & DE & $\mathrm{EE}$ & ES & FI & FR & GR & IE & IT & $\mathrm{LU}$ & LV & MT & $\mathrm{NL}$ & PT & $\mathrm{SI}$ & SK \\
\hline Const & $\mathrm{x}$ & $\begin{array}{l}-5.106^{* * * *} \\
\end{array}$ & -6.393**** & $-10.037^{* * *}$ & $-8.116^{* * * *}$ & $-22.310^{* * * *}$ & $\begin{array}{l}-19.997 * * * * \\
\end{array}$ & $-19,114^{* * *}$ & $-12.726 * * *$ & $-20.804^{* * *}$ & $-16.947^{* * *}$ & $-8.923^{* * * *}$ & $-6.383 * * *$ & $\begin{array}{l}-5.267^{* * * *} \\
\end{array}$ & $-12.466 * * *$ & $\mathrm{x}$ & $-4.336^{* * * *}$ & -6.595 **** \\
\hline DD & $\mathrm{x}$ & $\mathrm{x}$ & $1.219^{* * * *}$ & $0.586^{* *}$ & $0.750^{* * * *}$ & $1.288^{* * * *}$ & $1.816^{* * * *}$ & $1.153^{* * *}$ & $0.973^{* * *}$ & $0.938^{* * * *}$ & $1.231^{* * * *}$ & $0.716 * * *$ & $0.636^{* * *}$ & $0.572^{* * *}$ & $0.786^{* * *}$ & $1.070^{* * *}$ & $0.337^{* * *}$ & $0.320^{*}$ \\
\hline Ex & $\mathrm{x}$ & $0.855^{* * * *}$ & $0.258^{* * * *}$ & $0.586^{* * * *}$ & $0.993^{* * * *}$ & $1.074^{* * * *}$ & $0.421^{* * * *}$ & $0.780 * * * *$ & $0.772 * * *$ & $1.499^{* * * *}$ & $0.521^{* * * *}$ & $0.424 * * *$ & $0.876 * * *$ & $0.837 * * *$ & $0.731^{* * * *}$ & $0.300^{* * * *}$ & $0.794 * * * *$ & $0.992^{* * * *}$ \\
\hline $\mathrm{HCI}$ & $\mathrm{x}$ & $\mathrm{x}$ & $\mathrm{x}$ & $\mathrm{x}$ & $x$ & $\mathrm{x}$ & $0.421^{*}$ & $\mathrm{x}$ & $x$ & $0.368^{* * * *}$ & $x$ & $0.753^{* * *}$ & $\mathrm{x}$ & $x$ & $\mathrm{x}$ & $0.350 *$ & $x$ & $x$ \\
\hline$\Delta \mathrm{IM}(\mathrm{t}-1)$ & $-0.164^{* *}$ & & & & & $0.161^{* * *}$ & & & & $0.215^{* * *}$ & $-0.182 * * * *$ & & $0.087^{*}$ & & & & & \\
\hline$\Delta \mathrm{IM}(\mathrm{t}-2)$ & & & & & & & & & & & & & & & & & & \\
\hline$\Delta \mathrm{IM}(\mathrm{t}-3)$ & & & & & $-0.202 *$ & & & $-0.184^{* * *}$ & & & & & $-0.149 * * *$ & & & & & \\
\hline$\Delta \mathrm{IM}(\mathrm{t}-4)$ & $0.418^{* * *}$ & & & & & & & & & & $0.131 * * *$ & & $0.521 * * *$ & & $0.100^{*}$ & & & \\
\hline$\Delta \mathrm{EX}(\mathrm{t})$ & $0.421 * *$ & $0.813^{* * *}$ & $0.414^{* * * *}$ & $0.747 * * * *$ & $0.782^{* * * *}$ & $0.649^{* * * *}$ & $0.475^{* * * *}$ & $0.622 * * *$ & $0.569^{* * * *}$ & & $0.711^{* * * *}$ & $0.604^{* * * *}$ & $0.991^{* * * *}$ & $0.680^{* * * *}$ & $0.642 * * *$ & $0.298 * * *$ & $1.048 * * *$ & $0.876^{* * * *}$ \\
\hline$\Delta \operatorname{EX}(\mathrm{t}-1)$ & & & & & & & & & & $0.445^{* * *}$ & $0.231^{* * * *}$ & & $0.717^{* * * *}$ & & & & & \\
\hline$\Delta \mathrm{EX}(\mathrm{t}-2)$ & & & & & & & & & & & & & & & & & & \\
\hline$\Delta \mathrm{EX}(\mathrm{t}-3)$ & & & & & & & & & $-0.174 * *$ & & & $0.259^{*}$ & & & & & & \\
\hline$\Delta \mathrm{EX}(\mathrm{t}-4)$ & $-0.297^{*}$ & & $-0.298^{* * * *}$ & & & & & & & & & & & & & & & \\
\hline$\Delta \mathrm{DD}(\mathrm{t})$ & 3. $197 * * *$ & & $1.248^{* * * *}$ & $1.265^{* * * *}$ & $0.770^{* * * *}$ & $2.318^{* * * *}$ & $1.073^{* * * *}$ & $1.778^{* * * *}$ & $1.758^{* * * *}$ & $0.590^{* * * *}$ & $1.541^{* * * *}$ & $0.607^{* * * *}$ & $1.012^{* * * *}$ & $0.600 * *$ & $1.137 * * *$ & $1.261^{* * *}$ & $0.656^{* * * *}$ & $0.567^{* * * *}$ \\
\hline$\Delta \mathrm{DD}(\mathrm{t}-1)$ & & & & & & & $-0.614^{* * *}$ & & & & & & & $0.653^{* * *}$ & & $0.607^{* * *}$ & $-0.418^{* *}$ & \\
\hline$\Delta \mathrm{DD}(\mathrm{t}-2)$ & & & & & & & & $0.950^{* * *}$ & & $0.454^{* * * *}$ & & & & & & & & \\
\hline$\Delta \mathrm{DD}(\mathrm{t}-3)$ & & & & & & & & & $-0.597 * *$ & & & $-0.193 * *$ & & & & & & \\
\hline$\Delta \mathrm{DD}(\mathrm{t}-4)$ & $-2.882^{* * *}$ & & $-0.726 * * * *$ & & & & & & & & $-0.609 * * *$ & & & & $-0.714 * * *$ & $-0.349 * *$ & & \\
\hline$\Delta \mathrm{HCI}(\mathrm{t})$ & & & & $1.077 * * *$ & & & & & & & & & & & & & & $0.881 * * *$ \\
\hline$\Delta \mathrm{HCI}(\mathrm{t}-1)$ & & & $0.882^{*}$ & & & & & & & & & & & & & & & \\
\hline$\Delta \mathrm{HCI}(\mathrm{t}-2)$ & & & & & & & & & & & & & & & & & $0.623^{*}$ & \\
\hline$\Delta \mathrm{HCI}(\mathrm{t}-3)$ & & & & & & & & & & & & & $0.365^{* * *}$ & & & & & \\
\hline$\Delta \mathrm{HCI}(\mathrm{t}-4)$ & & & & & & & & & & & & & & & $0.723 * *$ & & & \\
\hline $\operatorname{ECM}(t-1)$ & $x$ & $-0.719^{* * * *}$ & $-0.642 * * * *$ & $-0.424 * * *$ & $-0.466 * * *$ & $-0.328^{* * * *}$ & $-0.981^{* * * *}$ & $-0.398 * * *$ & $-0.566^{* * * *}$ & $-0.557 * * * *$ & $-0488 * * *$ & $-0.633 * * *$ & $-0.563^{* * * *}$ & $-0.752^{* * * *}$ & $-0.203^{* * * *}$ & $-0.542 * * *$ & $-0.641^{* * * *}$ & $-0.490^{* * * *}$ \\
\hline AdjR2 & 0.766 & 0.564 & 0.722 & 0.557 & 0.489 & 0.800 & 0.625 & 0.652 & 0.799 & 0.507 & 0.926 & 0.596 & 0.950 & 0.353 & 0.472 & 0.784 & 0.859 & 0.682 \\
\hline $\mathrm{JB}$ & 1.289 & 1.464 & 1.810 & 1.723 & 0.500 & 1.064 & 1.852 & 0.221 & 0.773 & 0.301 & 0.560 & 4.136 & 1.574 & 1.763 & 2.431 & 1.137 & 1.460 & 1.383 \\
\hline Wald(FD) & $\mathrm{x}$ & $\mathrm{x}$ & $2.626^{* *}$ & $-1.743^{*}$ & $-2.511^{* *}$ & $3.242 * * *$ & $4.808^{* * * *}$ & 0.653 & -0.285 & -0.385 & $1.763^{*}$ & $-1.916^{*}$ & $-5.098^{* * *}$ & $-1.734^{*}$ & -0.588 & 0.620 & $-9.427^{* * * *}$ & $-4.112 * * *$ \\
\hline LM (4) & 0.781 & $2.487 *$ & 0.832 & 1.607 & $2.500^{*}$ & 1.553 & 1.854 & 2.036 & 0.149 & 1.279 & 1.093 & 1.211 & 0.407 & 0.904 & 0.662 & 0.689 & 1.194 & 0.867 \\
\hline
\end{tabular}

Notes: $* * *, * *$ and $*$ imply significance levels at $1 \%, 5 \%$ and $10 \%$ respectively. $\mathrm{x}$ denotes the absence of value.

Table A24

Extra-euro area import estimation results using ULCT-deflated HCI

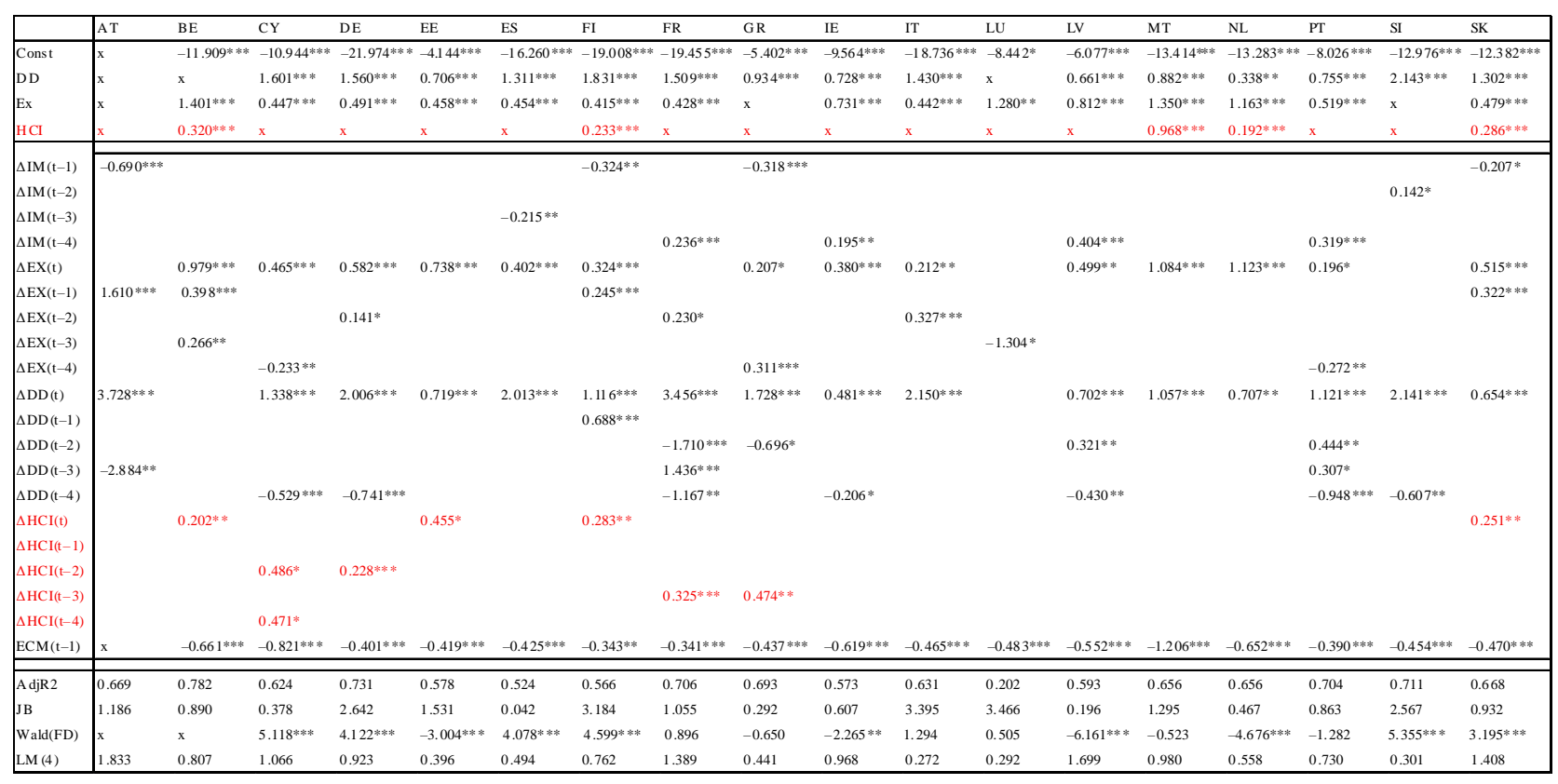

Notes: $* * *, * *$ and $*$ imply significance levels at $1 \%, 5 \%$ and $10 \%$ respectively. $\mathrm{x}$ denotes the absence of value. 


\section{REFERENCES}

ALTOMONTE, Carlo, OTTAVIANO, Gianmarco (2009). Resilient to the Crisis? Global Supply Chains and Trade Flows. In: The Great Trade Collapse: Causes, Consequences and Prospects. E-book, edited by R. Baldwin. Section II, Chapter 11.

AMADOR, João, CAPPARIELLO, Rita, STEHRER, Robert (2015). Global Value Chains: A View from the Euro Area. Asian Economic Journal, vol. 29, issue 2, June 2015, pp. 99-120.

ANDERTON, Robert, BALTAGI, Badi H., SKUDELNY, Frauke, SOUSA, Nuno (2005). Intra- and Extra-Euro Area Import Demand for Manufactures. ECB Working Paper, No. 532, October 2005. 36 p.

BARRELL, Ray, DÉES, Stephane (2005). World Trade and Global Integration in Production Processes: A Re-Assessment of Import Demand Equations. ECB Working Paper, No. 503, July 2005. 38 p.

BARRELL, Ray, te VELDE, Dirk W. (2002). European Integration and Manufactures Import Demand: An Empirical Investigation of Ten European Countries. German Economic Review, vol. 3, issue 3, August 2002, pp. 263-293.

BAYOUMI, Tamim, HARMSEN, Richard, TURUNEN, Jarkko (2011). Euro Area Export Performance and Competitiveness. IMF Working Paper, No. 11/140, June 2011. 17 p.

BERNARDI, Luigi (2013). Recent Findings Regarding the Shift from Direct to Indirect Taxation in the EA-17. MPRA Paper, No. 47877, June 2013. 23 p.

BERTHOU, Antoine, DEMIAN, Vlad, DHYNE, Emmanuel (2015). Exchange Rate Movements, Firm-Level Exports and Heterogeneity. Presentation at the CompNet conference, Frankfurt, 25-26 June 2015 [viewed 15 August 2016]. Available

from: https://www.ecb.europa.eu/home/pdf/research/compnet/20150625/4a_Exchange _rate_movements_firm_level_exports_and_heterogeneity.pdf?f433ec9a9de6e170 c055bdb813c5c1d6.

BLANCHARD, Olivier J., GIAVAZZI, Francesco (2002). Current Account Deficits in the Euro Area: The End of the Feldstein-Horioka Puzzle? Brookings Papers on Economic Activity, vol. 33, issue 2, pp. 147-210.

BOBEICA, Elena, ESTEVES, Paolo S., RUA, António, STAEHR, Karsten (2016). Exports and Domestic Demand Pressure: A Dynamic Panel Data Model for the Euro Area Countries. Review of World Economics, vol. 152, issue 1, February 2016, pp. 107-125.

BUSSIÈRE, Matthieu, CALLEGARI, Giovanni, GHIRONI, Fabio, SESTIERI, Giulia, YAMANO, Norihiko (2013). Estimating Trade Elasticities: Demand Composition and the Trade Collapse of 2008-2009. American Economic Journal: Macroeconomics, vol. 5, No. 3, pp. 118-151. 
CA' ZORZI, Michele, SCHNATZ, Bernd (2007). Explaining and Forecasting Euro Area Exports: Which Competitiveness Indicator Performs Best? ECB Working Paper, No. 833, November 2007. 31 p.

CHRISTODOULOPOULOU, Styliani, TKAČEVS, Oḷegs (2016). Measuring the Effectiveness of Cost and Price Competitiveness in External Rebalancing of Euro Area Countries: What Do Alternative HCIs Tell Us? Empirica, vol. 43, issue 3, August 2016, pp. 487-531.

CLOSTERMANN, Jörg (1998). What is the Fittest Price Measure for the Calculation of Real D-Mark Exchange Rates? Ifo Studien, No. 44, issue 4, pp. 393-412.

Deutsche Bundesbank (1998). The Indicator Quality of Different Definitions of the Real External Value of the Deutsche Mark. Deutsche Bundesbank Monthly Report, November 1998, pp. 39-52.

DIEPPE, Alistair, WARMEDINGER, Thomas (2007). Modelling Intra- and Extra-Area Trade Substitution and Exchange Rate Pass-Through in the Euro Area. ECB Working Paper, No. 760, June 2007. 59 p.

ECB (2012). Longer-Term Developments in Extra-Euro Area and Intra-Euro Area Trade. ECB Monthly Bulletin, Box 9, March 2012, pp. 81-84.

ECB (2013). Intra-Euro Area Trade Linkages and External Adjustment. ECB Monthly Bulletin, January 2013, pp. 59-74.

ESTEVES, Paulo, RUA, António (2013). Is There a Role for Domestic Demand Pressure on Export Performance? ECB Working Paper, No. 1594, September 2013. $31 \mathrm{p}$.

ESTRADA, Ángel, FERNÁNDEZ, José L., MORAL, Esther, REGIL, Ana (2004). A Quarterly Macroeconometric Model of the Spanish Economy. Banco de Espana Working Paper, No. 0413. 60 p.

European Commission (2015). Annual Growth Survey 2016: Strengthening the Recovery and Fostering Convergence. 26 November 2015. 4 p.

FRANKEL, Jeffrey A., ROSE, Andrew K. (1998). The Endogeneity of the Optimum Currency Area Criteria. Economic Journal, vol. 108, issue 449, July 1998, pp. 1009-1025.

GIORDANO, Claire, ZOLLINO, Francesco (2015). Exploring Price and NonPrice Determinants of Trade Flows in the Largest Euro Area Countries. ECB Working Paper, No. 1789, May 2015. 35 p.

HUBRICH, Kirstin, KARLSSON, Tohmas (2010). Trade Consistency in the Context of the Eurosystem Projection Exercises. ECB Occasional Paper, No. 108, March 2010. 49 p.

KANG, Joong S., SHAMBAUGH, Jay C. (2015). The Rise and Fall of European Current Account Deficits. 61st Economic Policy Panel Meeting in Riga, 17-18 April 2015. 
KARADELOGLOU, Pavlos, BENKOVSKIS, Konstantins, AIELLO, Giovanni, BLUHM, Benjamin, BOBEICA, Elena, BUELENS, Christian, CAVALLINI, Flavia, CHRISTODOULOPOULOU, Styliani, De CLERCQ, Maarten, GIORDANO, Claire, JOSEPH, Andreas, LEONTE, Alexandru, LOMMATZSCH, Kirsten, LOPEZ-GARCIA, Paloma, MOMCHILOV, Georgi, OSBAT, Chiara, ORSZAGHOVA, Lucia, PAPPADÀ, Francesco, PRADES ILLANES, Elvira, SILGONER, Maria, TKACEVS, Olegs, VERMEULEN, Robert, WÖRZ, Julia, ZOLLINO, Francesco (2015). Compendium on the Diagnostic Toolkit for Competitiveness. ECB Occasional Paper, No. 163, July 2015.83 p.

LOPEZ-GARCIA, Paloma, di MAURO, Filippo, the CompNet Task Force (2015). Assessing European Competitiveness: The New CompNet Microbased Database. ECB Working Paper, No. 1764, March 2015. 63 p.

MARSH, Ian W., TOKARICK, Stephen P. (1996). An Assessment of Three Measures of Competitiveness. Review of World Economics (Weltwirtschaftliches Archiv), vol. 132, issue 4, pp. 700-722.

PLUYAUD, Bertrand (2006). Modelling Imports and Exports of Goods in France, Distinguishing between Intra- and Extra-Euro Area Trade. In: Convergence or Divirgence in Europe?: Growth and Business Cycles in France, Germany and Italy. Ed. by O. De Bandt, H. Herrmann, G. Parigi. Berlin: Springer, pp. 325-359.

SCHMITZ, Martin, De CLERCQ, Maarten, FIDORA, Michael, LAURO, Bernadette, PINHEIRO, Cristina (2012). Revisiting the Effective Exchange Rates of the Euro. ECB Occasional Paper, No. 134, June 2012. 39 p.

STAHN, Kerstin (2006). Has the Impact of Key Determinants of German Exports Changed? Results from Estimations of Germany's Intra Euro-Area and Extra Euro-Area Exports. Deutsche Bundesbank Discussion Paper, Series 1: Economic Studies, No. 07/2006. 44 p.

STIRBÖCK, Claudia (2006). How Strong is the Impact of Exports and Other Demand Components on German Import Demand? Evidence from Euro-Area and Non-Euro-Area Imports. Deutsche Bundesbank Discussion Paper, Series 1: Economic Studies, No. 39/2006. 72 p.

TRESSEL, Thierry, WANG, Shengzu (2014). Rebalancing in the Euro Area and Cyclicality of Current Account Adjustments. IMF Working Paper, No. 14/130, July 2014. $31 \mathrm{p}$. 